National Water-Quality Assessment Program

\title{
Water Quality at Fixed Sites in the Great Salt Lake Basins, Utah, Idaho, and Wyoming, Water Years 1999-2000
}

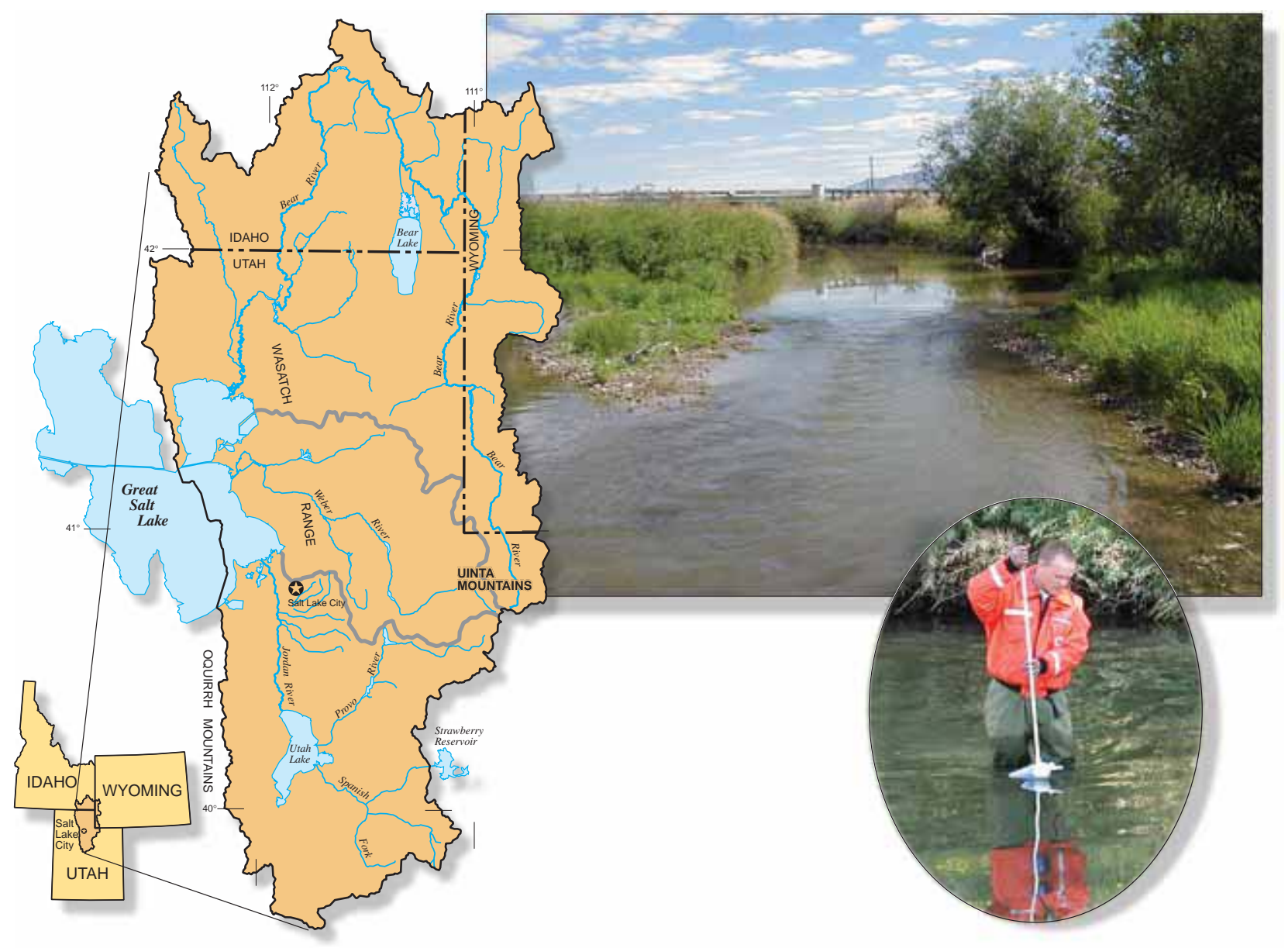

Water-Resources Investigations Report 03-4236 


\section{Water Quality at Fixed Sites in the Great Salt Lake Basins, Utah, Idaho, and Wyoming, Water Years 1999-2000}

By Steven J. Gerner

U.S. Geological Survey

WATER-RESOURCES INVESTIGATIONS REPORT 03-4236

NATIONAL WATER-QUALITY ASSESSMENT PROGRAM

Salt Lake City, Utah 


\section{U.S. DEPARTMENT OF THE INTERIOR}

GALE A. NORTON, Secretary

\section{U.S. GEOLOGICAL SURVEY}

Charles G. Groat, Director

Any use of trade, product, or firm names in this publication is for descriptive purposes only and does not imply endorsement by the U.S. Government.

For additional information write to:

Copies of this report can be purchased from:

District Chief

U.S. Geological Survey

2329 West Orton Circle

Salt Lake City, UT 84119

http://ut.water.usgs.gov
U.S. Geological Survey

Branch of Information Services

Building 810

Box 25286, Federal Center

Denver, CO 80225-0286 


\section{FOREWORD}

The U.S. Geological Survey (USGS) is committed to serve the Nation with accurate and timely scientific information that helps enhance and protect the overall quality of life, and facilitates effective management of water, biological, energy, and mineral resources (http://www.usgs.gov/). Information on the quality of the Nation's water resources is of critical interest to the USGS because it is so integrally linked to the long-term availability of water that is clean and safe for drinking and recreation and that is suitable for industry, irrigation, and habitat for fish and wildlife. Escalating population growth and increasing demands for the multiple water uses make water availability, now measured in terms of quantity and quality, even more critical to the long-term sustainability of our communities and ecosystems.

The USGS implemented the National Water-Quality Assessment (NAWQA) program to support national, regional, and local information needs and decisions related to water-quality management and policy (http://water.usgs.gov/nawqa). Shaped by and coordinated with ongoing efforts of other Federal, State, and local agencies, the NAWQA program is designed to answer: What is the condition of our Nation's streams and ground water? How are the conditions changing over time? How do natural features and human activities affect the quality of streams and ground water, and where are those effects most pronounced? By combining information on water chemistry, physical characteristics, stream habitat, and aquatic life, the NAWQA program aims to provide sciencebased insights for current and emerging water issues and priorities. NAWQA results can contribute to informed decisions that result in practical and effective water-resource management and strategies that protect and restore water quality.

Since 1991, the NAWQA program has implemented interdisciplinary assessments in more than 50 of the Nation's most important river basins and aquifers, referred to as Study Units (http://water.usgs.gov/nawqa/ nawqamap.html). Collectively, these Study Units account for more than 60 percent of the overall water use and population served by public water supply, and are representative of the Nation's major hydrologic landscapes, priority ecological resources, and agricultural, urban, and natural sources of contamination.

Each assessment is guided by a nationally consistent study design and methods of sampling and analysis. The assessments thereby build local knowledge about water-quality issues and trends in a particular stream or aquifer while providing an understanding of how and why water quality varies regionally and nationally. The consistent, multi-scale approach helps to determine if certain types of water-quality issues are isolated or pervasive, and allows direct comparisons of how human activities and natural processes affect water quality and ecological health in the Nation's diverse geographic and environmental settings. Comprehensive assessments on pesticides, nutrients, volatile organic compounds, trace metals, and aquatic ecology are developed at the national scale through comparative analysis of the Study-Unit findings (http://water.usgs.gov/nawqa/natsyn.html).

The USGS places high value on the communication and dissemination of credible, timely, and relevant science so that the most recent and available knowledge about water resources can be applied in management and policy decisions. We hope this NAWQA publication will provide you the needed insights and information to meet your needs, and thereby foster increased awareness and involvement in the protection and restoration of our Nation's waters.

The NAWQA program recognizes that a national assessment by a single program cannot address all waterresource issues of interest. External coordination at all levels is critical for a fully integrated understanding of watersheds and for cost-effective management, regulation, and conservation of our Nation's water resources. The program, therefore, depends extensively on the advice, cooperation, and information from other Federal, State, interstate, Tribal, and local agencies, non-government organizations, industry, academia, and other stakeholder groups. The assistance and suggestions of all are greatly appreciated.

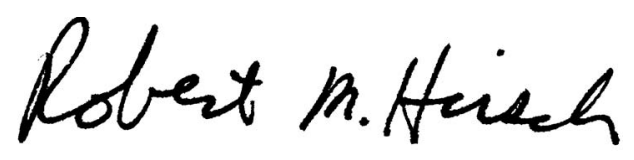

Robert M. Hirsch

Associate Director for Water 


\section{CONTENTS}

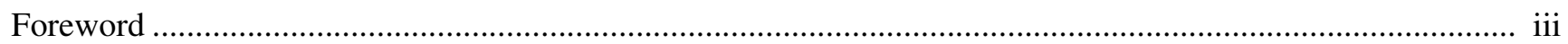

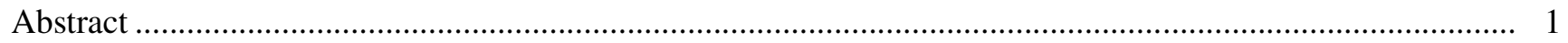

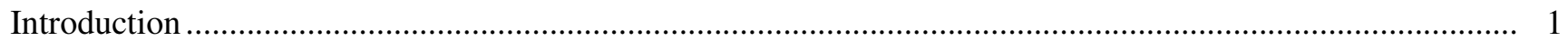

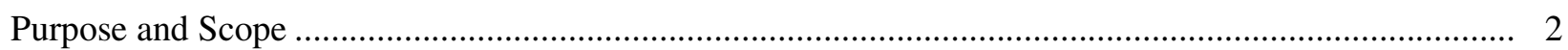

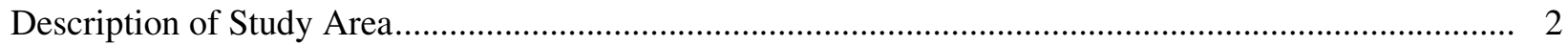

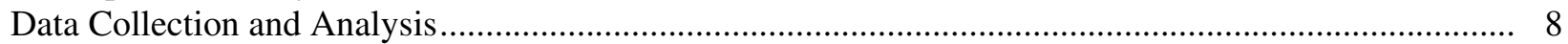

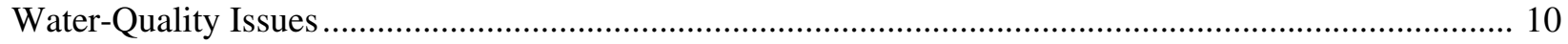

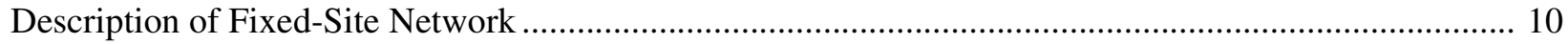

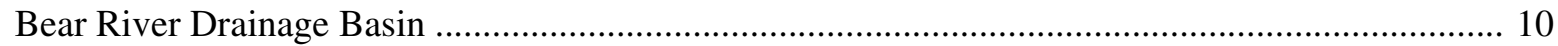

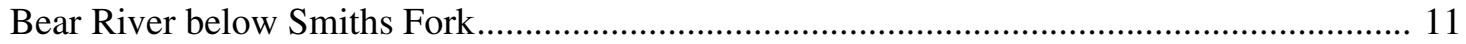

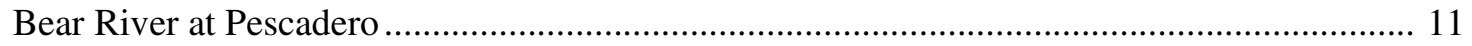

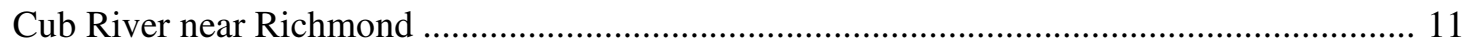

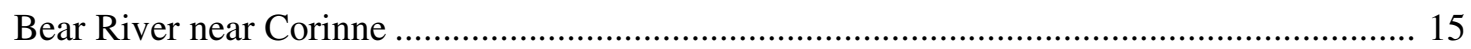

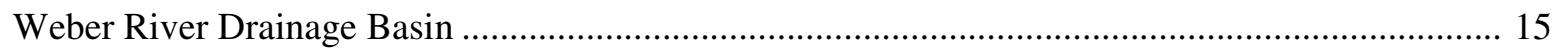

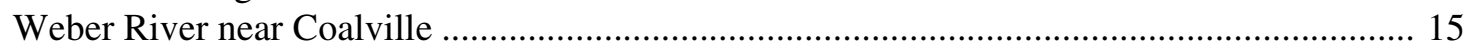

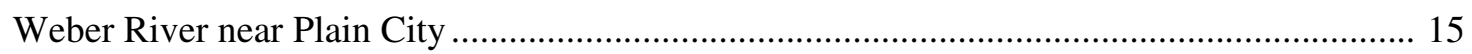

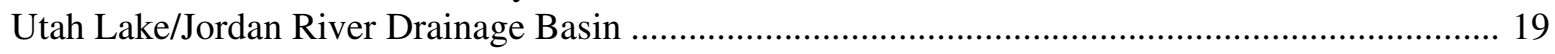

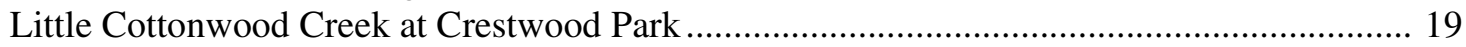

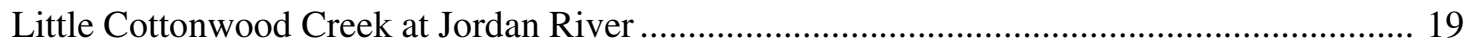

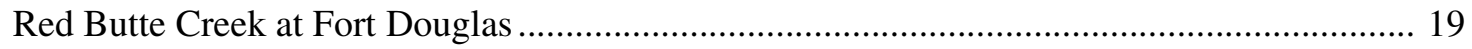

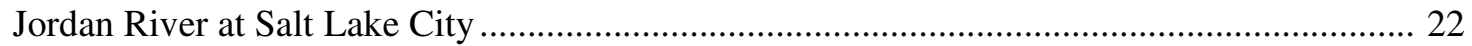

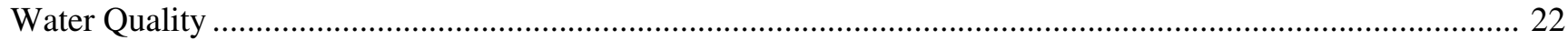

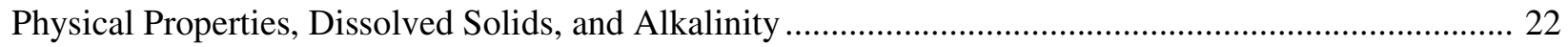

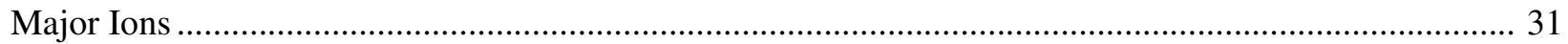

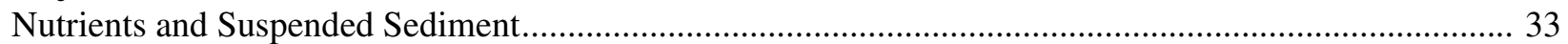

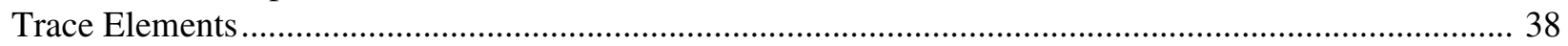

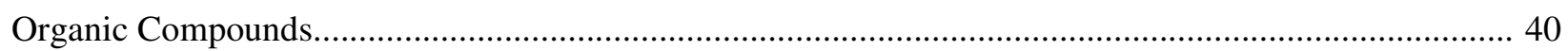

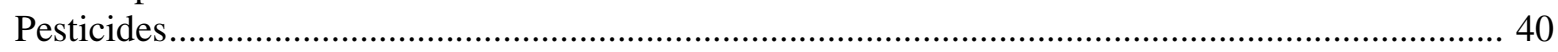

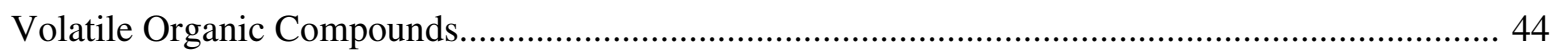

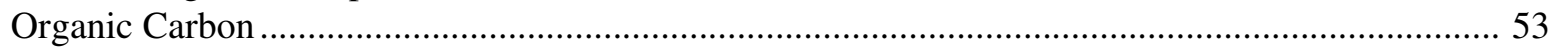

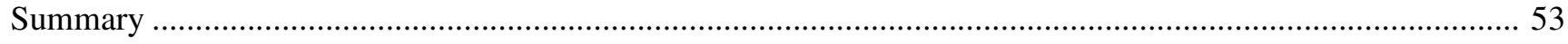

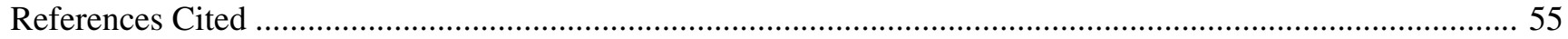




\section{FIGURES}

Figure 1. Map showing location of fixed sites in the Great Salt Lake Basins study unit ........................... 3

Figure 2. Map showing physiographic provinces of the Great Salt Lake Basins study unit.......................... 4

Figure 3. Map showing ecoregions of the Great Salt Lake Basins study unit. Data from Omernik, 1987 ...... 5

Figure 4. Graphs showing departure of monthly precipitation from 1971-2000 average at Salt Lake City National Weather Service Forecast Office, Utah, and Silver Lake near Brighton, Utah,

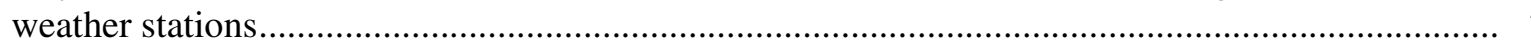

Figure 5. Land use/land cover, drainage basin location, and streamflow for the Bear River below Smiths Fork, near Cokeville, Wyoming

Figure 6. Land use/land cover, drainage basin location, and streamflow for the Bear River at Pescadero,

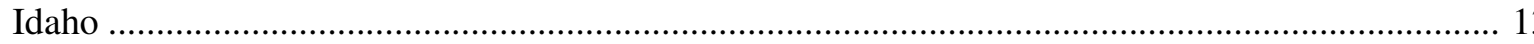

Figure 7. Land use/land cover, drainage basin location, and streamflow for the Cub River near Richmond,

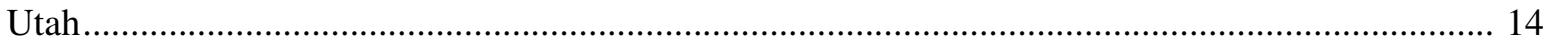

Figure 8. Land use/land cover, drainage basin location, and streamflow for the Bear River near Corinne, Utah.

Figure 9. Land use/land cover, drainage basin location, and streamflow for the Weber River near Coalville, Utah

Figure 10. Land use/land cover, drainage basin location, and streamflow for the Weber River near Plain City, Utah

Figure 11. Land use/land cover, drainage basin location, and streamflow for Little Cottonwood Creek at Crestwood Park, Salt Lake City, Utah.....

Figure 12. Land use/land cover, drainage basin location, and streamflow for Little Cottonwood Creek at Jordan River, Salt Lake City, Utah

Figure 13. Land use/land cover, drainage basin location, and streamflow for Red Butte Creek at Fort Douglas, near Salt Lake City, Utah

Figure 14. Land use/land cover, drainage basin location, and streamflow for the Jordan River at Salt Lake City, Utah

Figure 15. Boxplots showing specific-conductance value, $\mathrm{pH}$, alkalinity, and dissolved oxygen in water samples from fixed sites in the Great Salt Lake Basins study unit.....

Figure 16. Boxplots showing range and distribution of dissolved solids in water samples from fixed sites during (A) November through February, (B) March through June, (C) July through October, and (D) January through December, Great Salt Lake Basins study unit

Figure 17. Graph showing dissolved-solids concentration and streamflow at site 8, Little Cottonwood Creek at Jordan River, Salt Lake City, Utah.

Figure 18. Graphs showing Daily mean water temperature at fixed sites in the Great Salt Lake Basins study unit.....

Figure 19. Diagrams showing chemical composition of water samples collected during winter base flow, snowmelt, and summer base flow conditions at fixed sites in the Great Salt Lake Basins study unit, 1999 water year....

Figure 20. Boxplot showing molar ratio of potassium to sodium in water samples from fixed sites in the Great Salt Lake Basins study unit

Figure 21. Boxplots showing concentration of suspended sediment, percentage of particulate phosphorus, and different forms of phosphorus and nitrogen in water samples from fixed sites in the Great Salt Lake Basins study unit. 
Figure 22. Graphs showing concentration of dissolved and particulate nitrogen in water samples from fixed sites in the Great Salt Lake Basins study unit, January, March, May, and July 2000

Figure 23. Graph showing concentration of total phosphorus in relation to suspended sediment in water samples from fixed sites 1 and 10 in the Great Salt Lake Basins study unit

Figure 24. Boxplots showing concentration of selected trace elements in water samples from fixed sites in the Great Salt Lake Basins study unit

Figure 25. Map showing National Water-Quality Assessment program study units with pesticide and volatile organic compound concentration data, water years 1999-2000.

Figure 26. Graphs showing detection frequency, based on a common reporting limit of 0.05 microgram per liter, of pesticides in water samples analyzed by gas chromatography/mass spectrometry from agricultural, urban, and mixed-land-use sites in the Great Salt Lake Basins study unit and at sites with similar land uses in study units across the Nation, water years 1999-2000.

Figure 27. Graphs showing ninetieth-percentile concentration of pesticides detected in water samples analyzed by gas chromatography/mass spectrometry from agricultural, urban, and mixedland-use sites in the Great Salt Lake Basins study unit and sites with similar land uses in study units across the Nation, water years 1999-2000.

Figure 28. Graphs showing detection frequency, based on a common reporting limit of 0.2 microgram per liter, of volatile organic compounds in water samples from urban and mixed-land-use sites in the Great Salt Lake Basins study unit and at sites with similar land uses in study units across the Nation, water years 1999-2000

Figure 29. Graphs showing ninetieth-percentile concentration of volatile organic compounds detected in water samples from urban and mixed-land-use sites in the Great Salt Lake Basins study unit and at sites with similar land uses in study units across the Nation, water years 1999-2000

Figure 30. Boxplots showing dissolved oganic carbon concentration in water samples from fixed sites in the Great Salt Lake Basins study unit. 


\section{TABLES}

Table 1. Drainage area, land use, physiographic province, and ecoregion associated with fixed sites in the Great Salt Lake Basins study unit

Table 2. Streamflow statistics for fixed sites in the Great Salt Lake Basins study unit

Table 3. Number and type of water samples collected and sampling frequency at fixed sites in the Great Salt Lake Basins study unit.

Table 4. Minimum reporting level of physical properties and chemical constituents measured at fixed sites in the Great Salt Lake Basins study unit

Table 5. Nitrogen species analyzed for and calculated from water samples collected at fixed sites in the Great Salt Lake Basins study unit

Table 6. Minimum reporting level of pesticides analyzed for in water samples collected at fixed sites in the Great Salt Lake Basins study unit

Table 7. Pesticides detected in water samples from three fixed sites by using high-performance liquid chromatography/mass spectrometry, Great Salt Lake Basins study unit

Table 8. Summary of pesticides detected in water samples from three fixed sites by using gas chromatography/mass spectrometry, Great Salt Lake Basins study unit

Table 9. Minimum, maximum, and average number of pesticides detected in water samples from three fixed sites, Great Salt Lake Basins study unit

Table 10. Minimum reporting level of volatile organic compounds analyzed for in water samples collected at fixed sites in the Great Salt Lake Basins study unit

Table 11. Summary of volatile organic compound concentrations detected in water samples from two sites in the Great Salt Lake Basins study unit 


\section{CONVERSION FACTORS, DATUMS, ABBREVIATED WATER-QUALITY UNITS, AND ACRONYMS}

\begin{tabular}{rcl}
\hline Multiply & By & \multicolumn{1}{c}{ To obtain } \\
\hline acre-foot (acre-ft) & 1,233 & cubic meter \\
cubic foot per second (ft $\mathrm{ft}^{3}$ ) & 0.02832 & cubic meter per second \\
inch (in.) & 25.4 & millimeter \\
mile (mi) & 1.609 & kilometer \\
square mile ( $\left.\mathrm{mi}^{2}\right)$ & 2.590 & square kilometer \\
\hline
\end{tabular}

Water temperature is reported in degrees Celsius $\left({ }^{\circ} \mathrm{C}\right)$, which can be converted to degrees Fahrenheit $\left({ }^{\circ} \mathrm{F}\right)$ by the following equation:

$$
{ }^{\circ} \mathrm{F}=1.8\left({ }^{\circ} \mathrm{C}\right)+32
$$

Vertical coordinate information is referenced to the North American Vertical Datum of 1988 (NAVD 88); horizontal coordinate information is referenced to the North American Datum of 1983 (NAD 83).

Chemical concentration and water temperature are reported only in metric units. Chemical concentration is reported in milligrams per liter $(\mathrm{mg} / \mathrm{L})$ or micrograms per liter $(\mu \mathrm{g} / \mathrm{L})$. Milligrams per liter is a unit expressing the solute per unit volume (liter) of water. One thousand micrograms per liter is equivalent to 1 milligram per liter. For concentrations less than 7,000 milligrams per liter, the numerical value is about the same as for concentrations in parts per million. Specific conductance is reported in microsiemens per centimeter $(\mu \mathrm{S} / \mathrm{cm})$ at 25 degrees Celsius.

Water year is the 12-month period, October 1 through September 30. The water year is designated by the calendar year in which it ends. Thus, the 12-month period ending September 30, 1999, is water year 1999.

\section{ACRONYMS USED IN THIS REPORT}

\begin{tabular}{ll}
\hline AWQC & Ambient Water-Quality Criteria \\
DO & dissolved oxygen \\
EPA & U.S. Environmental Protection Agency \\
GC/MS & gas chromatography/mass spectrometry \\
GRSL & Great Salt Lake Basins (study unit) \\
HPLC/MS & high-performance liquid chromatography/mass spectrometry \\
LT-MDL & long-term method detection level \\
MRL & minimum reporting level \\
MTBE & methyl tert-butyl ether \\
NAWQA & National Water-Quality Assessment (program) \\
NLCD & National Land Cover Dataset \\
QC & quality control \\
THM & trihalomethane \\
USGS & U.S. Geological Survey \\
VOC & volatile organic compound \\
WY & water year \\
\hline
\end{tabular}


X 


\title{
WATER QUALITY AT FIXED SITES IN THE GREAT SALT LAKE BASINS, UTAH, IDAHO, AND WYOMING, WATER YEARS 1999-2000
}

\author{
By Steven J. Gerner
}

\section{ABSTRACT}

The Great Salt Lake Basins (GRSL) study unit of the National Water-Quality Assessment program encompasses the Bear River, Weber River, and Utah Lake/Jordan River systems, all of which discharge to Great Salt Lake in Utah. Data were collected during each month at 10 sites in the GRSL study unit from October 1998 to September 2000 to define spatial and temporal distribution and variability in concentration of nutrients, major ions, trace elements, suspended sediments, and organic compounds.

Water samples collected from rangeland and forest sites in the GRSL study unit generally contained low concentrations of dissolved solids. Median dissolved-solids concentration in water samples was highest at sites with mixed land uses. Dissolved-solids concentration in some parts of the Bear River during low flow exceeded Utah State standards for agricultural use.

Total-nitrogen concentration in water samples from GRSL sites ranged from 0.06 to 11 milligrams per liter. Water samples from predominantly forest and rangeland sites generally had a low total-nitrogen concentration. Many samples from sites with a higher percentage of agricultural and urban land cover had higher concentrations of total nitrogen. Fifty percent of the samples collected at GRSL sites had total phosphorus concentrations that exceeded 0.1 milligram per liter, the recommended limit for the prevention of nuisance aquatic-plant growth in streams not discharging directly into lakes or impoundments.

Concentration of most trace elements in water samples from the fixed sites generally was low; however, arsenic concentrations, as high as 284 micrograms per liter, sometimes exceeded aquatic-life guidelines. Forty-three pesticides and 35 volatile organic compounds were detected in water samples from three GRSL sites; however, the concentration of most was low, less than 1 microgram per liter. The herbicides atrazine and prometon and the insecticides carbaryl and diazinon were the most frequently detected pesticides. Chloroform and toluene were detected in more than 90 percent of the samples and were the most frequently detected volatile organic compounds. The concentration of carbaryl, diazinon, malathion, and toluene in water samples from GRSL sites sometimes exceeded aquatic-life guidelines.

\section{INTRODUCTION}

The National Water-Quality Assessment (NAWQA) program of the U.S. Geological Survey (USGS) began full-scale implementation in 1991. The objectives of the NAWQA program are to describe the status of and trends in the quality of the Nation's ground-water and surface-water resources as well as to develop an understanding of the natural and human factors that affect those resources (Gilliom and others, 1995). The Great Salt Lake Basins (GRSL) study unit (fig. 1) is 1 of 51 study units that are included in this program. Water-quality investigations began in the first group of 20 study units in 1991. A second group of 16 study units began investigations in 1994, and a third group of 15 study units, including the GRSL, began in 1997.

The fixed-site assessment is a component of the NAWQA surface-water study design used to assess the spatial and temporal distribution of selected constituent groups. Fixed sites are those locations on a stream where water samples are collected at a fixed frequency and a continuous record of streamflow is available. Sites are chosen to represent specific environmental 
settings, such as agricultural land or urban land, or to represent integration of multiple land uses. A site with mixed land uses is most often located at a major node in a drainage system. The fixed-site network established in the GRSL study unit consisted of 10 sites (fig. 1).

\section{Purpose and Scope}

This report describes the GRSL study unit fixedsite network and summarizes water-quality data collected at the fixed sites; which includes measurements of major ions, nutrients, trace elements, suspended sediment, and organic compounds in water samples. Occurrence and distribution of these constituents is compared to land use to evaluate the effect of land use on stream water quality.

Nutrient concentration in water samples from sites was compared with established guidelines to assess whether a site may have a propensity for eutrophication. Trace metal, pesticide, and volatile organic compound (VOC) concentrations in water samples from sites were evaluated by comparing them with established toxicity guidelines for aquatic life.

\section{Description of Study Area}

The GRSL study unit encompasses three major river systems that enter Great Salt Lake: the Bear, the Weber, and the Utah Lake/Jordan River systems (fig. 1). The headwaters of the Bear, the Weber, and the Provo (part of the Utah Lake/Jordan River system) Rivers are in the western end of the Uinta Mountains, located in the southeastern part of the study area. The rivers flow through wide valleys east of the Wasatch Range, then flow through steep-sided canyons that bisect the Wasatch Mountains, and finally discharge into Great Salt Lake. Most of the $14,500 \mathrm{mi}^{2}$ of the GRSL study unit is in Utah, but areas of Idaho and Wyoming are also included. The study unit includes Utah's three largest cities (the Salt Lake City, Ogden, and Provo metropolitan areas) and about 1.9 million people.

A physiographic province is a landform region, an area delineated according to similar terrain that has been shaped by a common geologic history. The GRSL study unit is situated in parts of three major physiographic provinces - the Basin and Range, the Middle Rocky Mountains, and the Colorado Plateau (less than 1 percent) (fig. 2) (Fenneman, 1931). The Basin and Range Physiographic Province makes up most of the low-lying area west of the Wasatch Range and is characterized by isolated, subparallel mountain ranges between adjacent alluvial valleys. The Middle Rocky Mountains Physiographic Province includes the Wasatch and the Uinta Mountains and is characterized by high mountains with associated intermontane valleys.

Ecoregion delineation is based on the premise that relatively homogenous ecological regions can be identified through the analysis of patterns and composition of geology, physiography, vegetation, climate, soils, land use, wildlife, and hydrology (Woods and others, 2001). Five level III ecoregions are present in the GRSL study unit (fig. 3). The Wasatch and Uinta Mountains ecoregion covers 43 percent of the study unit. This region consists of high, glaciated mountains with intervening valleys and foothills, or dissected plateaus. Forestry, livestock grazing, and recreation are the dominant land uses. The Wyoming Basin ecoregion covers 17 percent of the study unit. This ecoregion is a broad intermontane basin dominated by arid grasslands and shrublands and dry or poorly developed soils. It is utilized extensively for grazing and includes some irrigated agriculture. The Central Basin and Range ecoregion covers the western part of the study unit ( 30 percent) and consists of northerly trending fault-block ranges and intervening dry basins. Most of the study unit within this ecoregion consists of valleys and alluvial fans. The bulk of the Central Basin and Range ecoregion is covered by sagebrush steppe vegetation on dry alkaline soils. Urban land use is much more prevalent within the Central Basin and Range than in the other ecoregions represented in the GRSL study unit. The Northern Basin and Range ecoregion covers 7 percent of the study unit. It consists of valleys, rolling hills, alluvial fans, and scattered mountains. Grazing and localized agriculture are the dominant land uses. The final ecoregion, the Middle Rocky Mountains, covers only 3 percent of the study unit in the far northeastern part of the Bear River basin and is primarily shrub and brush rangeland, and forest.

Headwaters of the Bear River, Weber River, and Utah Lake/Jordan River drainage basins originate in quartzite of Precambrian age. At the lower altitudes, below about 5,200 feet, the rivers and Utah Lake are incised into sediments of recent age. The geology of 


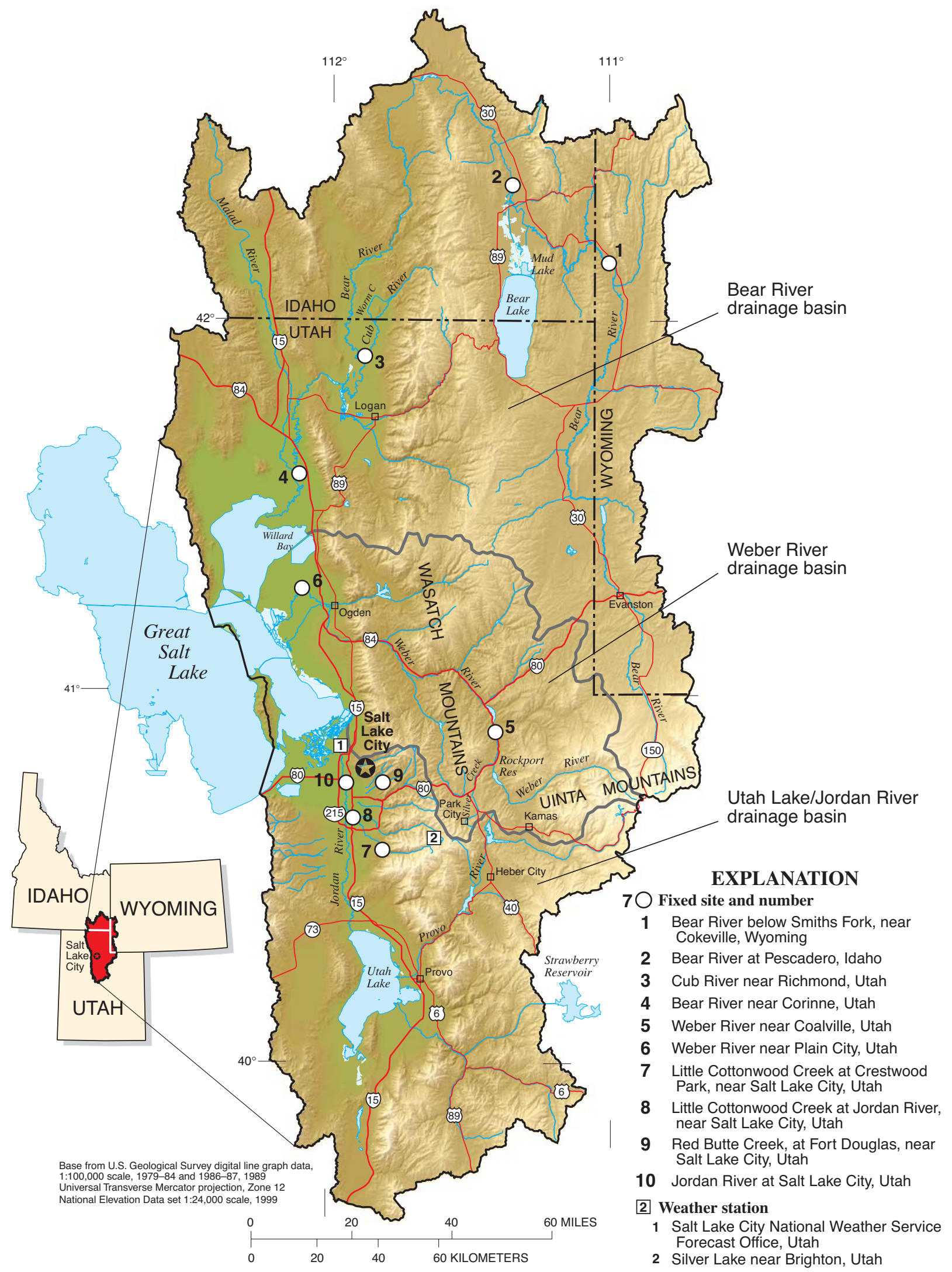

Figure 1. Location of fixed sites in the Great Salt Lake Basins study unit. 


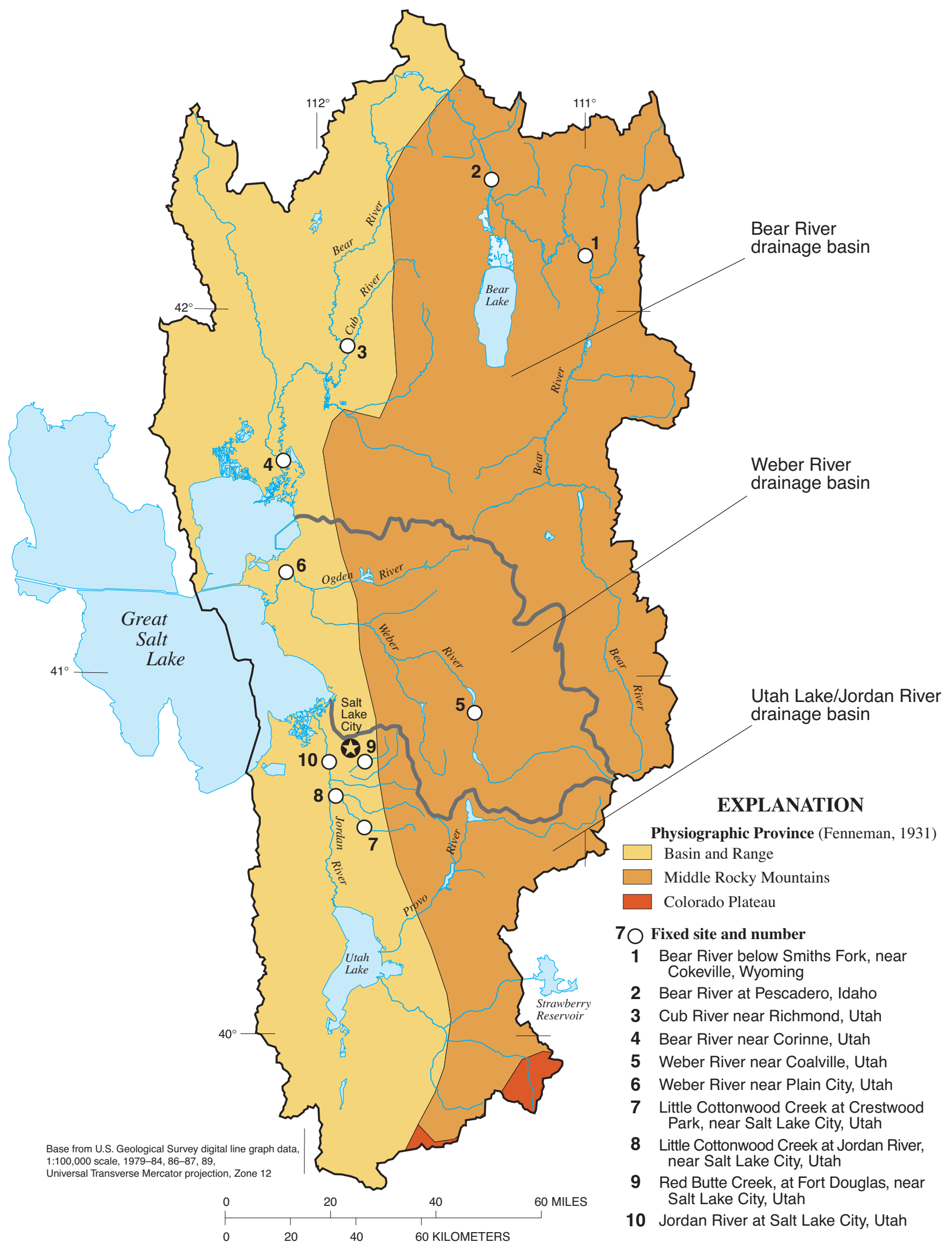

Figure 2. Physiographic provinces of the Great Salt Lake Basins study unit. 


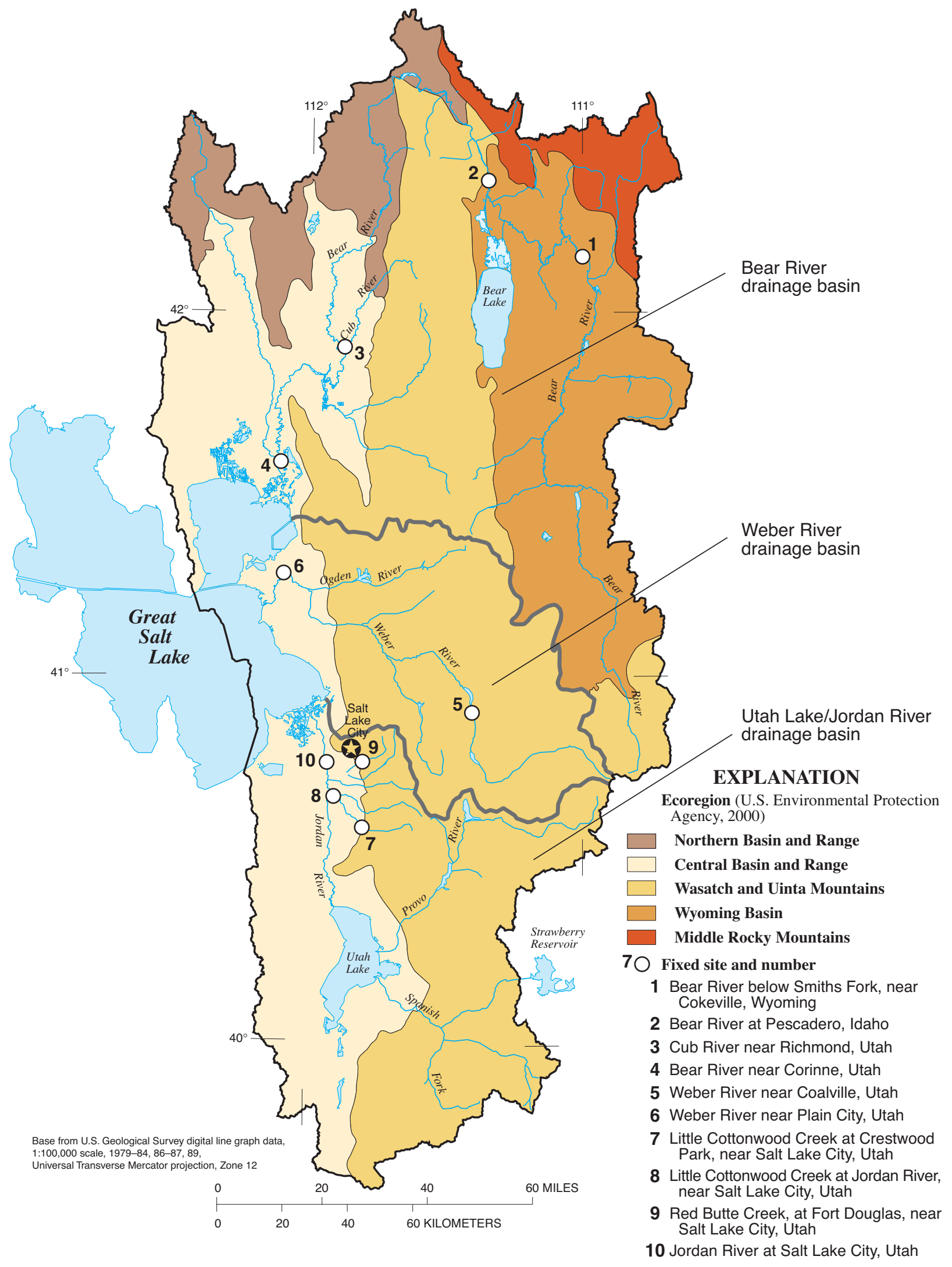

Figure 3. Ecoregions of the Great Salt Lake Basins study unit. Data from Omernik, 1987. 
the intervening area varies somewhat among the three drainage basins.

Older rocks of the Bear River basin are predominantly limestone and dolomite (Dover, 1987); the younger rocks include breccias, conglomerates, and sandstones. Soils in the Bear River basin are derived from the bedrock beneath and surrounding the valleys.

The Weber River basin is made up principally of sedimentary deposits (Utah Department of Natural Resources, 1997b) underlain by older rocks of Precambrian, Paleozoic, and Mesozoic age. The formations of Paleozoic age consist mostly of limestone, dolomite, and shale with different mixtures of quartzite, sandstone, and chert. The rocks of Mesozoic age consist principally of sandstone, siltstone, and shale. Sedimentary deposits in the headwater areas of the Weber River generally consist of silts and clays, gravel, and fine-grained sands.

The western and intermontane valleys of the Utah Lake/Jordan River basin are made up of sediments of Quaternary age. The mountains to the east are made up of rocks of Paleozoic and Precambrian age. The area of the Utah Lake basin that is south of the Uinta Mountains and east of the Wasatch Range is part of the Colorado Plateau Physiographic Province and consists mostly of rocks of Tertiary and Mesozoic age (Baskin and others, 2002).

Knowledge of land use and land cover can enhance our understanding of the natural and anthropogenic factors influencing water quality.
Rangeland and forest are the most common land cover in the GRSL study unit and make up from 65 to 100 percent of total land cover in fixed-site drainage basins (table 1). Agricultural land cover makes up from 0 to 34 percent of total land cover and urban land makes up from less than 1 to 26 percent of total land cover in drainage basins. Land-use/land-cover data were derived from the National Land Cover Dataset (NLCD). This land-cover data set provides a consistent land-cover data layer for the conterminous United States based on 30-meter Landsat thematic mapper data and represents conditions in the early to mid1990s. For this report, the NLCD land-use/land-cover classifications were aggregated to represent the level I classes defined in Anderson and others (1976).

Climate in the Bear, Weber, and Utah Lake/Jordan River basins is typical of mountainous areas in the Western United States. Generally, temperature ranges widely between summer and winter and between day and night. The high mountains have long, cold winters and short, cool summers. The lower valleys are more moderate, with less variance between maximum and minimum temperatures.

Each of the basins in the study unit receives most of its precipitation as snow during the winter months and produces most of its annual runoff during the spring snowmelt periods. Normal annual precipitation ranges from 10 to 16 in. on the valley floors to more than $70 \mathrm{in}$. in the high mountain areas. Precipitation records from weather stations at Salt Lake

Table 1. Drainage area, land use, physiographic province, and ecoregion associated with fixed sites in the Great Salt Lake Basins study unit

$[<$, less than; M, Middle Rocky Mountains; B, Basin and Range; WYB, Wyoming Basin; CBR, Central Basin and Range; WUM, Wasatch and Uinta Mountains]

\begin{tabular}{rlrll}
\hline $\begin{array}{c}\text { Site number } \\
\text { (fig. 1) }\end{array}$ & \multicolumn{1}{c}{ Site name } & $\begin{array}{c}\text { Drainage } \\
\text { area } \\
\text { (square } \\
\text { miles) }\end{array}$ & Site type & Principal land use \\
\hline 1 & Bear River below Smiths Fork, near Cokeville, Wyoming & 2,444 & Indicator & Rangeland \\
2 & Bear River at Pescadero, Idaho & 3,699 & Indicator & Rangeland \\
3 & Cub River near Richmond, Utah & 222 & Indicator & Agriculture \\
4 & Bear River near Corinne, Utah & 7,065 & Integrator & Mixed/agriculture \\
5 & Weber River near Coalville, Utah & 427 & Indicator & Forest/rangeland \\
6 & Weber River near Plain City, Utah & 2,072 & Integrator & Mixed/urban \\
7 & Little Cottonwood Creek at Crestwood Park, at Salt Lake City, Utah & 36 & Indicator & Urban \\
8 & Little Cottonwood Creek at Jordan River, near Salt Lake City, Utah & 45 & Indicator & Urban \\
9 & Red Butte Creek, at Fort Douglas, near Salt Lake City, Utah & 7.21 & Indicator & Forest/rangeland \\
10 & Jordan River at Salt Lake City, Utah & 3,508 & Integrator & Mixed/urban \\
\hline
\end{tabular}
Physiographic Province. 
City National Weather Service Forecast Office, Utah, and Silver Lake near Brighton, Utah, were used to calculate departure of monthly precipitation from the 1971-2000 average monthly precipitation (Desert Research Institute Western Region Climate Center, 2002) (fig. 4). Monthly precipitation during the 1999 water year (WY) generally was less than average during the winter and slightly greater than average during the summer. WY 2000 was very dry in the GRSL study unit, with 8 of 12 months having lessthan-average precipitation.

Combined average annual surface-water runoff from the three river systems in the GRSL was 2.98 million acre-ft during 1931-76 (Waddell and Barton, 1980). Annual surface-water runoff from the GRSL was about 3.1 million acre-ft in WY 1999 and 1.5 million acre-ft in WY 2000. Mean streamflow ranged from $2.36 \mathrm{ft}^{3} / \mathrm{s}$ in Red Butte Creek (WY 2000) to 2,568 $\mathrm{ft}^{3} / \mathrm{s}$ in the Bear River (WY 1999) (table 2). When compared to mean annual streamflow $\left(\mathrm{ft}^{3} / \mathrm{s}\right)$ for the period of record, streamflow at sites in the Bear River drainage basin were 141 to 168 percent of average in WY 1999 and 69 to 122 percent of average in WY 2000. Streams at fixed sites in the Weber and Utah Lake/Jordan River drainage basins were 105 to 125 percent of average for WY 1999 and 47 to 86 percent of average for WY 2000. Annual runoff at all fixed sites during WY 1999 exceeded the average annual runoff for those sites (table 2). The period of record for sites 3,7 , and 8 was insufficient to calculate average

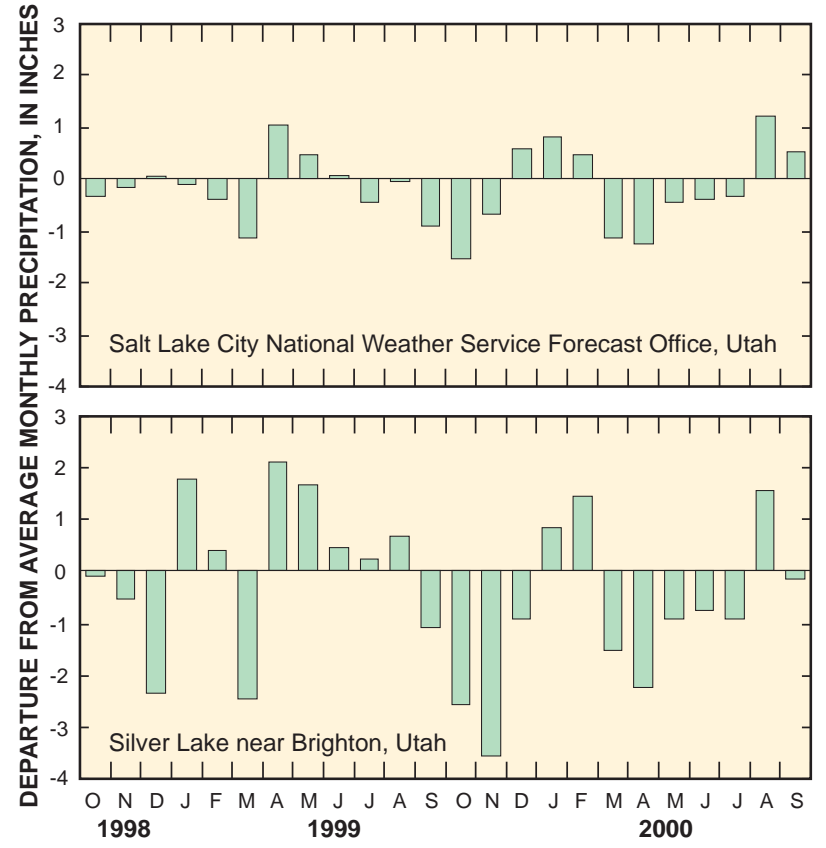

Figure 4. Departure of monthly precipitation from 1971-2000 average at Salt Lake City National Weather Service Forecast Office, Utah, and Silver Lake near Brighton, Utah, weather stations.

annual runoff. Annual runoff during WY 2000 at most fixed sites was less than the average for those sites. Annual runoff at site 2 during WY 2000 was greater than average because of increased flow from reservoir storage for irrigation.

\begin{tabular}{|c|c|c|c|c|c|c|c|c|c|c|}
\hline \multirow{2}{*}{$\begin{array}{l}\text { Site number } \\
\text { (fig. 1) }\end{array}$} & \multicolumn{8}{|c|}{$\begin{array}{l}\text { Land use/land cover } \\
\text { (percent) }\end{array}$} & \multirow{2}{*}{$\begin{array}{l}\text { Physio- } \\
\text { graphic } \\
\text { province }\end{array}$} & \multirow{2}{*}{$\begin{array}{l}\text { Dominant } \\
\text { ecoregion }\end{array}$} \\
\hline & Rangeland & Forest & $\begin{array}{l}\text { Agri- } \\
\text { culture }\end{array}$ & Urban & Wetland & Water & $\begin{array}{l}\text { Snow/ } \\
\text { ice }\end{array}$ & Barren & & \\
\hline 1 & 75 & 15 & 7 & $<1$ & 2 & $<1$ & $<1$ & $<1$ & $\bar{M}$ & WYB \\
\hline 2 & 70 & 15 & 8 & $<1$ & 3 & 4 & $<1$ & $<1$ & M & WYB \\
\hline 3 & 43 & 22 & 34 & $<1$ & $<1$ & $<1$ & $<1$ & $<1$ & B & CBR \\
\hline 4 & 61 & 16 & 18 & $<1$ & 2 & 2 & $<1$ & $<1$ & B & CBR \\
\hline 5 & 32 & 61 & 5 & $<1$ & $<1$ & $<1$ & $<1$ & $<1$ & M & WUM \\
\hline 6 & 57 & 35 & 5 & 2 & $<1$ & $<1$ & $<1$ & $<1$ & B & WUM \\
\hline 7 & 35 & 46 & 1 & 10 & $<1$ & $<1$ & $<1$ & 7 & $\mathrm{M} / \mathrm{B}^{1}$ & CBR \\
\hline 8 & 29 & 37 & 2 & 26 & $<1$ & $<1$ & $<1$ & 6 & B & CBR \\
\hline 9 & 56 & 44 & 0 & $<1$ & 0 & $<1$ & 0 & 0 & $\mathrm{M} / \mathrm{B}^{1}$ & WUM \\
\hline 10 & 40 & 42 & 7 & 5 & $<1$ & 4 & $<1$ & 1 & B & CBR \\
\hline
\end{tabular}




\section{Data Collection and Analysis}

Water samples were collected monthly at the sites and analyzed for major ions, nutrients, suspended sediment, and organic carbon (table 3). Additionally, multiple samples from sites $5,7,8$, and 10 were analyzed for trace elements. Water samples were collected weekly to biweekly at sites 3, 8, and 10 during March to August 1999 and were analyzed for the constituents mentioned above plus pesticides and VOCs (VOCs at sites 8 and 10 only). Additional samples were collected at some sites during periods of extreme flow. Streamflow and temperature were continuously monitored at all sites. Specific conductance was continuously monitored at sites 3,7 , 8,9 , and 10 .

Water samples were collected at each of the 10 sites by using field procedures outlined in Shelton $(1994,1997)$ and were processed in the field immediately after collection to reduce the possibility of chemical or biological alteration. Samples were analyzed at the USGS National Water Quality Laboratory in Denver, Colorado.

Table 2. Streamflow statistics for fixed sites in the Great Salt Lake Basins study unit

[WY, water year; $\mathrm{ft}^{3} / \mathrm{s}$, cubic feet per second; Highest annual mean: Year of record flow in parentheses; Lowest annual mean: Year of record flow in parentheses; na, not available]

\begin{tabular}{|c|c|c|c|c|c|c|}
\hline \multirow{2}{*}{$\begin{array}{c}\text { Site } \\
\text { number } \\
\text { (fig. 1) }\end{array}$} & \multirow[b]{2}{*}{ Site name } & \multirow{2}{*}{$\begin{array}{l}\text { USGS identification } \\
\text { number }\end{array}$} & \multirow{2}{*}{$\begin{array}{l}\text { Period of } \\
\text { streamflow record }\end{array}$} & \multicolumn{3}{|c|}{$\begin{array}{c}\text { Runoff } \\
\text { (acre-feet) }\end{array}$} \\
\hline & & & & WY 1999 & WY 2000 & $\begin{array}{c}\text { Mean annual } \\
\text { (period of } \\
\text { record) }\end{array}$ \\
\hline 1 & $\begin{array}{l}\text { Bear River below Smiths Fork, near Cokeville, } \\
\text { Wyoming }\end{array}$ & 10038000 & $1955-2000$ & 497,100 & 199,200 & 327,600 \\
\hline 2 & Bear River at Pescadero, Idaho & 10068500 & $1923-2000$ & 769,800 & 561,300 & 459,000 \\
\hline 3 & Cub River near Richmond, Utah & 10102200 & $1963,1999-2000$ & 130,800 & 55,440 & na \\
\hline 4 & Bear River near Corinne, Utah & 10126000 & $1950-2000$ & $1,859,000$ & 904,400 & $1,315,000$ \\
\hline 5 & Weber River near Coalville, Utah & 10130500 & $1958-2000$ & 191,800 & 120,300 & 160,600 \\
\hline 6 & Weber River near Plain City, Utah & 10141000 & $1949-2000$ & 448,600 & 171,700 & 366,500 \\
\hline 7 & $\begin{array}{l}\text { Little Cottonwood Creek at Crestwood Park, at Salt } \\
\text { Lake City, Utah }\end{array}$ & 10167800 & $1999-2000$ & 12,479 & 10,639 & na \\
\hline 8 & $\begin{array}{l}\text { Little Cottonwood Creek at Jordan River, near Salt } \\
\text { Lake City, Utah }\end{array}$ & 10168000 & $\begin{array}{l}1980-81,1999- \\
2000\end{array}$ & 16,501 & 15,313 & na \\
\hline 9 & $\begin{array}{l}\text { Red Butte Creek, at Fort Douglas, near Salt Lake City, } \\
\text { Utah }\end{array}$ & 10172200 & $1964-2000$ & 3,960 & 1,710 & 3,160 \\
\hline 10 & Jordan River at Salt Lake City, Utah & 10171000 & 1944-2000 & 109,000 & 90,180 & 104,300 \\
\hline
\end{tabular}

\begin{tabular}{|c|c|c|c|c|c|c|c|c|c|c|}
\hline \multirow{3}{*}{$\begin{array}{l}\text { Site number } \\
\text { (fig. 1) }\end{array}$} & \multirow{3}{*}{$\begin{array}{c}\text { USGS identification } \\
\text { number }\end{array}$} & \multicolumn{9}{|c|}{ Streamflow $\left(\mathrm{ft}^{3} / \mathrm{s}\right)$} \\
\hline & & \multicolumn{2}{|c|}{ Annual mean } & \multirow{2}{*}{$\begin{array}{l}\text { Mean annual } \\
\text { (period of } \\
\text { record) }\end{array}$} & \multirow{2}{*}{\multicolumn{2}{|c|}{ Highest annual mean }} & \multirow{2}{*}{\multicolumn{2}{|c|}{ Lowest annual mean }} & \multirow{2}{*}{ Highest daily } & \multirow{2}{*}{ Lowest daily } \\
\hline & & WY 1999 & WY 2000 & & & & & & & \\
\hline 1 & 10038000 & 687 & 274 & 452 & 1,049 & (1984) & 112 & (1977) & 5,400 & 31.0 \\
\hline 2 & 10068500 & 1,063 & 773 & 634 & 1,733 & (1984) & 266 & (1945) & 4,280 & 23.0 \\
\hline 3 & 10102200 & 181 & 76.4 & na & 181 & (1999) & 76.4 & (2000) & 949 & 5.0 \\
\hline 4 & 10126000 & 2,568 & 1,246 & 1,815 & 5,050 & (1984) & 435 & (1992) & 14,300 & 47.0 \\
\hline 5 & 10130500 & 265 & 166 & 222 & 485 & (1986) & 71.1 & (1961) & 1,860 & 7.0 \\
\hline 6 & 10141000 & 620 & 237 & 506 & 1,427 & (1986) & 65.3 & (1988) & 9,970 & 1.0 \\
\hline 7 & 10167800 & 34.2 & 14.6 & na & 34.2 & (1999) & 14.7 & (2000) & 359 & 1.3 \\
\hline 8 & 10168000 & 45.2 & 21.0 & na & 45.2 & (1999) & 21.1 & (2000) & 357 & 1.3 \\
\hline 9 & 10172200 & 5.47 & 2.36 & 4.37 & 12.5 & (1983) & 1.12 & (1990) & 95 & .38 \\
\hline 10 & 10171000 & 151 & 124 & 144 & 223 & (1985) & 92.3 & (1964) & 337 & .00 \\
\hline
\end{tabular}


Table 3. Number and type of water samples collected and sampling frequency at fixed sites in the Great Salt Lake Basins study unit

[GC/MS, gas chromatography/mass spectrometry; HPLC/MS, high-performance liquid chromatography/mass spectrometry]

\begin{tabular}{|c|c|c|c|c|c|c|c|c|c|c|c|}
\hline \multirow{3}{*}{$\begin{array}{c}\text { Site } \\
\text { number }\end{array}$} & \multicolumn{8}{|c|}{ Number and type of sample } & \multicolumn{3}{|c|}{ Sample frequency } \\
\hline & \multirow[b]{2}{*}{ Major ions } & \multirow[b]{2}{*}{ Nutrients } & \multirow{2}{*}{$\begin{array}{l}\text { Trace } \\
\text { elements }\end{array}$} & \multirow{2}{*}{$\begin{array}{l}\text { Suspended } \\
\text { sediment }\end{array}$} & \multirow{2}{*}{$\begin{array}{l}\text { Organic } \\
\text { carbon }\end{array}$} & \multicolumn{2}{|c|}{ Pesticides } & \multirow{2}{*}{$\begin{array}{c}\text { Volatile } \\
\text { organic } \\
\text { compounds }\end{array}$} & \multirow{2}{*}{$\begin{array}{l}\text { Monthly } \\
\text { sampling } \\
\text { period }\end{array}$} & \multirow{2}{*}{$\begin{array}{c}\text { Weekly or } \\
\text { biweekly } \\
\text { sampling } \\
\text { period }\end{array}$} & \multirow{2}{*}{$\begin{array}{l}\text { Extreme-flow } \\
\text { sample }\end{array}$} \\
\hline & & & & & & GC/MS & HPLC/MS & & & & \\
\hline 1 & 24 & 24 & 1 & 24 & 24 & 0 & 0 & 0 & $10 / 98-9 / 00$ & None & No \\
\hline 2 & 24 & 24 & 1 & 23 & 23 & 0 & 0 & 0 & $10 / 98-9 / 00$ & None & No \\
\hline 3 & 32 & 32 & 1 & 29 & 32 & 26 & 16 & 0 & $10 / 98-9 / 00$ & $4 / 99-9 / 99$ & Yes \\
\hline 4 & 25 & 25 & 2 & 24 & 25 & 0 & 0 & 0 & $10 / 98-9 / 00$ & None & Yes \\
\hline 5 & 24 & 24 & 20 & 23 & 24 & 1 & 0 & 0 & $10 / 98-9 / 00$ & None & No \\
\hline 6 & 26 & 26 & 1 & 26 & 26 & 0 & 0 & 0 & $10 / 98-9 / 00$ & None & Yes \\
\hline 7 & 29 & 29 & 25 & 26 & 29 & 9 & 4 & 2 & $10 / 98-9 / 00$ & None & Yes \\
\hline 8 & 45 & 45 & 49 & 44 & 43 & 42 & 24 & 32 & $10 / 98-9 / 00$ & 3/99-9/99 & Yes \\
\hline 9 & 27 & 27 & 2 & 27 & 26 & 1 & 1 & 1 & $10 / 98-9 / 00$ & None & Yes \\
\hline 10 & 36 & 35 & 36 & 37 & 35 & 32 & 22 & 26 & $10 / 98-9 / 00$ & 3/99-9/99 & Yes \\
\hline
\end{tabular}

Data collected during this study are available in the USGS National Water Information System database and the USGS NAWQA Data Warehouse. These databases are subject to periodic review and possible revision. Major ion, nutrient, trace metal, dissolved and suspended organic carbon, and sediment data also are available in USGS Water-Data Reports (Herbert and others, 2000, 2001, and 2002).

In this report, the term "dissolved" refers to solutes detected in a water sample after it has passed through a 0.45 -micron filter or a 0.70 -micron filter (pesticide samples only). Dissolved-solids concentrations in this report refer to measurements derived from analysis of sample residue on evaporation at $180^{\circ} \mathrm{C}$.

A minimum reporting level (MRL) is the smallest measured concentration of a constituent that may be reliably reported when using a given analytical method. Concentrations are reported as less than the MRL for samples in which the constituent either was not detected or was detected at a concentration less than the MRL. Constituents that were detected at concentrations between the long-term method detection level (LT-MDL) and MRL were estimated. The LT-MDL controls false positive error, and the chance of falsely reporting a concentration at or greater than the LT-MDL for a sample that did not contain the analyte is predicted to be less than or equal to 1 percent. Estimated concentrations are noted with a remark code of "e." These data should be used with the understanding that their uncertainty is greater than that of data reported without the "e" remark code.

Concentrations with the "e" remark code were considered as detections in the data analysis and were included in statistical analysis.

The MRL of a constituent can be the largest influence on the detection frequency of that constituent. A common reporting limit of $0.05 \mu \mathrm{g} / \mathrm{L}$ is sometimes used in the report to compare the detection frequencies of pesticides that have different MRLs. Censoring detections less than $0.05 \mu \mathrm{g} / \mathrm{L}$ resulted in a slight loss of detection information; however, with a common reporting limit, a more uniform comparison of detection frequencies is possible. The same method was applied to VOC data by using a common reporting limit of $0.2 \mu \mathrm{g} / \mathrm{L}$.

Quality-control (QC) samples were collected at the GRSL sites following NAWQA protocols (Shelton, 1994; Mueller and others, 1997). These samples consisted of field blanks, equipment blanks, replicates, and field matrix spikes. On the basis of QC results, it was concluded that measurements of concentration in the environmental samples were of sufficiently high quality that presence or absence of most constituents, concentration distributions, and comparisons to waterquality criteria could be determined. Concentrations of total and dissolved ammonia plus organic nitrogen and orthophosphate may have a positive bias because of contamination from equipment or field procedures. Concentrations of aluminum and zinc, near the MRL, probably have a positive bias because of contamination. A detailed discussion of QC samples and results from GRSL study-unit sites is available in Gerner (2003). 


\section{Water-Quality Issues}

A liaison committee of Federal, State, and local agencies, universities associated with water management and water quality, and interested citizen groups was formed in 1994 to discuss the major waterquality issues relative to the GRSL study unit. Several water-quality issues related to surface water were identified by this group including nutrient releases into streams from nonpoint sources, increased sediment transport as a result of urbanization and streamflow fluctuations downstream from dams, transport of contaminants associated with suspended sediment, and leachate from mine tailings and metal refineries.

A State listing of impaired water bodies is required by Section 303(d) of the Clean Water Act. Section 305(b) of the Clean Water Act requires States to assess their water quality biennially and report those findings to the U.S. Environmental Protection Agency (EPA). A review of the 2002 303(d) listing of impaired water bodies and 305(b) assessment of beneficial-use support provided by the Utah Department of Environmental Quality for the State of Utah provides further insight into some of the water-quality issues affecting streams in the GRSL study unit. Areas of concern identified in these reports include (1) nutrients, dissolved oxygen, hydrologic modification, and sediment in the Bear River drainage basin; (2) nutrients, dissolved oxygen, and sediment in the Weber River drainage basin; and (3) metals, dissolved-solids concentration, sediment, fecal coliform, and flow and riparian alteration in the Utah Lake/Jordan River drainage basin (Utah Department of Environmental Quality, 2002a, 2002b).

\section{Description of Fixed-Site Network}

The fixed sites in the GRSL study unit (fig. 1) are stream-sampling sites that were established for monitoring stream quality during a 2-year period. Sites were categorized as either indicator or integrator sites (table 1). Indicator sites are located near the mouth of drainage basins that are relatively homogenous with a dominant land use and physiographic condition. Stream samples from indicator sites provide documentation of water-quality conditions relative to that dominant land use (Gilliom and others, 1995). Seven indicator sites were selected for the GRSL study unit: Bear River below Smiths Fork, Bear River at
Pescadero, Cub River near Richmond, Weber River near Coalville, Little Cottonwood Creek at Crestwood Park, Little Cottonwood Creek at Jordan River, and Red Butte Creek at Fort Douglas. Integrator sites are located near the mouth of large rivers in drainage basins with complex mixes of land use/land cover and multiple natural and human-related factors that affect water quality. These sites are on streams with large drainage basins that include a substantial part of the study unit. Because of the complex mix of land uses affecting water quality at these sites, they are further categorized and referred to as mixed-land-use sites in this report. Three integrator (mixed-land-use) sites were selected for the GRSL study unit: Bear River near Corinne, Weber River at Plain City, and Jordan River at Salt Lake City. About 95 percent of the drainage area of the study unit contributes runoff to the three mixedland-use sites. Sites are referred to throughout this report by either site name or number (fig. 1, table 1).

\section{Bear River Drainage Basin}

The Bear River is the longest river in North America that does not drain into an ocean. The Bear River meanders through Utah, Wyoming, and Idaho before it enters Utah again where it ends in Great Salt Lake (fig. 1). Near Montpelier, Idaho, the Bear River is usually diverted into the Mud Lake/Bear Lake reservoir system. About 140,000 years ago, lava flows from near Soda Springs, Idaho, blocked the Bear River channel and diverted the river from the Snake River Plain into the Great Basin. After isolation from each other for thousands of years, a Bear Lake/Bear River connection was reestablished in 1911-12 to use the lake as a waterstorage reservoir. The Rainbow canal diverts water from the Bear River into Mud Lake. This water can then either be diverted into Bear Lake or returned to the Bear River. Water from Bear Lake can later be pumped through the Lifton pumping station to the outlet canal and back to the Bear River. Enrichment of Bear Lake with nutrients and sediment from the Bear River has been an ongoing concern of water managers and users in the Bear River drainage basin.

About 62 percent of the total average annual runoff of surface water (1931-76) to Great Salt Lake is from the Bear River. Above Bear Lake most of this basin is composed of forest and rangeland, whereas agricultural and urban land cover predominate downstream from Bear Lake. A network of dams, reservoirs, and diversion structures regulates flow in 
the Bear River for irrigation and hydroelectric power production, and modifies the natural hydrologic variability of the stream and the physical, chemical, and biological conditions of the stream. Flow modification from dams and reservoirs affects streambank stability and sediment concentration. Bear Lake has a usable storage capacity of 1,421,000 acre-ft and is the largest reservoir on the Bear River system.

During 1995, irrigation for agriculture accounted for an estimated 92 percent of all water use, and public supply accounted for an estimated 4 percent of all water use in the Bear River drainage (Baskin and others, 2002). Nutrient and sediment loading related to agricultural land cover are the primary water-quality issues on the Bear River. Channelization, streamflow modification, and grazing of rangelands contribute to sediment loads in the upper part of the drainage basin. Feedlots, dairy operations, and irrigated crops contribute to nutrient loads in the lower drainage basin. Most tributaries to the Bear River are seasonally diverted for irrigation. Irrigation return flow, with generally high dissolved-solids concentration, affects the water quality of the Bear River.

\section{Bear River below Smiths Fork}

Site 1, the Bear River below Smiths Fork, is 61 mi above Mud Lake and just upstream from the Wyoming/Idaho state line. The drainage basin above site 1 is 2,444 $\mathrm{mi}^{2}$ in area and lies within the Wyoming Basin and Wasatch and Uinta Mountains ecoregions. This site was selected because it provided a reference for effects of rangeland use on water quality and is an indicator of water quality in the Bear River above Bear Lake.

Land cover in the drainage basin is primarily rangeland (75 percent) and forest (15 percent) (table 1$)$. Daily streamflow ranged from $102 \mathrm{ft}^{3} / \mathrm{s}$ to $2,860 \mathrm{ft}^{3} / \mathrm{s}$ (fig. 5). Twenty-four water samples were collected at this site for chemical analysis, and corresponding streamflow ranged from $108 \mathrm{ft}^{3} / \mathrm{s}$ to $2,160 \mathrm{ft}^{3} / \mathrm{s}$.

\section{Bear River at Pescadero}

Site 2, the Bear River at Pescadero, is $19 \mathrm{mi}$ downstream from Bear Lake and was selected as a sampling site because of its historical streamflow and water-quality record and proximity to the outflow from the Mud Lake/Bear Lake reservoir system. Comparison of water chemistry upstream from Bear Lake at site 1 with water chemistry at site 2 provides insight into the changes that occur as the Bear River travels through Mud Lake or receives inflow from water pumped out of Bear Lake.

The drainage basin above site 2 is $3,699 \mathrm{mi}^{2}$ in area and is primarily in the Wyoming Basin ecoregion. Land cover in the drainage basin is mainly rangeland (70 percent) and forest (15 percent). Streamflow was greatly influenced by managed releases from Bear Lake. Daily mean streamflow ranged from 94 to 1,760 $\mathrm{ft}^{3} / \mathrm{s}$ (fig. 6). Twenty-four water samples were collected at site 2 for chemical analysis, and corresponding streamflow ranged from 180 to $1,650 \mathrm{ft}^{3} / \mathrm{s}$.

\section{Cub River near Richmond}

Site 3, Cub River near Richmond, is near the mouth of the Cub River drainage basin, $3.9 \mathrm{mi}$ upstream from the confluence with the Bear River. The drainage basin above site 3 is $222 \mathrm{mi}^{2}$ in area and lies within the Central Basin and Range and Wasatch and Uinta Mountains ecoregions. Land cover in the basin is mainly rangeland (43 percent), agriculture (34 percent), and forest (22 percent).

This site was selected to determine the effects of agriculture on water quality in the GRSL study unit. The percentage of agricultural land cover in this basin is high relative to that of most basins in the GRSL study unit (table 1). During the summer, most of the flow from the upper Cub River drainage basin is withdrawn for irrigation, and streamflow at this site consists mainly of irrigation return, treated waste water, and ground-water inflow. Snowmelt is the largest component of streamflow from March through June. Daily mean streamflow ranged from 5.6 to $949 \mathrm{ft}^{3} / \mathrm{s}$ (fig. 7). Thirty-three water samples were collected at this site for chemical analysis, and corresponding streamflow ranged from 15 to $960 \mathrm{ft}^{3} / \mathrm{s}$. 


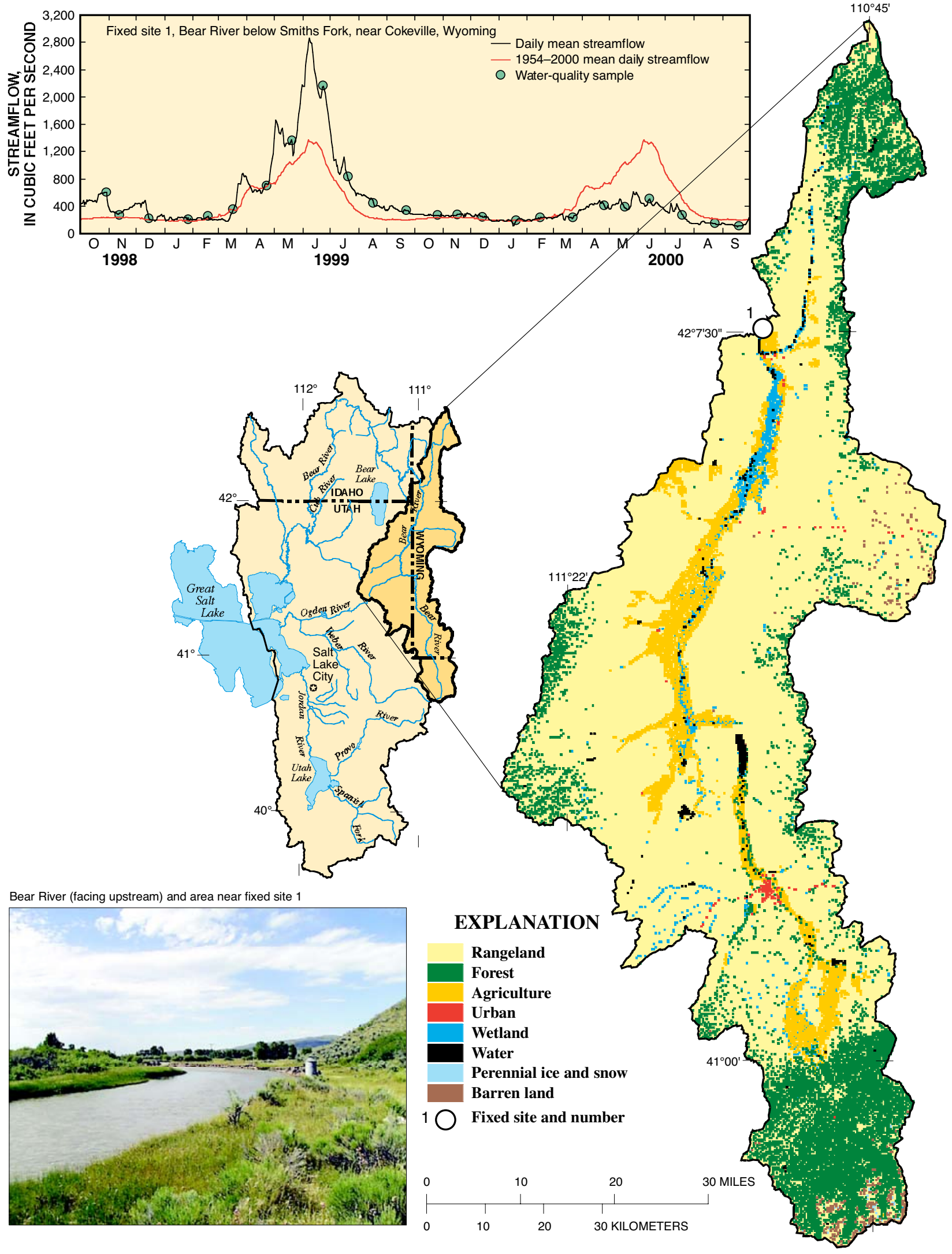

Figure 5. Land use/land cover, drainage basin location, and streamflow for the Bear River below Smiths Fork, near Cokeville, Wyoming 


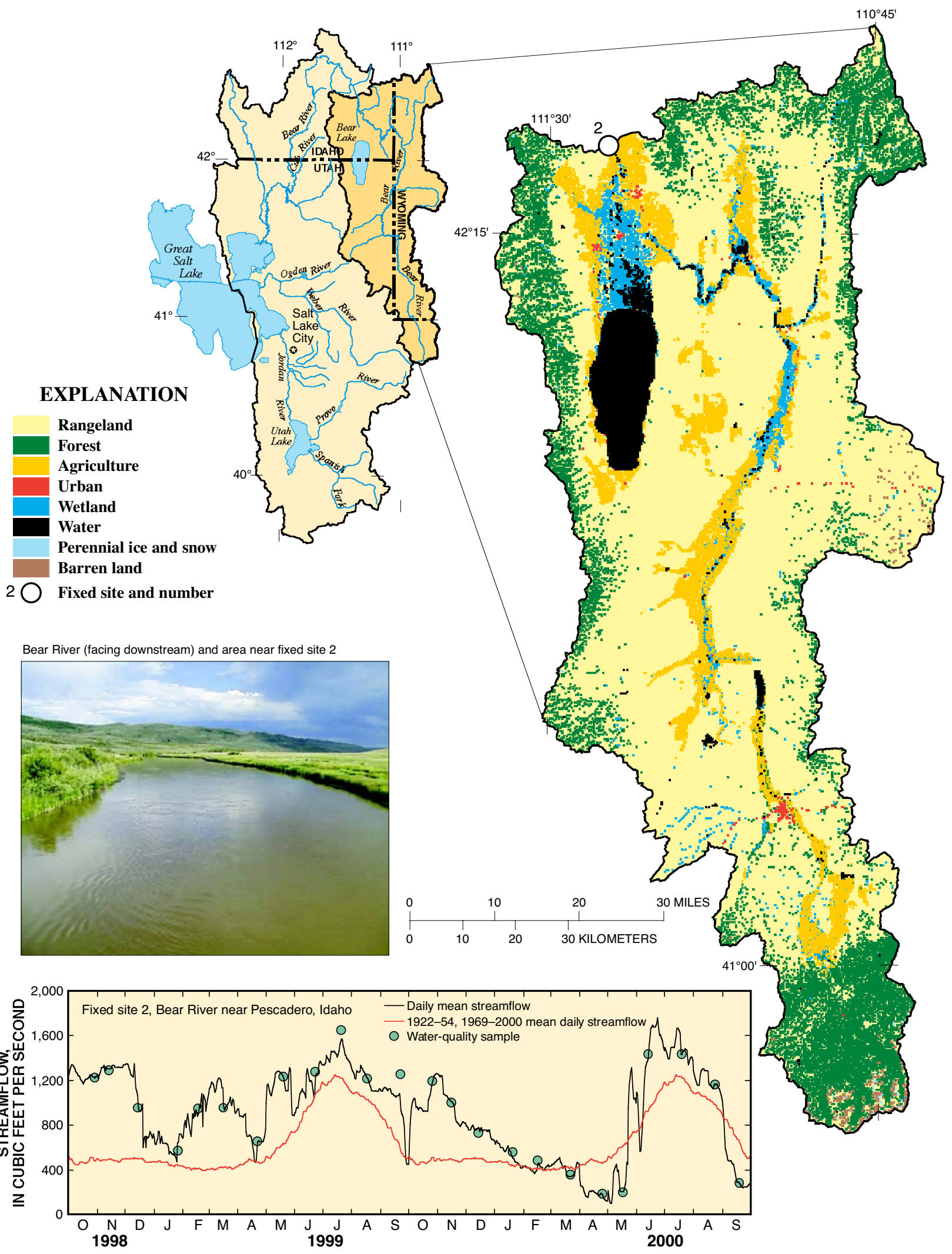

Figure 6. Land use/land cover, drainage basin location, and streamflow for the Bear River at Pescadero, Idaho. 

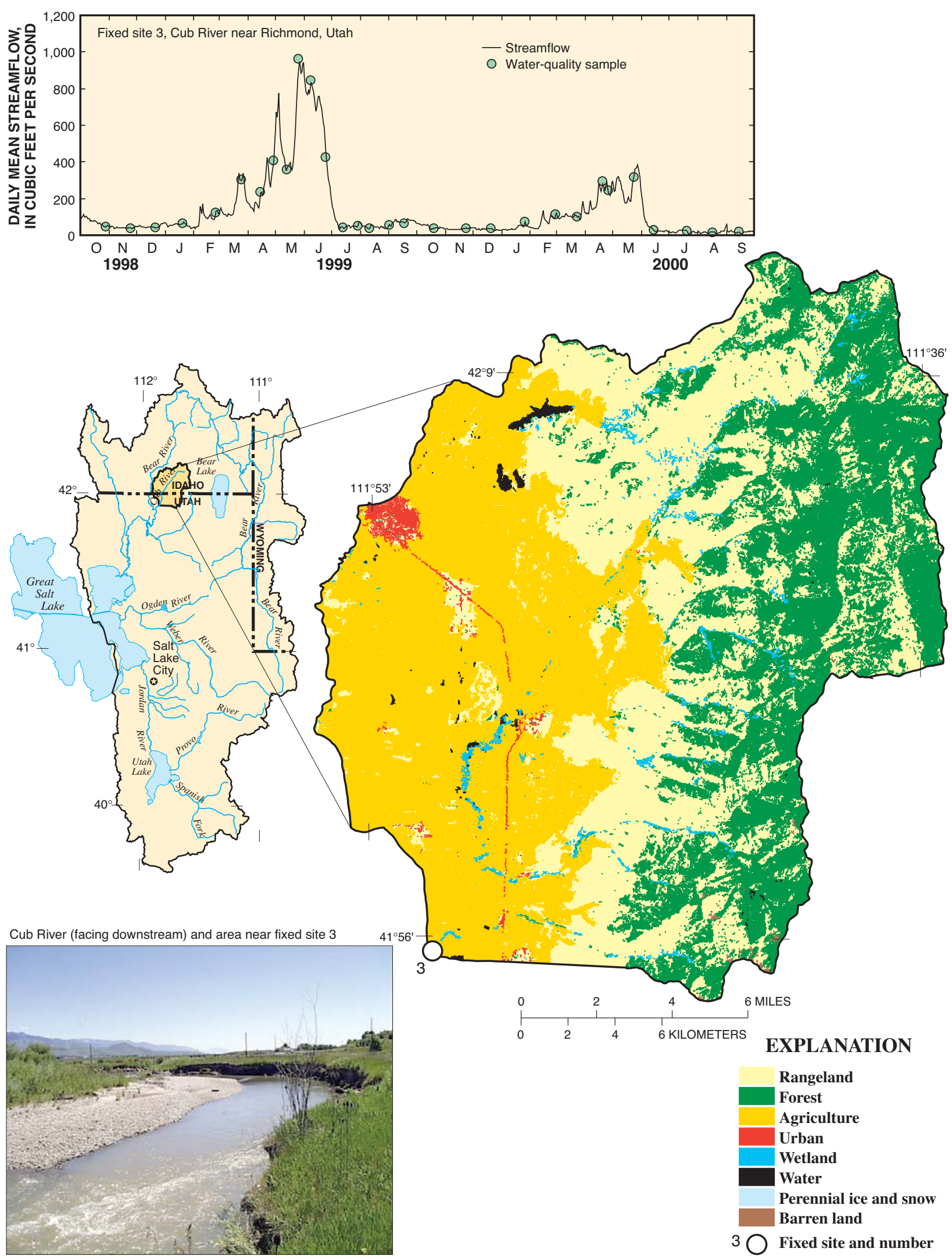

Figure 7. Land use/land cover, drainage basin location, and streamflow for the Cub River near Richmond, Utah. 


\section{Bear River near Corinne}

Site 4, the Bear River near Corinne, is near the mouth of the Bear River, $21 \mathrm{mi}$ above Great Salt Lake. The drainage basin above site 4 is about $7,065 \mathrm{mi}^{2}$ in area. Site 4 lies within the Central Basin and Range ecoregion. Land cover in the area above this site is mainly rangeland (61 percent), forest (16 percent), and agriculture (18 percent) (table 1). Agriculture is probably the dominant land use influencing water quality at this site.

The natural flow of the river is affected by upstream reservoirs, power development, diversions for irrigation, and return flow from irrigated areas. Daily mean streamflow ranged from 74 to $6,020 \mathrm{ft}^{3} / \mathrm{s}$ (fig. 8). Twenty-five water samples were collected at this site for chemical analysis, and corresponding streamflow ranged from 92 to $5,380 \mathrm{ft}^{3} / \mathrm{s}$.

\section{Weber River Drainage Basin}

About 23 percent of the total average annual runoff of surface water (1931-76) to Great Salt Lake is from the Weber River. The Weber River drainage basin is primarily forest and rangeland in the upper drainage basin with increasing agricultural and urban land uses toward the mouth of the Weber River at Great Salt Lake. Intensive urban development is occurring in parts of the upper drainage basin, including the areas surrounding Park City, Heber City, and Kamas, and in the lower drainage basin in the Ogden area near the mouth of the Weber River. The basin is affected by historical mining activities that occurred in some upper drainage-basin areas.

Much of the water in the main stem of the Weber River is diverted for irrigation during the summer months, although minimum streamflows are maintained below most reservoirs on the Weber and Ogden Rivers (Utah Department of Natural Resources, 1997b). During 1995, irrigation for agriculture accounted for an estimated 82 percent of all water use, and public supply accounted for an estimated 16 percent of all water use in the Weber River drainage basin (Baskin and others, 2002). Residential and commercial developments are replacing farms and ranches in many parts of the basin, resulting in more municipal and industrial use of water and less agricultural use. Eight major reservoirs provide storage and redistribution of water in the Weber River drainage basin, as well as providing for flood control and recreational opportunities.

\section{Weber River near Coalville}

Site 5, the Weber River near Coalville, is $9 \mathrm{mi}$ downstream from Rockport Reservoir. Streamflow at this site is highly regulated with many diversions for irrigation upstream from the site. The drainage basin above site 5 is $427 \mathrm{mi}^{2}$ in area and lies within the Wasatch and Uinta Mountains ecoregion. Land use in the drainage basin includes forest (61 percent), rangeland (32 percent), and agriculture (5 percent). This site was selected as an indicator of the effects of rangeland and agricultural land use on stream chemistry in the GRSL study unit. This site is about 5.6 mi downstream from the confluence with Silver Creek, a tributary affected by historical mining practices in the Park City area and a source of metal-enriched sediment for the Weber River (Giddings and others, 2001).

Daily mean streamflow ranged from 43 to 1,310 $\mathrm{ft}^{3} / \mathrm{s}$ (fig. 9). Twenty-four water samples were collected at this site, and corresponding streamflow ranged from 48 to $421 \mathrm{ft}^{3} / \mathrm{s}$.

\section{Weber River near Plain City}

Site 6, Weber River near Plain City, is near the mouth of the drainage basin, $13 \mathrm{mi}$ upstream of where the river empties into Great Salt Lake. The drainage basin above site 6 is 2,072 $\mathrm{mi}^{2}$ in area and lies within the Central Basin and Range and Wasatch and Uinta Mountains ecoregions. Land cover in the drainage is mainly rangeland (57 percent), and forest (35 percent). The amount of urban land cover in this basin is only about 2 percent (table 1). This site is immediately downstream from the waste-water treatment plant for the Ogden metropolitan area, an urban area that has a substantial effect on water quality.

During the irrigation season (generally May through September), most of the flow from the upper Weber River drainage basin was diverted for irrigation and public supply, and streamflow at this site consisted mainly of irrigation return, urban runoff, waste-water effluent, and ground-water inflow. Daily mean streamflow ranged from 51 to $3,220 \mathrm{ft}^{3} / \mathrm{s}$ (fig. 10). Twenty-six water samples were collected at this site, and the corresponding streamflow ranged from 58 to $3,130 \mathrm{ft}^{3} / \mathrm{s}$. 


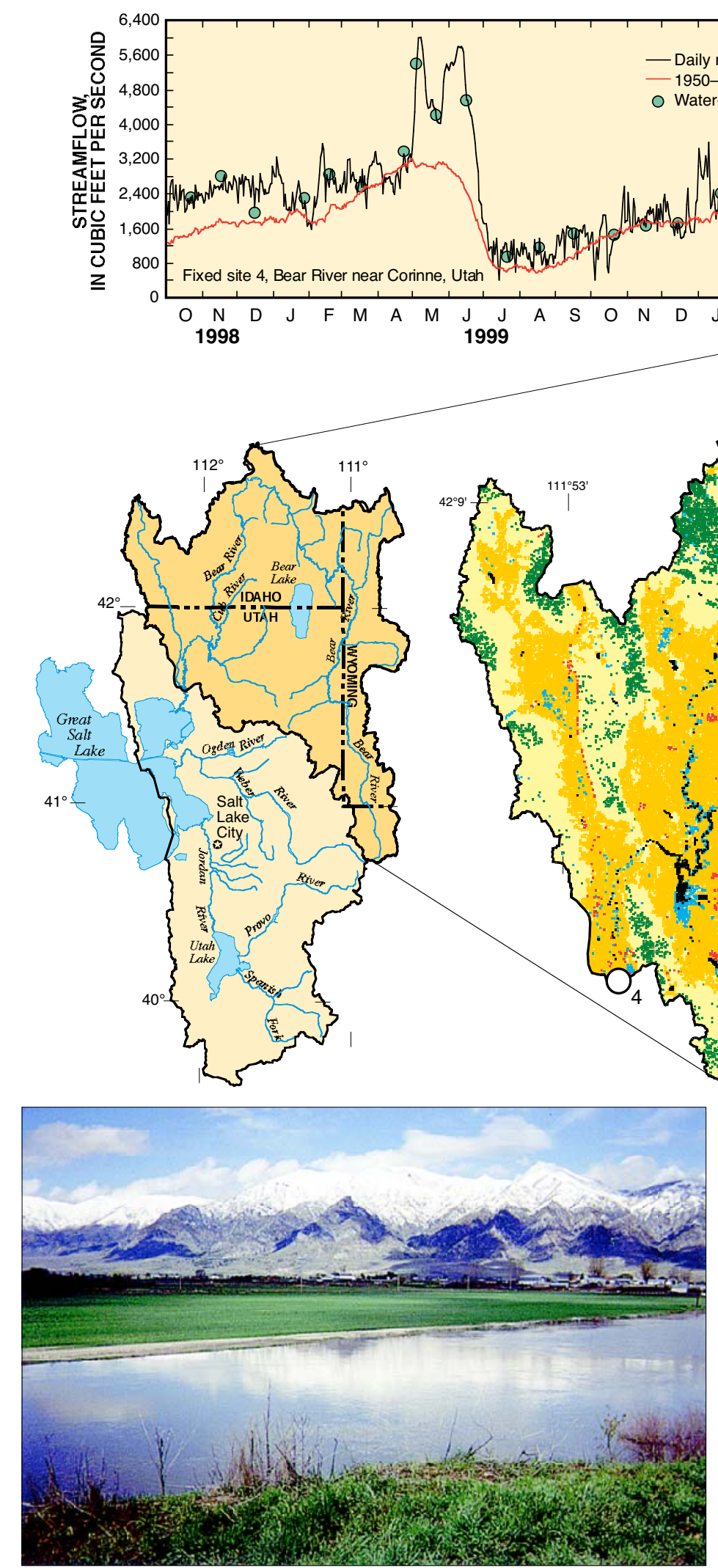

- Daily mean streamflow

-57, 1960-2000 mean daily streamflow

Water-quality sample 


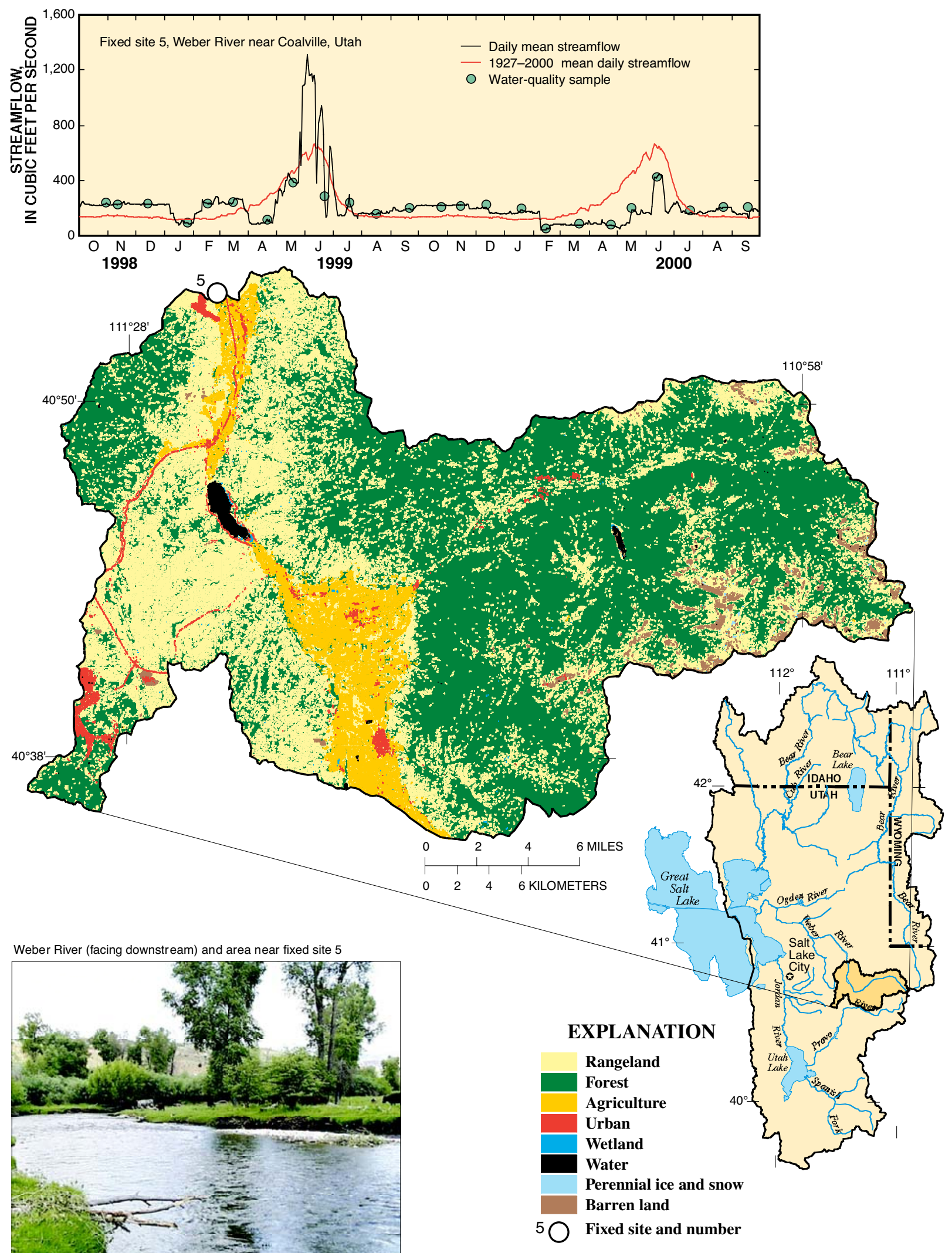

Figure 9. Land use/land cover, drainage basin location, and streamflow for the Weber River near Coalville, Utah. 

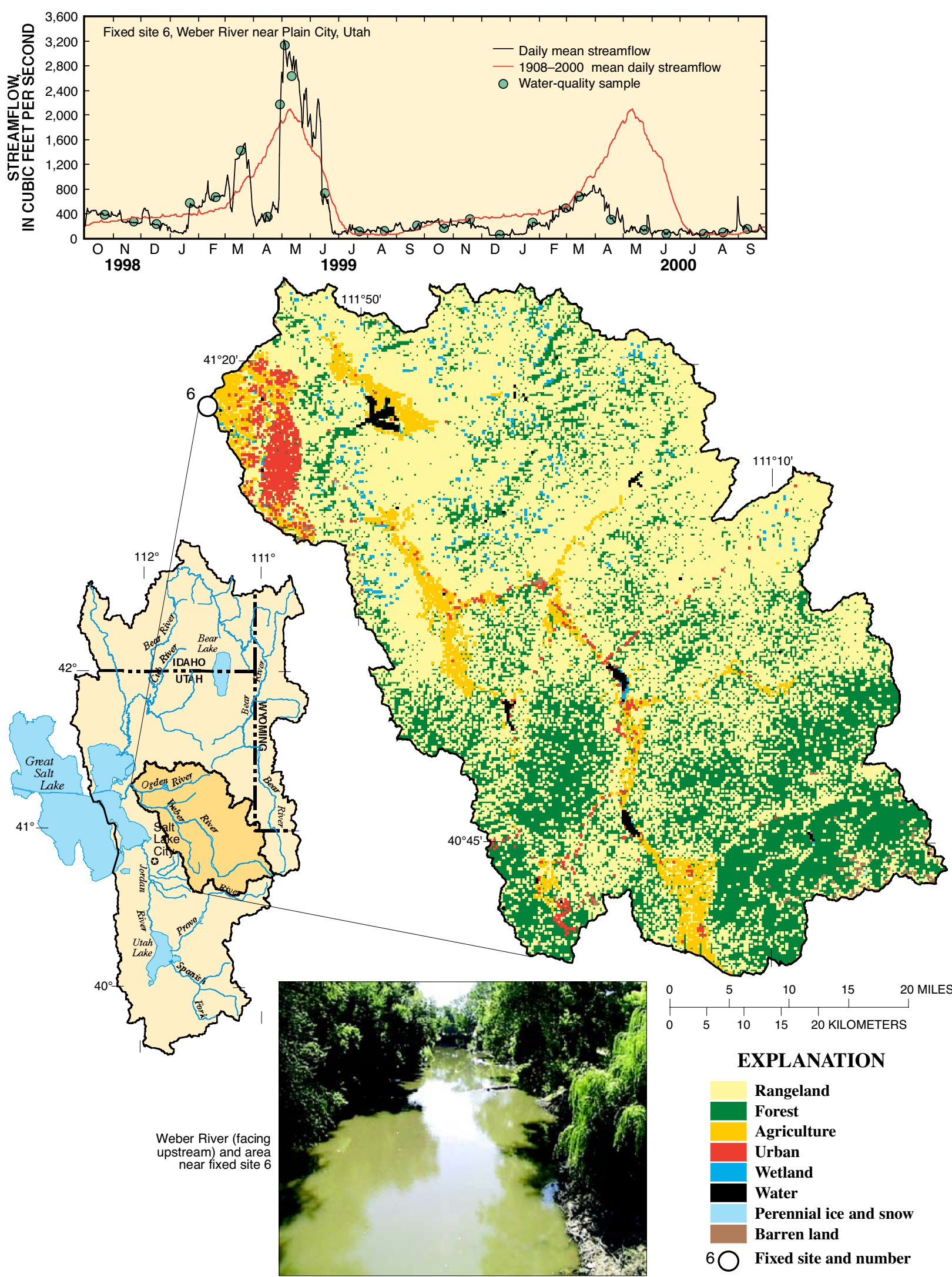

Figure 10. Land use/land cover, drainage basin location, and streamflow for the Weber River near Plain City, Utah. 


\section{Utah Lake/Jordan River Drainage Basin}

The Utah Lake/Jordan River drainage basin includes the Provo and Spanish Fork Rivers, which terminate in Utah Lake, and the Jordan River drainage basin. During 1995, irrigation for agriculture accounted for an estimated 70 percent of all water use, and public supply accounted for an estimated 26 percent of all water use in the Utah Lake/Jordan River drainage basin (Baskin and others, 2002). The Jordan River starts at the outflow from Utah Lake and flows northward through the Salt Lake City metropolitan area before discharging into Great Salt Lake. Inflow to Utah Lake is primarily affected by agricultural and urban land uses and imports from the Colorado River Basin as part of the Central Utah Project. About 15 percent of the total average annual surface-water runoff (1931-76) to Great Salt Lake is from the Jordan River. Most urban development and more than 75 percent of the population of Utah is along the Wasatch Front, extending north from Provo to Ogden and including the Jordan River drainage basin. Factors that affect the water quality of the Jordan River include urban and industrial uses and past mining and metal-processing activities.

Two sites were established on Little Cottonwood Creek, a tributary to the Jordan River, with the purpose of determining the effect of urban land use on water quality in the GRSL study unit (fig. 1). These sites bracket a reach of Little Cottonwood Creek that has a drainage area of $9 \mathrm{mi}^{2}$ that is nearly 100 percent urban land cover. The distance between the sites is about 5.7 mi. By using the data from water samples collected at both sites, effects of the urban land cover on water quality in Little Cottonwood Creek was evaluated.

\section{Little Cottonwood Creek at Crestwood Park}

Site 7, Little Cottonwood Creek at Crestwood Park, is 4.8 mi downstream from the mouth of Little Cottonwood Canyon. The drainage basin above site 7 is $36 \mathrm{mi}^{2}$ in area and lies within the Central Basin and Range and Wasatch and Uinta Mountains ecoregions. Land cover is mainly rangeland (35 percent), forest (46 percent), and urban (10 percent).

Snowmelt runoff dominates the streamflow at this site from about April through June. The rest of the year most of the water in Little Cottonwood Creek is withdrawn for the Metropolitan Water Treatment Plant near the canyon mouth, and flows are greatly reduced. Daily mean streamflow ranged from 0.1 to $359 \mathrm{ft}^{3} / \mathrm{s}$ (fig. 11). Twenty-nine water samples were collected for chemical analysis at site 7 , and the corresponding streamflow ranged from 0.2 to $227 \mathrm{ft}^{3} / \mathrm{s}$.

\section{Little Cottonwood Creek at Jordan River}

Site 8, Little Cottonwood Creek at Jordan River, is $0.7 \mathrm{mi}$ upstream from the confluence with the Jordan River. The drainage basin above site 8 is $45 \mathrm{mi}^{2}$ in area and lies within the Central Basin and Range and Wasatch and Uinta Mountains ecoregions. Land cover for the basin is mainly forest (37 percent), rangeland ( 29 percent), and urban (26 percent). A sharp demarcation between rangeland/forest land cover and urban land cover occurs near the Wasatch-Cache National Forest and Wasatch and Uinta Mountains ecoregion boundaries. Land use downstream from these boundaries is nearly 100 percent urban.

Site 8 is situated in, and downstream from, an urban area that consists mainly of recently developed, low density, residential land use. Water-quality influences at this site include runoff from urban land cover, runoff from historical metals-processing facilities within the urban area, historical mining in Little Cottonwood Canyon, and road-salting activities throughout the drainage basin.

Snowmelt runoff dominates the streamflow at this site from about April through June. Streamflow at this site consists mainly of irrigation return and ground-water discharge during the summer months. Daily mean streamflow ranged from 1.3 to $357 \mathrm{ft}^{3} / \mathrm{s}$ (fig. 12). Forty-five water samples were collected for chemical analysis, and corresponding streamflow ranged from 1.5 to $298 \mathrm{ft}^{3} / \mathrm{s}$.

\section{Red Butte Creek at Fort Douglas}

Site 9, Red Butte Creek at Fort Douglas, is in Red Butte Canyon, a Research Natural Area east of Salt Lake City in the Wasatch-Cache National Forest. The drainage basin above this site is $7.21 \mathrm{mi}^{2}$ in area and lies within the Wasatch and Uinta Mountains ecoregion. This site was selected as a reference site for range and forest land use, which account for nearly 100 percent of the land use in the basin. Red Butte Canyon is a closed and protected watershed. It is set aside primarily for research and education and is managed by the U.S. Forest Service. A detailed description of the basin and analysis of an extensive water-chemistry data set is available in Mast and Clow (2000). 


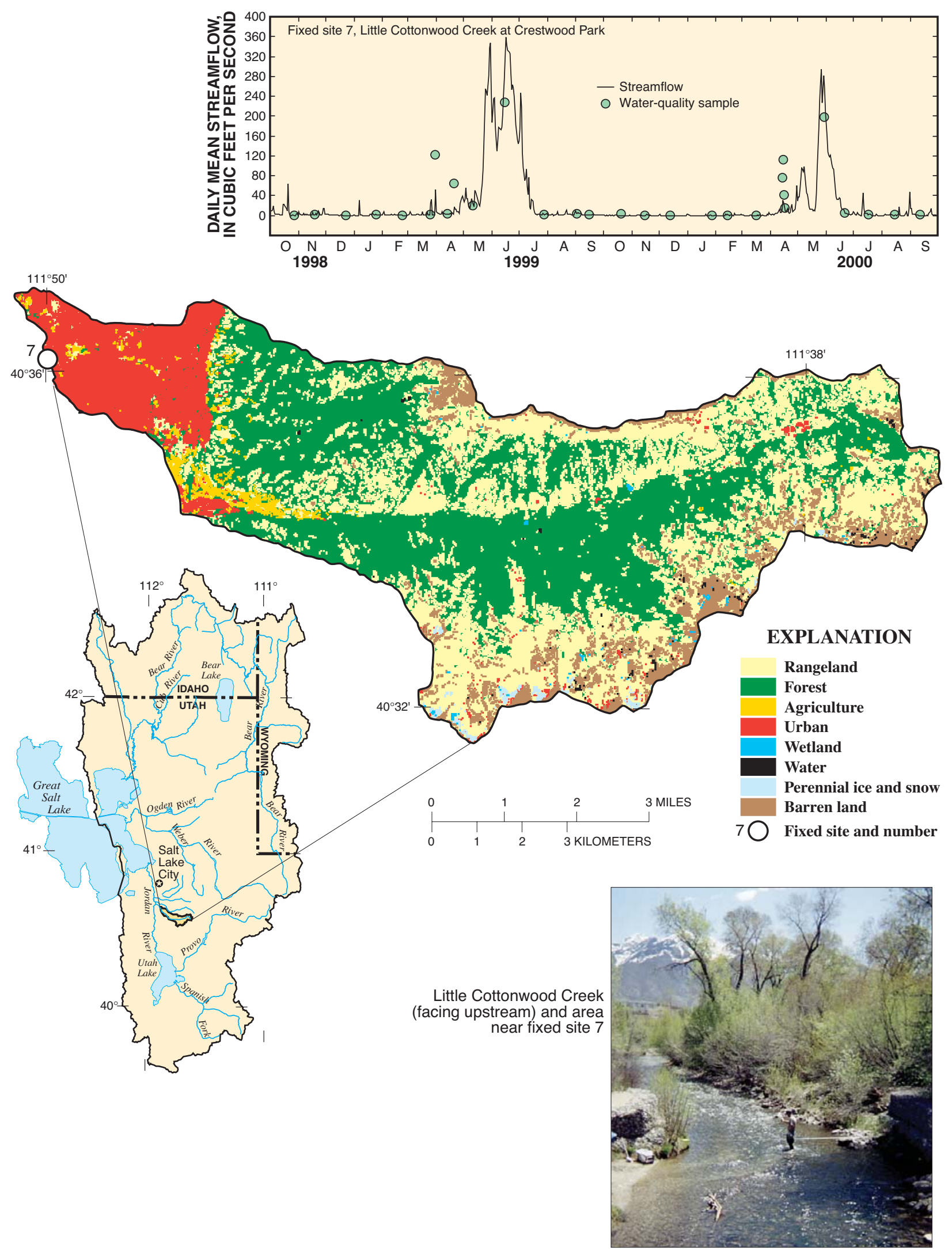

Figure 11. Land use/land cover, drainage basin location, and streamflow for Little Cottonwood Creek at Crestwood Park, Salt Lake City, Utah. 

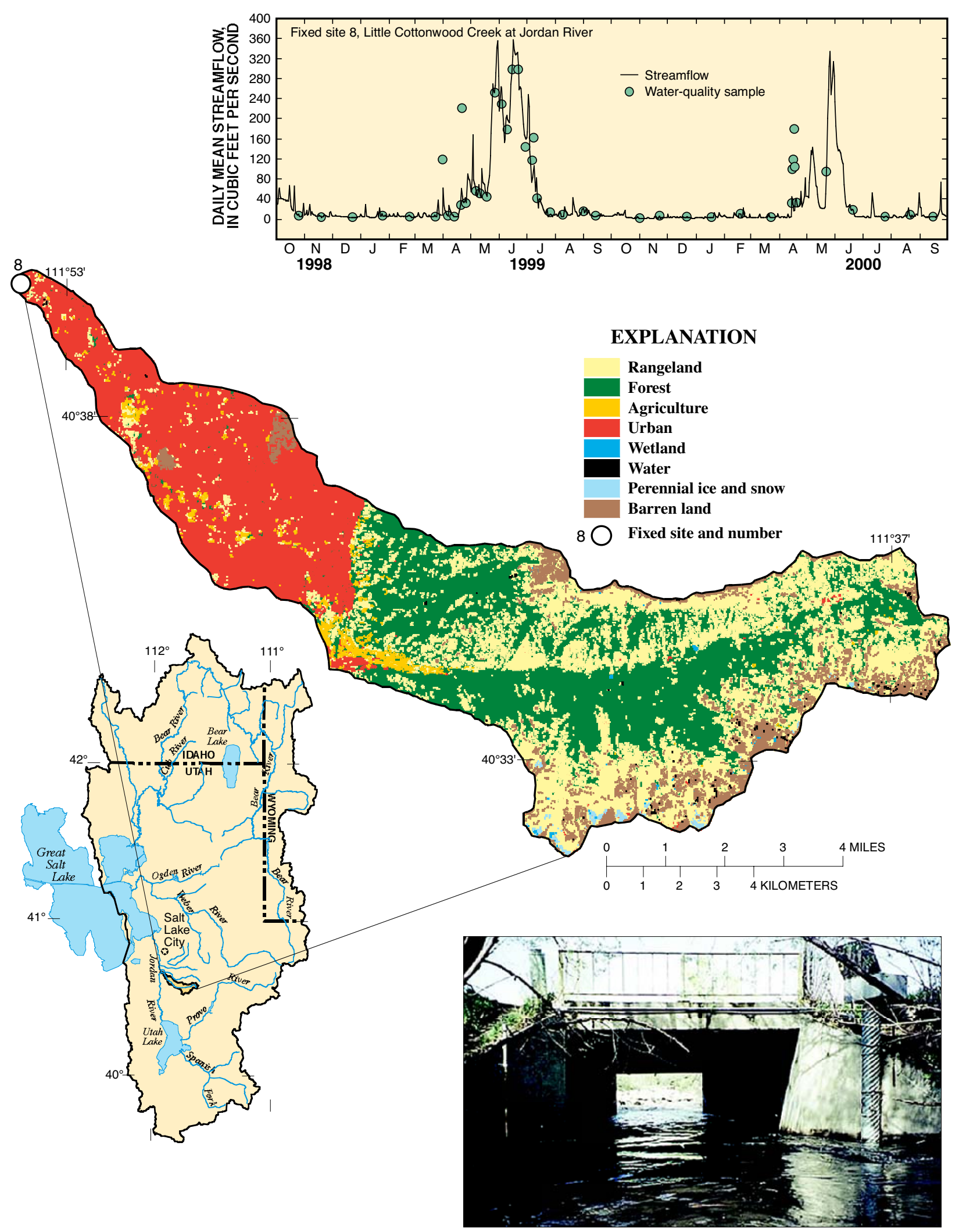

Little Cottonwood Creek (facing downstream) at fixed site 8

Figure 12. Land use/land cover, drainage basin location, and streamflow for Little Cottonwood Creek at Jordan River, Salt Lake City, Utah. 
Daily mean streamflow ranged from 0.7 to 22 $\mathrm{ft}^{3} / \mathrm{s}$ (fig.13). Twenty-seven water samples were collected at this site, and corresponding streamflow ranged from 1 to $20 \mathrm{ft}^{3} / \mathrm{s}$.

\section{Jordan River at Salt Lake City}

Site 10, Jordan River at Salt Lake City, was selected to represent the multiple land uses and physical settings in the Utah Lake/Jordan River drainage basin. The drainage basin above this site is about 3,508 $\mathrm{mi}^{2}$ in area and lies within the Central Basin and Range and Wasatch and Uinta Mountains ecoregions. Although land cover for the drainage basin is mainly forest (42 percent) and rangeland (40 percent), urban land uses ( 5 percent) probably have the largest effect on water quality. Two waste-water treatment plants upstream from this site discharge about 93,000 acre-ft of water annually to the Jordan River (Utah Department of Natural Resources, 1997a), which represents about 23 percent of the annual streamflow upstream from site 10 . Water quality at this site also is affected by historical mining.

Flow at site 10 is affected by regulation at Utah Lake and the Surplus Canal diversion. Site 10 is located about 0.2 mi below the Surplus Canal floodcontrol diversion, where most of the flow is diverted. The chemistry of water samples at site 10 is expected to be very similar to the chemistry of water from the Jordan River above the Surplus Canal diversion and of water from the Surplus Canal itself.

The daily mean streamflow of the Jordan River above the Surplus Canal diversion ranged from 228 to $2,270 \mathrm{ft}^{3} / \mathrm{s}$. Daily mean streamflow at site 10 ranged from 6.7 to $203 \mathrm{ft}^{3} / \mathrm{s}$ (fig. 14). Thirty-three water samples were collected at this site, and the corresponding streamflow ranged from 10 to $190 \mathrm{ft}^{3} / \mathrm{s}$. During reconstruction of the Surplus Canal diversion gates in August and September 1999, four fixedfrequency samples were collected at the Surplus Canal rather than at the Jordan River site and the corresponding streamflow ranged from 139 to 720 $\mathrm{ft}^{3} / \mathrm{s}$.

\section{WATER QUALITY}

The natural factors of physiography, geology, soils, climate, and hydrology largely determine the natural background quality of water. The cultural factors of population, manipulation of land cover, water use, and waste-management practices determine the human influence on water quality. Analysis of water samples collected at the fixed sites provides a tool to evaluate water quality at the time the samples are collected. Data from these water samples were used to evaluate differences in water quality at the sites over time or among sites. In many cases, box plots are used in this report to illustrate statistical characteristics of the data, including median, quartile range, and data range.

The concentrations of some trace metals, pesticides, and VOCs in water samples from the fixed sites were compared with Ambient Water Quality Criteria (AWQC) for aquatic organisms. These criteria are used as a basis for States to develop water-quality standards (U.S. Environmental Protection Agency, 1999a). In those cases where criteria representing both acute and chronic exposure were available, sample concentrations were compared to the chronic criteria. The AWQC for some metals was developed with respect to water hardness, with maximum exposure levels increasing as water hardness increases. Constituents of water samples at concentrations exceeding the AWQC could pose a threat to the health of aquatic organisms.

\section{Physical Properties, Dissolved Solids, and Alkalinity}

Measurements of alkalinity, streamflow, dissolved oxygen (DO), $\mathrm{pH}$, specific conductance, and water temperature were made in the field each time samples were collected at a site (table 4). Continuous water-temperature measurements were made at all sites. Continuous specific-conductance measurements were made at sites $3,7,8,9$, and 10. Daily streamflow, specific-conductance, and water-temperature values were published in Herbert and others, (2000, 2001, and 2002). 

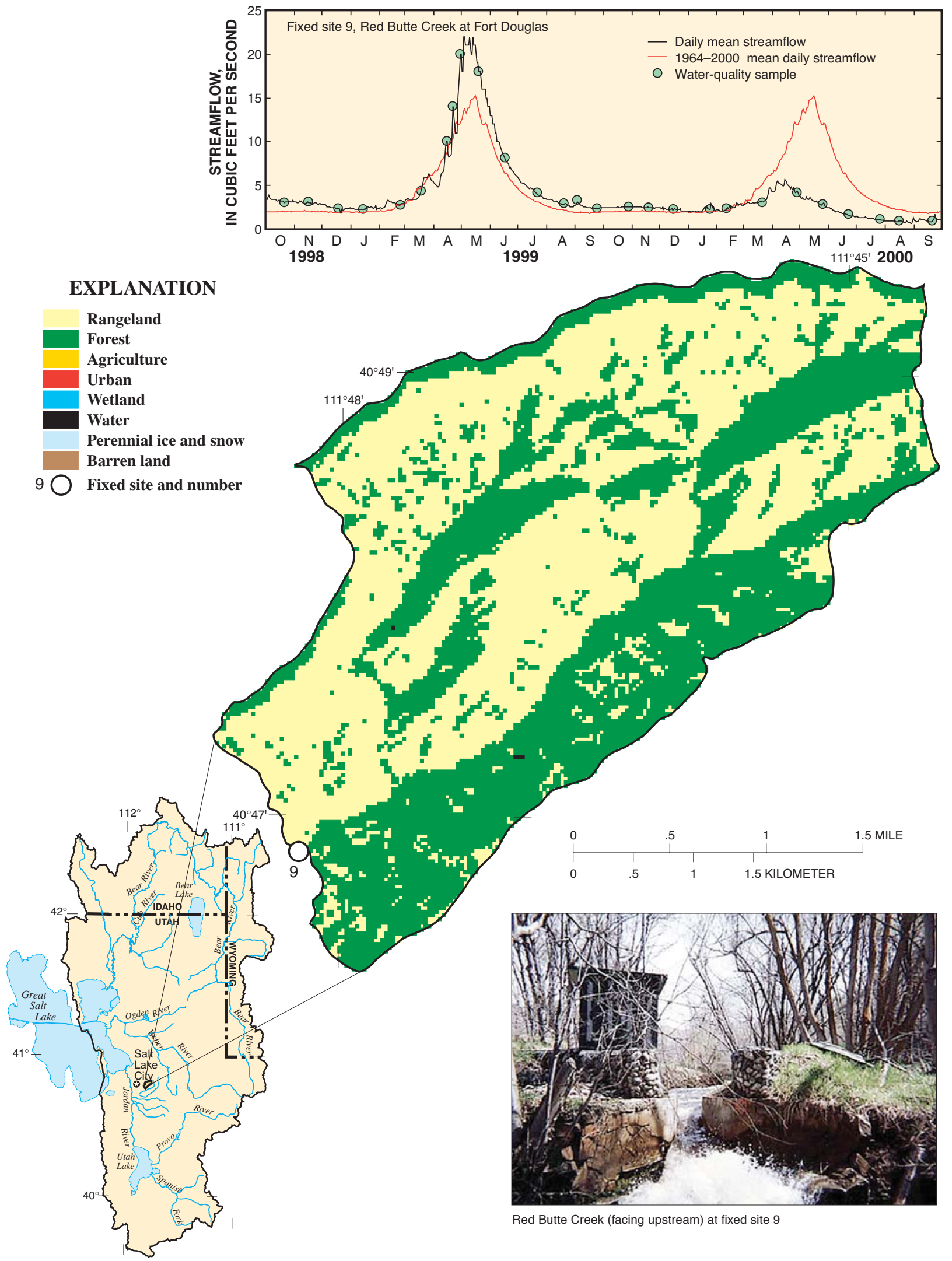

Figure 13. Land use/land cover, drainage basin location, and streamflow for Red Butte Creek at Fort Douglas, near Salt Lake City, Utah. 


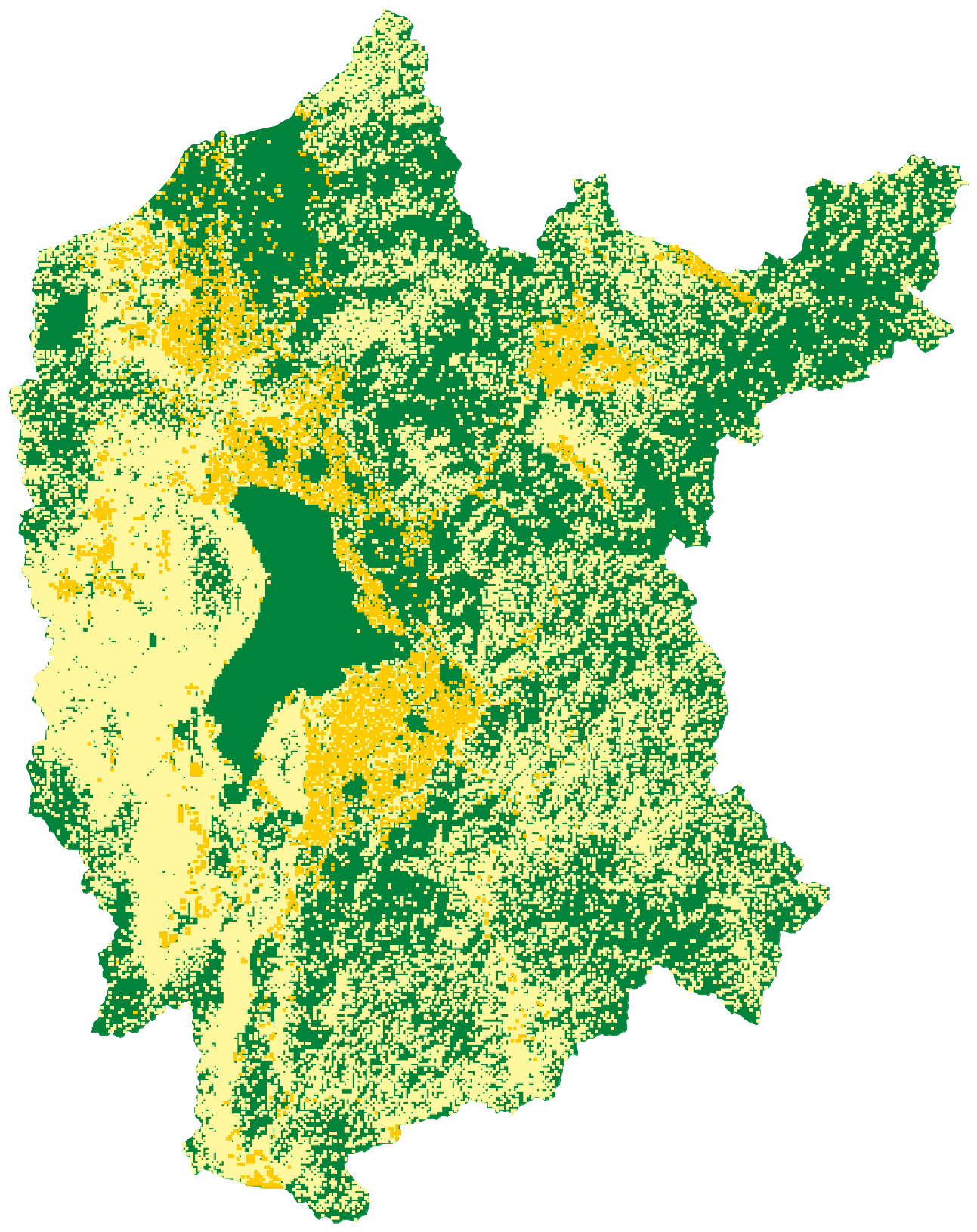

Figure 14. Land use/land cover, drainage basin location, and streamflow for the Jordan River at Salt Lake City, Utah. 
Table 4. Minimum reporting level of physical properties and chemical constituents measured at fixed sites in the Great Salt Lake Basins study unit [mg/L, milligrams per liter; $\mu \mathrm{g} / \mathrm{L}$, micrograms per liter]

\begin{tabular}{ccc}
\hline \multicolumn{1}{c}{ Activity } & $\begin{array}{c}\text { Physical property or } \\
\text { chemical constituent }\end{array}$ & $\begin{array}{c}\text { Minimum reporting } \\
\text { level }\end{array}$ \\
\hline Field measurement &
\end{tabular}

Field measurement

\section{Physical properties}

Discharge

Specific conductance

$\mathrm{pH}$

Water temperature

Dissolved oxygen

Alkalinity

Laboratory analyses
0.0

1

1

.1

.1
Cubic foot per second

Microsiemen per centimeter at 25 degrees Celsius

Standard unit

Degree Celsius

$\mathrm{mg} / \mathrm{L}$

$\mathrm{mg} / \mathrm{L}$

Calcium, dissolved

Chloride, dissolved

Dissolved solids, residue on evaporation

Fluoride, dissolved

Magnesium, dissolved

Manganese, dissolved

Potassium, dissolved

Silica, dissolved

Sodium, dissolved

Sulfate, dissolved

Nitrogen, ammonia, dissolved

Nitrogen, nitrite, dissolved

Nitrogen, nitrite plus nitrate, dissolved

Nitrogen, organic, plus ammonia, dissolved

Nitrogen, organic, plus ammonia, total

Phosphorus, orthophosphate, dissolved

Phosphorus, dissolved

Phosphorus, total

Dissolved

Suspended

Aluminum, dissolved

Antimony, dissolved

Arsenic, dissolved

Barium, dissolved

Beryllium, dissolved

Boron, dissolved

Cadmium, dissolved

Chromium, dissolved

Cobalt, dissolved

Copper, dissolved

Iron, dissolved

Lead, dissolved

Lithium, dissolved

Molybdenum, dissolved

Nickel, dissolved

Selenium, dissolved

Silver, dissolved

Strontium, dissolved

Thallium, dissolved

Uranium, dissolved

Vanadium, dissolved

Zinc, dissolved

Major ions

$\begin{array}{cc}.02 & \mathrm{mg} / \mathrm{L} \\ .1 \text { and } .29 & \mathrm{mg} / \mathrm{L} \\ 10 & \mathrm{mg} / \mathrm{L} \\ .1 & \mathrm{mg} / \mathrm{L} \\ .004 \text { and } .014 & \mathrm{mg} / \mathrm{L} \\ 3.0 \text { and } 2.2 & \mu \mathrm{g} / \mathrm{L} \\ .1 \text { and } .24 & \mathrm{mg} / \mathrm{L} \\ .05 \text { and } .09 & \mathrm{mg} / \mathrm{L} \\ .06 \text { and } .09 & \mathrm{mg} / \mathrm{L} \\ .1 \text { and } .31 & \mathrm{mg} / \mathrm{L}\end{array}$

Nutrients

$.02 \mathrm{mg} / \mathrm{L}$

$.01 \mathrm{mg} / \mathrm{L}$

$.05 \mathrm{mg} / \mathrm{L}$

$.1 \mathrm{mg} / \mathrm{L}$

$.1 \mathrm{mg} / \mathrm{L}$

$01 \mathrm{mg} / \mathrm{L}$

004 and $.008 \quad \mathrm{mg} / \mathrm{L}$

.004 and $.006 \quad \mathrm{mg} / \mathrm{L}$

Organic carbon

.1 and $.33 \mathrm{mg} / \mathrm{L}$

.1 and $.2 \mathrm{mg} / \mathrm{L}$

Trace elements

$1 \mu \mathrm{g} / \mathrm{L}$

$1 \mu \mathrm{g} / \mathrm{L}$

1 and $2 \quad \mu \mathrm{g} / \mathrm{L}$

$1 \mu \mathrm{g} / \mathrm{L}$

$1 \mu \mathrm{g} / \mathrm{L}$

$6 \mu \mathrm{g} / \mathrm{L}$

$1 \mu \mathrm{g} / \mathrm{L}$

1 and $8 \quad \mu \mathrm{g} / \mathrm{L}$

$1 \mu \mathrm{g} / \mathrm{L}$

$1 \mu \mathrm{g} / \mathrm{L}$

$0 \quad \mu \mathrm{g} / \mathrm{L}$

$\mu \mathrm{g} / \mathrm{L}$

$\mu \mathrm{g} / \mathrm{L}$

$\mu \mathrm{g} / \mathrm{L}$

$\mu \mathrm{g} / \mathrm{L}$

$\mu \mathrm{g} / \mathrm{L}$

$\mu \mathrm{g} / \mathrm{L}$

$\mu \mathrm{g} / \mathrm{L}$

$\mu \mathrm{g} / \mathrm{L}$

$\mu \mathrm{g} / \mathrm{L}$

$\mu \mathrm{g} / \mathrm{L}$

$\mu \mathrm{g} / \mathrm{L}$ 
Table 4. Minimum reporting level of physical properties and chemical constituents measured at fixed sites in the Great Salt Lake Basins study unitContinued

\begin{tabular}{llcl}
\hline \multicolumn{1}{c}{ Activity } & \multicolumn{1}{c}{$\begin{array}{c}\text { Physical property or } \\
\text { chemical constituent }\end{array}$} & $\begin{array}{c}\text { Minimum reporting } \\
\text { level }\end{array}$ & Unit \\
\hline Datalogger & Suspended & 1 & $\mathrm{mg} / \mathrm{L}$ \\
& $\begin{array}{l}\text { Streamflow, 15-minute interval } \\
\text { Specific conductance, 15-minute interval } \\
\text { Water temperature, 15-minute interval }\end{array}$ & .01 & $\begin{array}{l}\text { Cubic foot per second } \\
\text { Microsiemen per centimeter at 25 degrees Celsius } \\
\text { Degree Celsius }\end{array}$ \\
\hline
\end{tabular}

The specific-conductance value of water samples from the sites ranged from $4,870 \mu \mathrm{S} / \mathrm{cm}$ at Bear River near Corinne (site 4) to $111 \mu \mathrm{S} / \mathrm{cm}$ at Little Cottonwood Creek at Crestwood Park (site 7). The highest median specific-conductance value of water samples was $1,320 \mu \mathrm{S} / \mathrm{cm}$ at site 10 , Jordan River at Salt Lake City (fig. 15). Streamflow components contributing to the high median specific-conductance value calculated for this site include discharge from Utah Lake, effluent from waste-water treatment plants, and inflow from tributary streams that drain urban areas. Specific-conductance values and dissolvedsolids concentration measured in samples from the GRSL study-unit sites correlate very well. The coefficient of determination $\left(\mathrm{R}^{2}\right)$ when all fixed-site specific-conductance and dissolved-solids measurements were compared was 0.99 . Three measurements of specific-conductance values above $4,000 \mu \mathrm{S} / \mathrm{cm}$ were made at site 4 during June to August 2000 when streamflow was very low. Site 8 , Little Cottonwood Creek at Jordan River, had the largest range of specific-conductance values; a maximum of $4,020 \mu \mathrm{S} / \mathrm{cm}$ and a minimum of $200 \mu \mathrm{S} / \mathrm{cm}$.

Dissolved-solids concentration was lowest at most sites during March to June, when snowmelt runoff was a major streamflow component (fig. 16).

Dissolved-solids concentration was highest at most sites from July through October, when water with a lower dissolved-solids concentration was removed at upstream diversions and irrigation return was a major streamflow component. When grouped by basin, median dissolved-solids concentrations were highest at sites with mixed land uses (sites 4, 6, and 10). Site 10 had the highest median concentration of dissolved solids for each of the periods shown in figure 16. Throughout the study period, site 4 had the largest range of dissolved-solids concentration, from 339 to $2,750 \mathrm{mg} / \mathrm{L}$. Rangeland and forest sites in all three
GRSL river systems generally had low concentrations (less than $500 \mathrm{mg} / \mathrm{L}$ ) of dissolved solids throughout the year. Dissolved-solids concentrations at site 8, Little Cottonwood Creek at Jordan River, generally were high except when runoff from mountain snowmelt or summer rainstorms were large components of streamflow (fig. 17). Site 8 had the second highest median concentration of dissolved solids during two of the periods shown in figure 16. High dissolved-solids concentrations at this site were likely a result of road salting and inflows from subsurface drains.

Irrigation is the primary water use in the GRSL study unit. Utah waters protected for agricultural uses, such as irrigation of crops and stock watering, need a dissolved-solids concentration of less than $1,200 \mathrm{mg} / \mathrm{L}$ to meet the beneficial-use designation (Utah Department of Administrative Services, 2003). Five of 290 samples from the sites exceeded a concentration of $1,200 \mathrm{mg} / \mathrm{L}$ (fig. 16): three samples from site 4 during the summer of 2000, and one sample each from sites 7 and 8 . High dissolved-solids concentrations at sites 7 and 8 were associated with winter storm runoff. Samples collected for dissolved-solids concentration during this study indicate that water at the sites is generally not limited in its use for agricultural purposes, except for parts of the lower Bear River during extremely low flows.

Streams in the GRSL study unit generally have a $\mathrm{pH}$ near the upper range of natural water (6.5 to 8.5) described by Hem (1992) (fig. 15). The highest $\mathrm{pH}$ measured in water samples from the sites was 8.9 at site 5; the lowest was 7.1 at site 10 . The median $\mathrm{pH}$ of all samples from the sites was 8.2. Water at urban site 8 and mixed-land-use sites 6 and 10 had the lowest median $\mathrm{pH}$; rangeland/forest sites 2 and 5 had the highest median $\mathrm{pH}$ at 8.5 . 

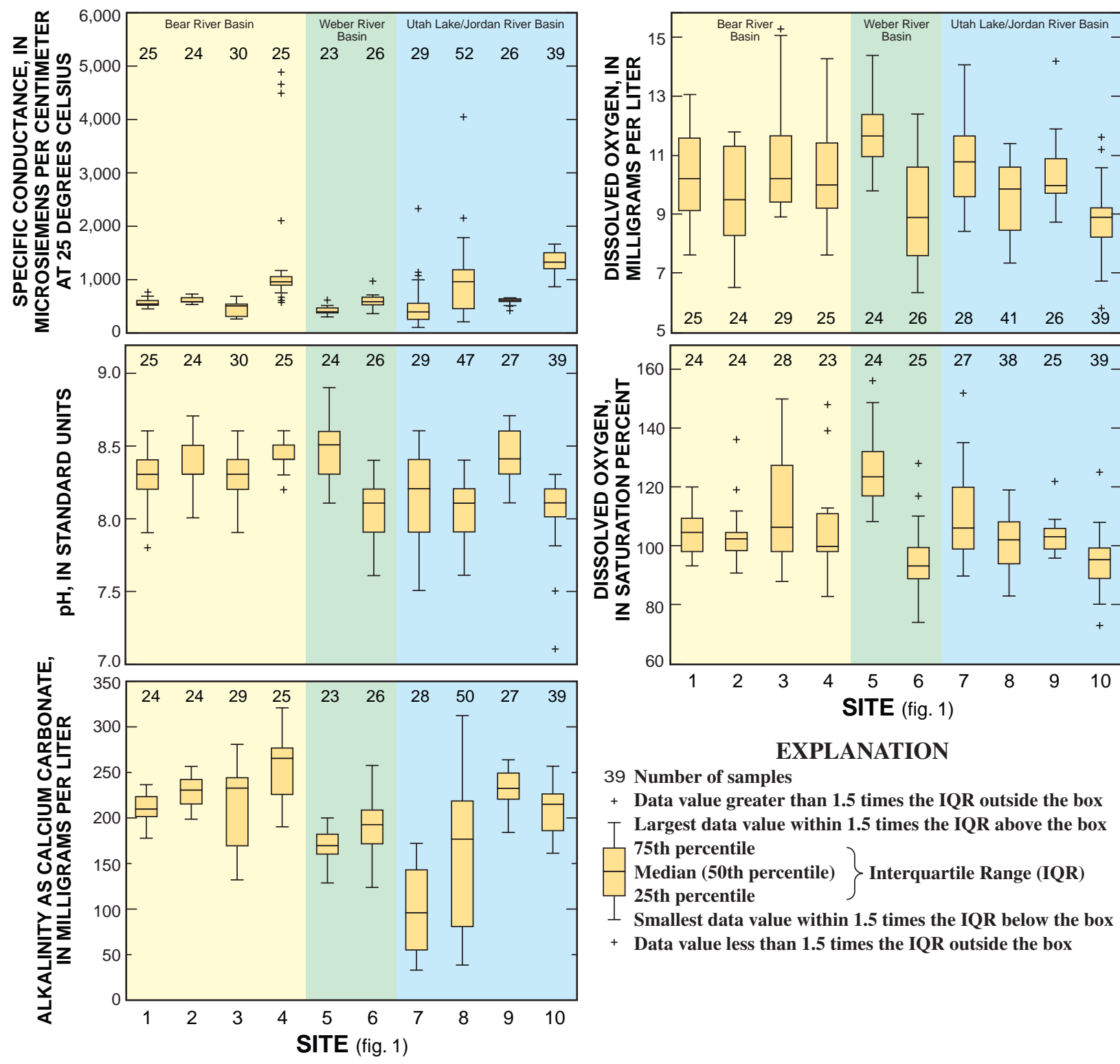

Figure 15. Specific-conductance value, pH, alkalinity, and dissolved oxygen in water samples from fixed sites in the Great Salt Lake Basins study unit. 


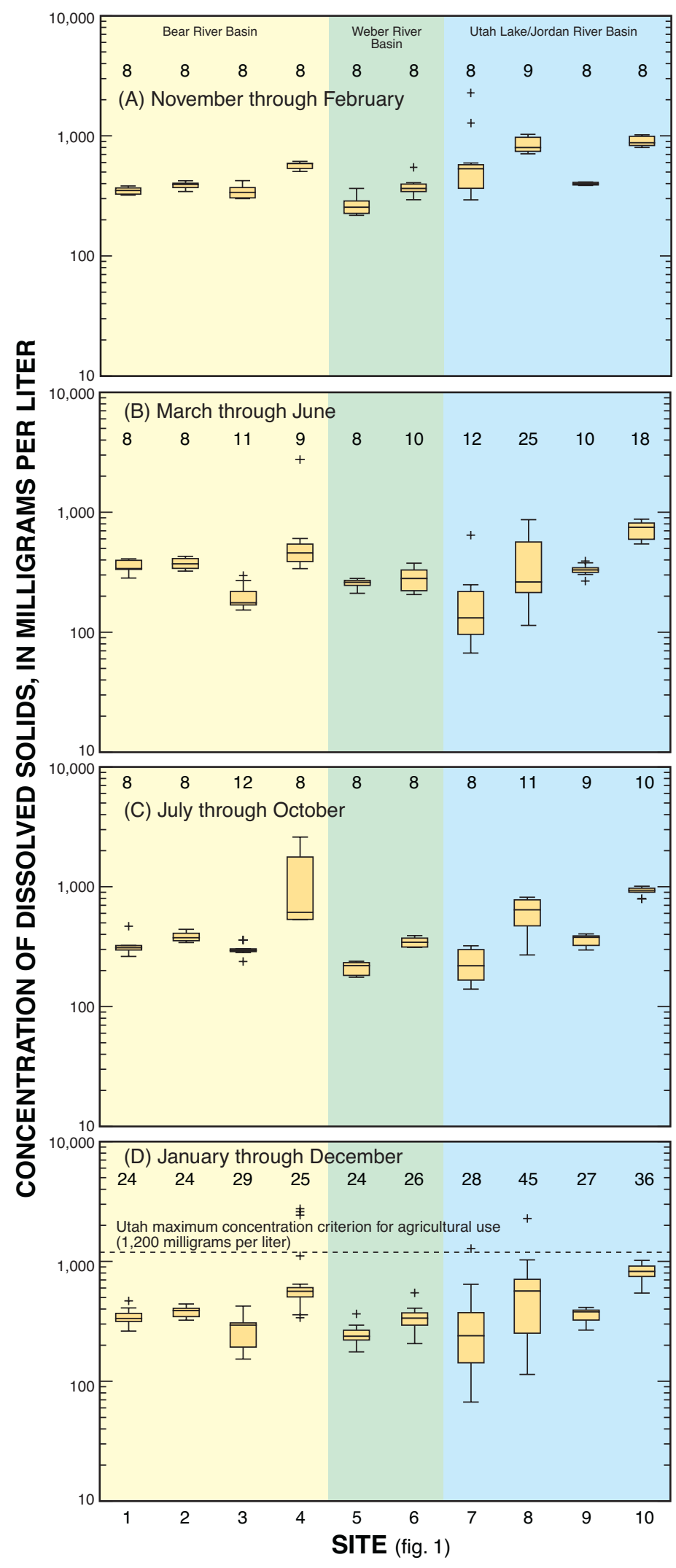

\section{EXPLANATION}

8 Number of samples

+ Data value greater than 1.5 times the IQR outside the box

Targest data value within 1.5 times the IQR above the box

75th percentile

$\left.\begin{array}{l}\text { Median (50th percentile) } \\ \text { 25th percentile }\end{array}\right\}$ Interquartile Range (IQR)

Smallest data value within 1.5 times the IQR below the box

+ Data value less than 1.5 times the IQR outside the box

Figure 16. Range and distribution of dissolved solids in water samples from fixed sites during (A) November through February, (B) March through June (C) July through October, and (D) January through December, Great Salt Lake Basins study unit. 


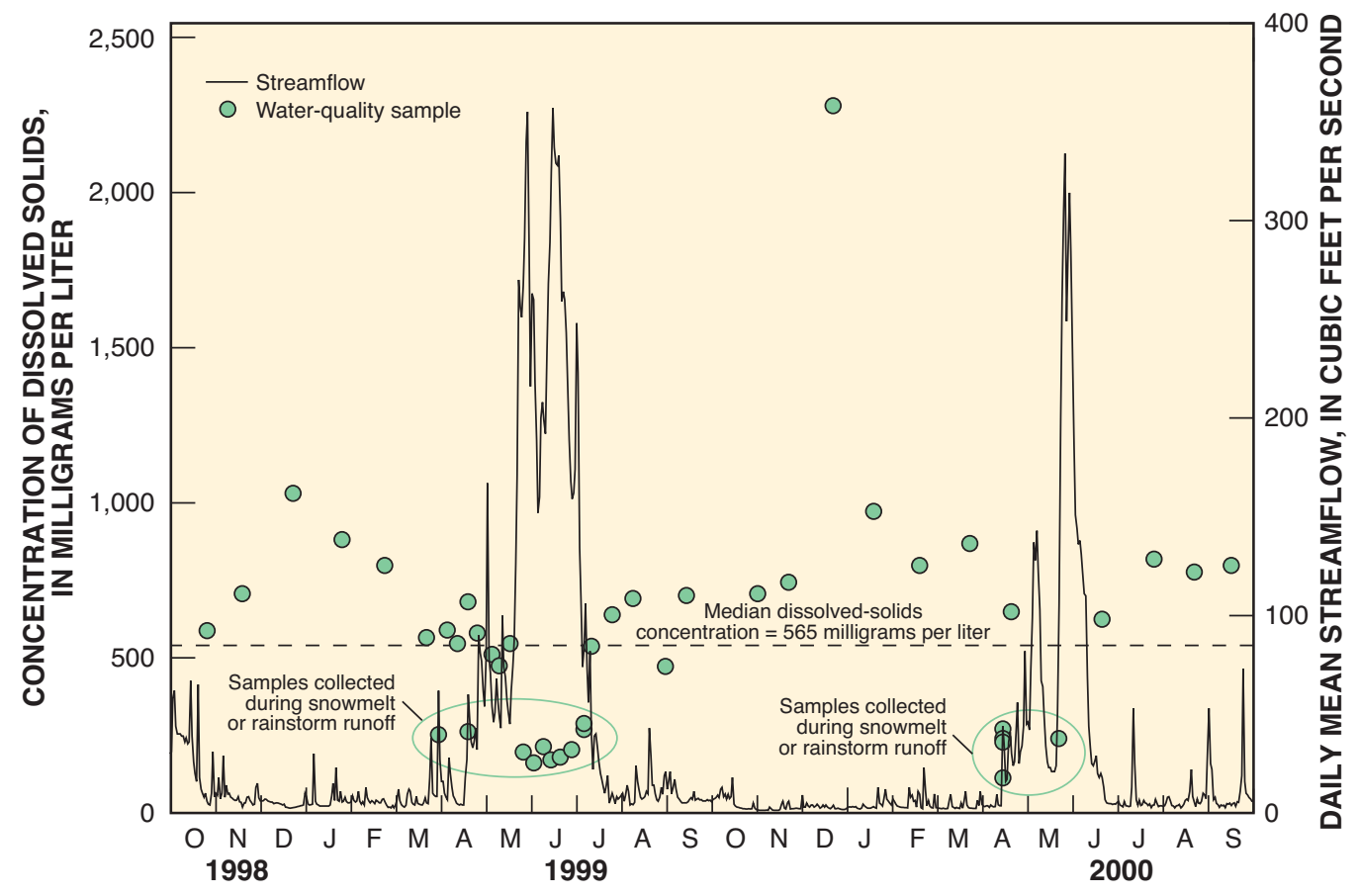

Figure 17. Dissolved-solids concentration and streamflow at site 8, Little Cottonwood Creek at Jordan River, Salt Lake City, Utah.

Water temperature was monitored continuously at the sites. There are gaps in the water-temperature record for most sites because of malfunctions or loss of equipment; however, eight of the sites have watertemperature data for more than 85 percent of the study period. Sites 4 and 5 have water-temperature data for about 60 percent of the study period. The data gaps, in most cases, did not preclude comparisons of water temperature among sites. Water temperatures were slightly warmer at most sites during WY 2000 than in WY 1999 because of lower flows and warmer air temperatures. Daily water temperature generally increased in each GRSL river basin from upstream to downstream sites (fig. 18). The increase in water temperature probably was a result of differences in altitude, land use, streamflow, and regulation.

Mean daily water temperature followed a similar pattern at all of the fixed sites on the Bear River with near-freezing temperatures at most sites during winter and near or above $20^{\circ} \mathrm{C}$ during the summer. Because it is in a smaller subbasin with a different flow regime, the Cub River near Richmond (site 3) has a slightly different temperature pattern than that of the Bear River sites. Winter and spring water temperatures are slightly warmer and the effect of snowmelt is more pronounced, causing water temperatures in May and June to be colder than at the other sites in the Bear River basin. The Bear River near Corinne (site 4) had the highest daily temperatures, as high as $27.7^{\circ} \mathrm{C}$.

The few data for the Weber River near Coalville (site 5) indicate that releases from upstream reservoirs moderate the water temperature at this site, resulting in winter temperatures several degrees above freezing and summer temperatures well below $20^{\circ} \mathrm{C}$. Daily water temperatures at the Weber River near Plain City (site 6) were warmer in both summer and winter than those at upstream site 5 . 

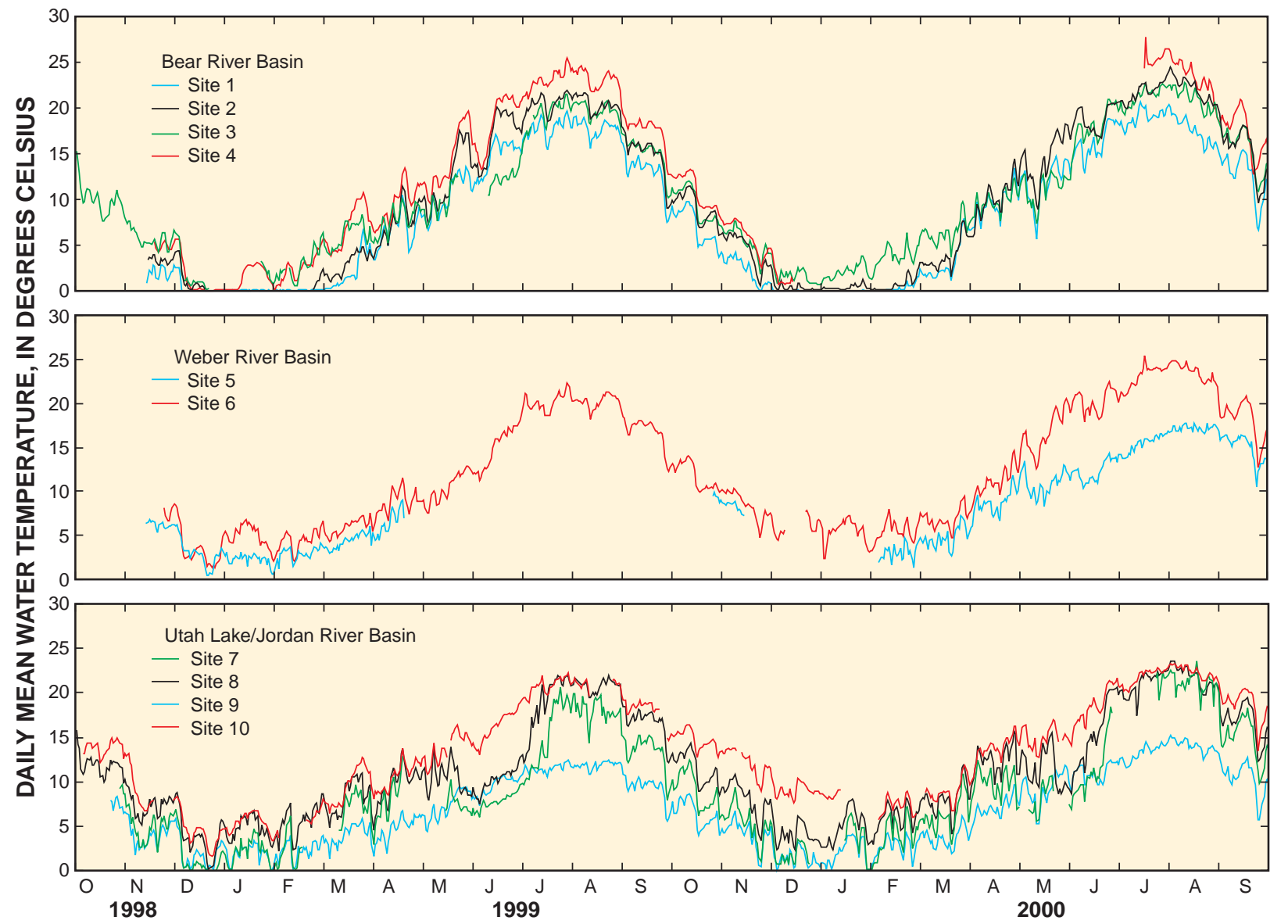

Figure 18. Daily mean water temperature at fixed sites in the Great Salt Lake Basins study unit.

Daily mean water temperature at site 9 on Red Butte Creek was, on average, $4.5^{\circ} \mathrm{C}$ cooler than at site 8 on Little Cottonwood Creek, and $6.6^{\circ} \mathrm{C}$ cooler than at site 10 on the Jordan River. Daily water temperatures generally were 7 to $10^{\circ} \mathrm{C}$ cooler at site 9 , relative to sites 8 and 10, during July to September. The cooler water temperatures at site 9 may be attributed to cooler air temperature, more riparian cover and ground-water inflow, and minimal effect from urbanization. A substantial decrease in daily water temperature occurred at sites 7 and 8 during May and June as snowmelt became the primary source of flow. Water temperatures at sites 8 and 10 generally were much warmer during the winter than those at the other sites in the Jordan River basin, possibly because of the inflow of warmer water from urban runoff or waste-water treatment plants.
DO concentration at most sites at the time of sample collection generally was at or above saturation and ranged in concentration from 5.8 to $15.3 \mathrm{mg} / \mathrm{L}$. DO concentration at site 6, Weber River near Plain City, and site 10, Jordan River at Salt Lake City, generally was less than saturated at the time of sample collection (fig. 15). Lower DO concentration at sites 6 and 10 probably was a result of increased biological oxygen demand from microbial degradation of organic matter, as well as less natural aeration because of minimal channel slope and stream turbulence. The highest median DO saturation percent was 124 at site 5, Weber River near Coalville. The stream reach near site 5 has a fairly steep gradient to support aeration, flow is generally cold and clear, and there is abundant algal and macrophytic growth.

Streams and rivers in the GRSL study unit are typically alkaline. Alkalinity generally was higher in 
the Bear River basin than in other basins in the study unit, increasing from upstream sites to downstream sites (fig. 15). Most alkalinity (as calcium carbonate $\left(\mathrm{CaCO}_{3}\right)$ ) concentrations in this basin were greater than $200 \mathrm{mg} / \mathrm{L}$. Site 4, the mixed-land-use site near the mouth of the Bear River basin, had the highest alkalinity measured, $321 \mathrm{mg} / \mathrm{L}$; and the highest median alkalinity concentration among the fixed sites, 273 $\mathrm{mg} / \mathrm{L}$. Alkalinity at the Weber River sites was lower than that at Bear River sites and increased slightly from upstream to downstream. Most alkalinity concentrations from this basin were less than 200 mg/L. Site 7, an urban site on Little Cottonwood Creek, had the lowest alkalinity measured, $31 \mathrm{mg} / \mathrm{L}$, and the lowest median alkalinity concentration among the fixed sites, $94 \mathrm{mg} / \mathrm{L}$. Many of the samples from sites 7 and 8 on Little Cottonwood Creek had large components of snowmelt runoff or rainstorm runoff, both having low dissolved-solids concentrations. The median alkalinity concentration at site 9 on Red Butte Creek was 231 $\mathrm{mg} / \mathrm{L}$, higher than that at other sites in the Jordan River basin. Calcite deposits in the stream reach near site 9 are evidence of the high calcium carbonate concentration in the stream.

\section{Major lons}

Major-ion chemistry at GRSL sites is affected by environmental and anthropogenic influences and varies by basin, season, and predominant land use/land cover. The similar geology in the common headwater areas of the Uinta Mountains of the Bear, Weber, and Utah Lake/Jordan River basins influences the major-ion chemistry of water in each of the basins.

Chemical analysis of water samples from site 1 in the Bear River basin, site 5 in the Weber River basin, and site 9 in the Utah Lake/Jordan River basin indicates that the water from each site was of a similar calcium bicarbonate type (fig. 19). These three sites are the nearest to the headwaters of their respective basins, and the major-ion chemistry is mostly the result of dissolution of minerals in the mountain block. Because of their location, these sites provide a reference for comparing downstream sites in their respective basins. Seasonal changes in major-ion chemistry at these sites were small, with some dilution from snowmelt during spring runoff and some increased concentration of solutes during base flow.

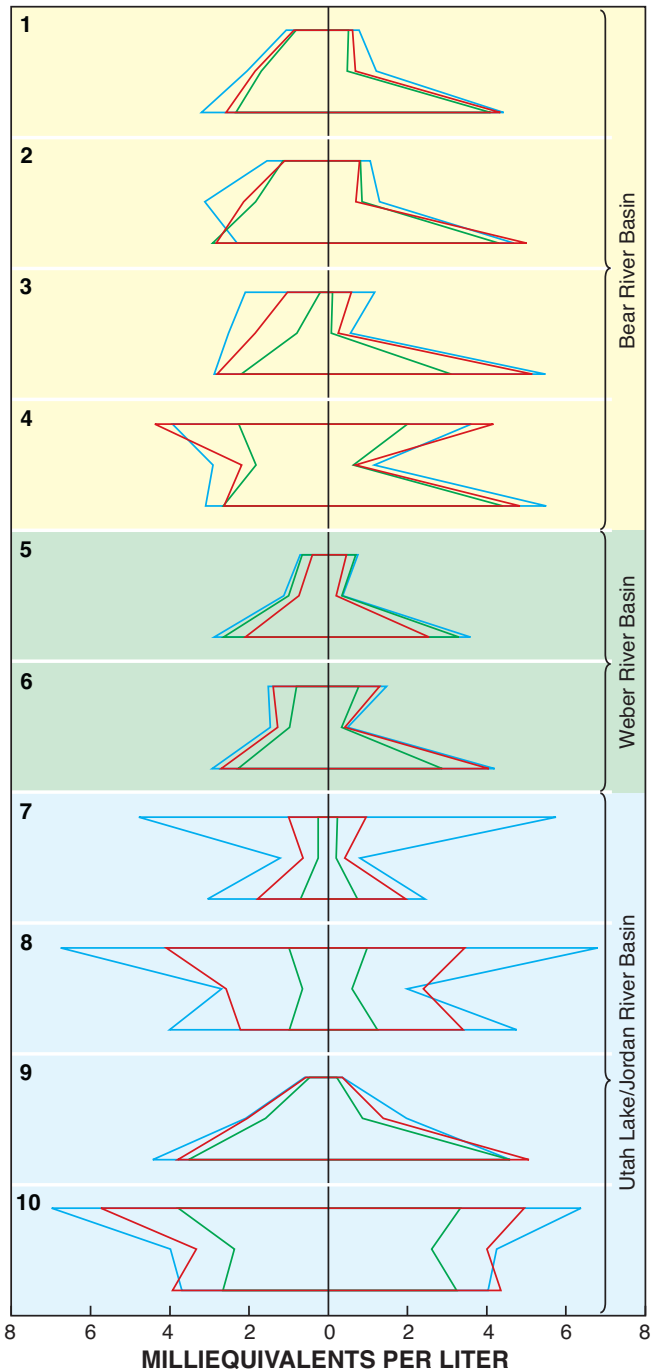

\section{EXPLANATION}

Stiff diagram

Winter base flow (February 1999)

_ Snowmelt runoff (May-June 1999)

Summer base flow (July 1999)

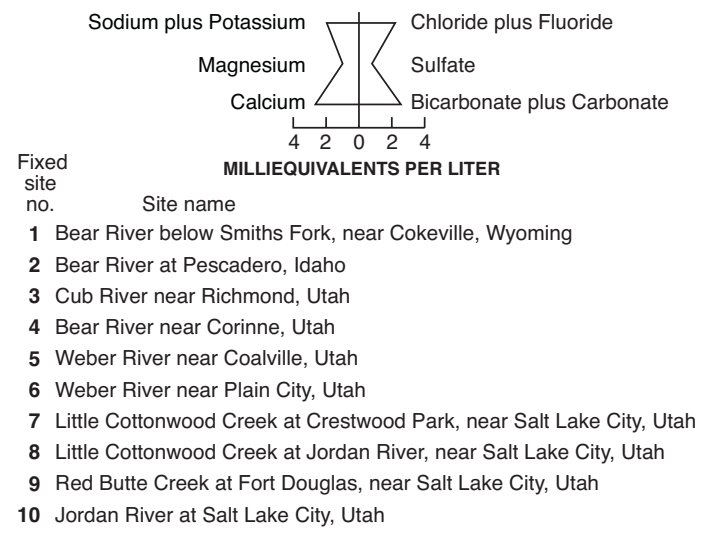

Figure 19. Chemical composition of water samples collected during winter base flow, snowmelt, and summer base flow conditions at fixed sites in the Great Salt Lake Basins study unit, 1999 water year. 
The predominant land use/land cover associated with sites 1 and 2 is rangeland. The major-ion chemistry of water samples collected from these sites is very similar, indicating the dissolution of calcium carbonate type rock and soils. The winter base-flow sample from site 2 was enriched with magnesium and depleted in calcium. Ground water discharged to the stream in the vicinity of Bear Lake, or Bear Lake water itself (both enriched with magnesium), may have been components of streamflow during winter base-flow conditions and contributed to magnesium enrichment.

Water samples from site 3, an agriculture indicator site on the Cub River, had concentrations of major ions similar to those from rangeland sites 1 and 2 during summer base-flow conditions, lower concentrations during snowmelt runoff, and were enriched in sodium and chloride in the winter baseflow sample (fig. 19). Although potassium concentration was much lower than sodium concentration in water samples from the sites in the Bear River basin, potassium was enriched in water samples from site 3 . The median potassium to sodium ratio in water samples from most sites varied from 0.04 to 0.06 (fig. 20). The median potassium to sodium ratio in samples from site 3 , however, was 0.15 . Runoff and leaching from fertilized agricultural areas may be the cause of potassium enrichment at site 3 .

Site 4, Bear River near Corinne, is a mixed-landuse site near the outlet of the Bear River basin. Water samples from site 4 were enriched with sodium, chloride, and potassium during all flow regimes, probably because of solutes in inflow from the Malad River and Salt Creek, and in irrigation return flow.

Calcium and bicarbonate are the dominant ions in water samples from sites 5 and 6 in the Weber River basin. Sulfate concentrations are particularly low at these sites relative to concentrations at other sites. Major-ion concentrations in water samples from site 5 did not vary much seasonally but were lowest during those periods when a large volume of streamflow was released from upstream reservoirs. The chemical composition and major-ion concentration in water samples from site 6 were very similar to those from site 5 during periods of snowmelt runoff. At site 6, upstream removal of water with low dissolved-solids concentration for irrigation and municipal supply use left inflows from urban and agricultural areas as primary streamflow components during base-flow conditions and caused water samples to be enriched with sodium and chloride.
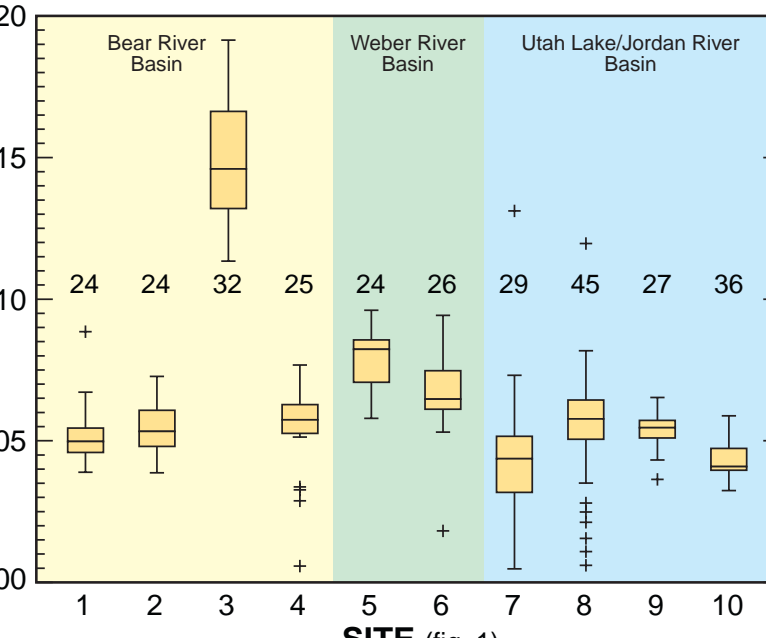

39 Number of samples

\section{EXPLANATION}

+ Data value greater than 1.5 times the IQR outside the box Largest data value within 1.5 times the IQR above the box 75 th percentile

Median (50th percentile) $\}$ Interquartile Range (IQR)

25th percentile

Smallest data value within 1.5 times the IQR below the box

+ Data value less than 1.5 times the IQR outside the box

Figure 20. Molar ratio of potassium to sodium in water samples from fixed sites in the Great Salt Lake Basins study unit. 
Samples from each of the four sites in the Utah Lake/Jordan River basin had markedly different majorion chemistry. The calcium bicarbonate type water in all samples from site 9 on Red Butte Creek, a forest/rangeland indicator site, is representative of that of most headwaters in this basin. Site 9 is in an undeveloped subbasin, and ground-water discharge and surface runoff of precipitation are the only streamflow components. Geochemical reactions among minerals in the aquifer material and in the ground water, which is discharged to the stream, largely determine the majorion composition of water at this site. Samples from sites 7 and 8, urban indicator sites on Little Cottonwood Creek, showed the largest range of majorion concentrations. Calcium and bicarbonate were the predominant ions in the May-June samples, whereas sodium and chloride were dominant during winter base-flow conditions. Dissolved-solids concentrations measured in samples collected during May-June were less than one-fourth of those measured in some samples collected during winter base-flow conditions. The winter base-flow samples had been enriched with sodium and chloride, probably from road salt (Gerner, 2003). Summer base flow at sites 7 and 8 consisted mostly of ground-water inflow and runoff from lawn irrigation. Differences in major-ion composition at these two sites during summer base-flow conditions may be a result of differences in source water. The ground-water component of streamflow at site 7 is mostly from a localized, shallow, perched aquifer, and the irrigation-return component generally is from residential systems that use water from the publicsupply system. Base flow at site 8 includes groundwater seepage from the shallow aquifer in the basin-fill deposits and irrigation return from residential systems that use water from the public-supply system and from canals that transport water from the Jordan River. The urban area associated with site 8 is much larger than that with site 7 , and most of the increase in major-ion concentrations between the two sites can be attributed to the influence of urban land cover.

Site 10 on the Jordan River generally had the highest concentration of major ions of all the sites. Winter base-flow samples were slightly enriched with sodium and chloride, probably as a result of road salt dissolved in surface runoff to the Jordan River and tributary streams. Less seasonal change in major-ion chemistry occurred at site 10 than at sites 7 and 8, mostly because Utah Lake is a consistent source of major ions for the Jordan River, but also because ground-water inflow and discharge from waste-water treatment facilities are fairly large and consistent components of flow at site 10 .

\section{Nutrients and Suspended Sediment}

Nutrients, including nitrogen and phosphorus, are essential to the health and function of natural ecosystems. Insufficient amounts of nutrients can lower growth rates of primary producers, such as aquatic vegetation, and limit the diversity and productivity of the ecosystem. Excessive nutrient loading can result in public health concerns and a general decline of the aquatic ecosystem health caused by accelerated growth of algae (U.S. Environmental Protection Agency, 1998). Nutrients occur naturally in streams as a result of mineral weathering and biological activity in the streambed sediment. Streams may receive additional nutrients from agricultural and urban runoff, atmospheric deposition, and waste-water discharge.

Nitrogen species analyzed for included ammonia, nitrite, nitrite plus nitrate, ammonia plus organic nitrogen, and total ammonia plus organic nitrogen (table 4). From these measured constituents, particulate organic nitrogen, dissolved organic nitrogen, dissolved nitrate, and total nitrogen can be calculated (table 5). Phosphorus species analyzed for at the fixed sites included total phosphorus, orthophosphate, and dissolved phosphorus.

The total-nitrogen concentration measured at sites $1,2,5$, and 9 generally was less than $1 \mathrm{mg} / \mathrm{L}$, as low as 0.06 at site 9 . The drainage basins above these sites are predominantly rangeland and forest land cover. Total-nitrogen concentration at sites 3 and 4, with more agricultural land use, ranged from 0.5 to 4.6 $\mathrm{mg} / \mathrm{L}$. Total-nitrogen concentration at sites $6,7,8$, and 10 , with larger amounts of urban land cover, ranged from 0.3 to $11 \mathrm{mg} / \mathrm{L}$. Nitrogen in outflow from wastewater treatment plants and urban runoff contributed to site 10 having the highest median total-nitrogen concentration (2.79 mg/L) among the sites (fig. 21). Agricultural runoff and outflow from waste-water treatment plants entering Cub River contributed to site 3 having the second highest median total-nitrogen concentration $(1.80 \mathrm{mg} / \mathrm{L})$ among fixed sites. 
Table 5. Nitrogen species analyzed for and calculated from water samples collected at fixed sites in the Great Salt Lake Basins study unit

[NWIS, National Water Information System; NA, not applicable]

\begin{tabular}{|c|c|c|c|c|}
\hline Nitrogen species & Derivation & $\begin{array}{l}\text { NWIS parameter } \\
\text { code }\end{array}$ & Algorithm for calculated species & Remark \\
\hline \multicolumn{5}{|l|}{ Total } \\
\hline Nitrogen & Calculated & 600 & $\begin{array}{l}\text { (Ammonia plus organic } \\
\text { nitrogen) plus (nitrite plus } \\
\text { nitrate) }\end{array}$ & $\begin{array}{l}\text { Total nitrogen is made up of dissolved } \\
\text { inorganic and organic nitrogen and } \\
\text { particulate organic and inorganic nitrogen, } \\
\text { with N2 gas subtracted. }\end{array}$ \\
\hline Ammonia plus organic & Measured & 625 & NA & Total Kjeldahl nitrogen. \\
\hline \multicolumn{5}{|l|}{ Particulate } \\
\hline Particulate organic & Calculated & None & $\begin{array}{l}\text { (Total ammonia plus organic } \\
\text { nitrogen) minus (dissolved } \\
\text { ammonia plus organic } \\
\text { nitrogen) }\end{array}$ & $\begin{array}{l}\text { Particulate organic nitrogen is composed of } \\
\text { detritus and other dead cell matter in } \\
\text { addition to phytoplankton and other living } \\
\text { protoplasm. }\end{array}$ \\
\hline \multicolumn{5}{|l|}{ Dissolved $^{1}$} \\
\hline Nitrogen & Calculated & 602 & $\begin{array}{l}\text { (Dissolved ammonia plus } \\
\text { organic nitrogen) plus } \\
\text { (nitrite plus nitrate) }\end{array}$ & \\
\hline Ammonia plus organic & Measured & 623 & $\mathrm{NA}$ & Filtered Kjeldahl nitrogen. \\
\hline Organic & Calculated & 607 & $\begin{array}{l}\text { (Dissolved ammonia plus } \\
\text { organic nitrogen) minus } \\
\text { (dissolved ammonia) }\end{array}$ & $\begin{array}{l}\text { Dissolved organic nitrogen consists of humic } \\
\text { and fulvic acids, macromolecules, organic } \\
\text { colloids, and other organic molecule } \\
\text { fragments. }\end{array}$ \\
\hline Ammonia & Measured & 608 & NA & $\begin{array}{l}\text { Ammonia is present in aquatic systems mainly } \\
\text { as the ion } \mathrm{NH}_{4}^{+} \text {in waters with } \mathrm{pH} \text { below } \\
\text { 9.2. It is rapidly taken up by phytoplankton } \\
\text { and other aquatic plants for growth. }\end{array}$ \\
\hline Nitrite & Measured & 613 & NA & $\begin{array}{l}\text { Nitrite, a serious pollutant in high } \\
\text { concentrations, is formed by the bacterial } \\
\text { reduction of nitrate to nitrite or the } \\
\text { incomplete oxidation of } \mathrm{NH}_{3} \text {. }\end{array}$ \\
\hline Nitrite plus nitrate & Measured & 631 & NA & \\
\hline Nitrate & Calculated & 618 & $\begin{array}{l}\text { (Nitrite plus nitrate) minus } \\
\text { (nitrite) }\end{array}$ & $\begin{array}{l}\text { Nitrate is formed by the oxidation of ammonia } \\
\text { and nitrite. }\end{array}$ \\
\hline
\end{tabular}

Seasonal changes in total-nitrogen concentration occurred at most sites. Total-nitrogen concentration increased at most sites during base-flow conditions when discharge was low, ground water or treated waste water was the primary streamflow component, and uptake by aquatic vegetation was reduced. Totalnitrogen concentration decreased at most fixed sites during periods of snowmelt runoff. Because of discharge from upstream reservoirs, less seasonal change in total-nitrogen concentration occurred at sites 2 and 5 than at other sites.

The median concentration of dissolved ammonia at GRSL sites ranged from less than $0.02 \mathrm{mg} / \mathrm{L}$ (at sites 1, 2, 5, 7, and 9) to $0.21 \mathrm{mg} / \mathrm{L}$ (site 6) (fig. 21). Ammonia concentrations generally were higher at sites
6 and 10, probably because of contributions from waste-water treatment plants. Elevated concentrations of ammonia were detected at sites 7 and 8 in samples that had storm runoff from urban areas.

The median nitrite plus nitrate concentration at the GRSL sites ranged from less than $0.05 \mathrm{mg} / \mathrm{L}$ (site 9) to $2.08 \mathrm{mg} / \mathrm{L}$ (site 10) (fig. 21). Nitrite plus nitrate concentrations were lowest at sites $1,2,5$, and 9 where the drainages mostly have rangeland and forest land cover. Nitrite plus nitrate concentrations were highest at sites with runoff from agricultural land (sites 3 and 4) and sites with more urban land cover (sites 6, 7, 8, and 10). 


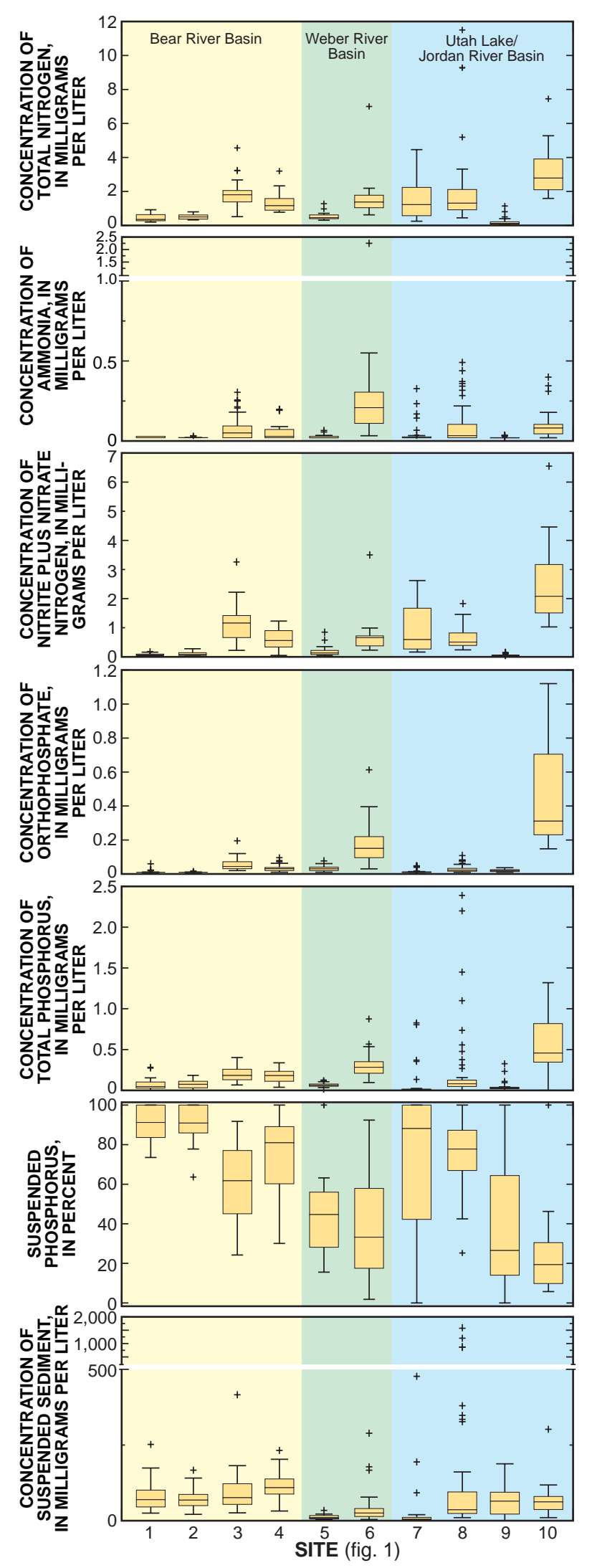

Figure 21. Concentration of suspended sediment, percentage of particulate phosphorus, and different forms of phosphorus and nitrogen in water samples from fixed sites in the Great Salt Lake Basins study unit.

\section{EXPLANATION}

+ Data value greater than 1.5 times the IQR outside the box

Targest data value within 1.5 times the IQR above the box

75th percentile

Median (50th percentile) Interquartile Range (IQR) 25th percentile

$\perp$ Smallest data value within 1.5 times the IQR below the box

+ Data value less than 1.5 times the IQR outside the box

The concentration of nitrogen species varies as the components of streamflow vary. Distribution of nitrogen species in a representative sample from each site (fig. 22) is shown during two base-flow periods (January and July 2000), low-altitude snowmelt runoff (March 2000), and high-altitude snowmelt runoff (May 2000). The overall height of the stacked bars in figure 22 is equal to total-nitrogen concentration in each sample.

Dissolved nitrate was the principal nitrogen component in water samples collected during January and March from GRSL sites. Dissolved ammonia and nitrite concentrations were elevated in water samples collected from many sites in January, possibly in part because of reduced uptake of nitrogen by aquatic vegetation. A retrospective analysis of nitrate data from the GRSL study unit by Thiros (2000) concluded that nitrate concentration was highest in water from wells associated with agricultural and urban land uses. A ground-water component may have contributed to the elevated nitrate concentrations in samples from sites 3 and 4 in the Bear River basin, site 6 on the Weber River, and sites 7, 8, and 10 in the Jordan River basin. Lower altitude snowmelt runoff was a major component of streamflow and a nutrient source at some sites during March 2000. Animal manure, either spread as fertilizer or resulting from livestock feeding operations and transported to streams in snowmelt runoff, may have been a substantial source of nitrate in samples collected during March.

Water samples from most GRSL sites had a much lower total-nitrogen concentration during May when higher altitude snowmelt was the major streamflow component. Dissolved and particulate organic nitrogen were the principal forms of nitrogen in water samples collected during May and generally made up a higher percentage of total nitrogen in samples relative to the percentage in samples collected during other periods. 

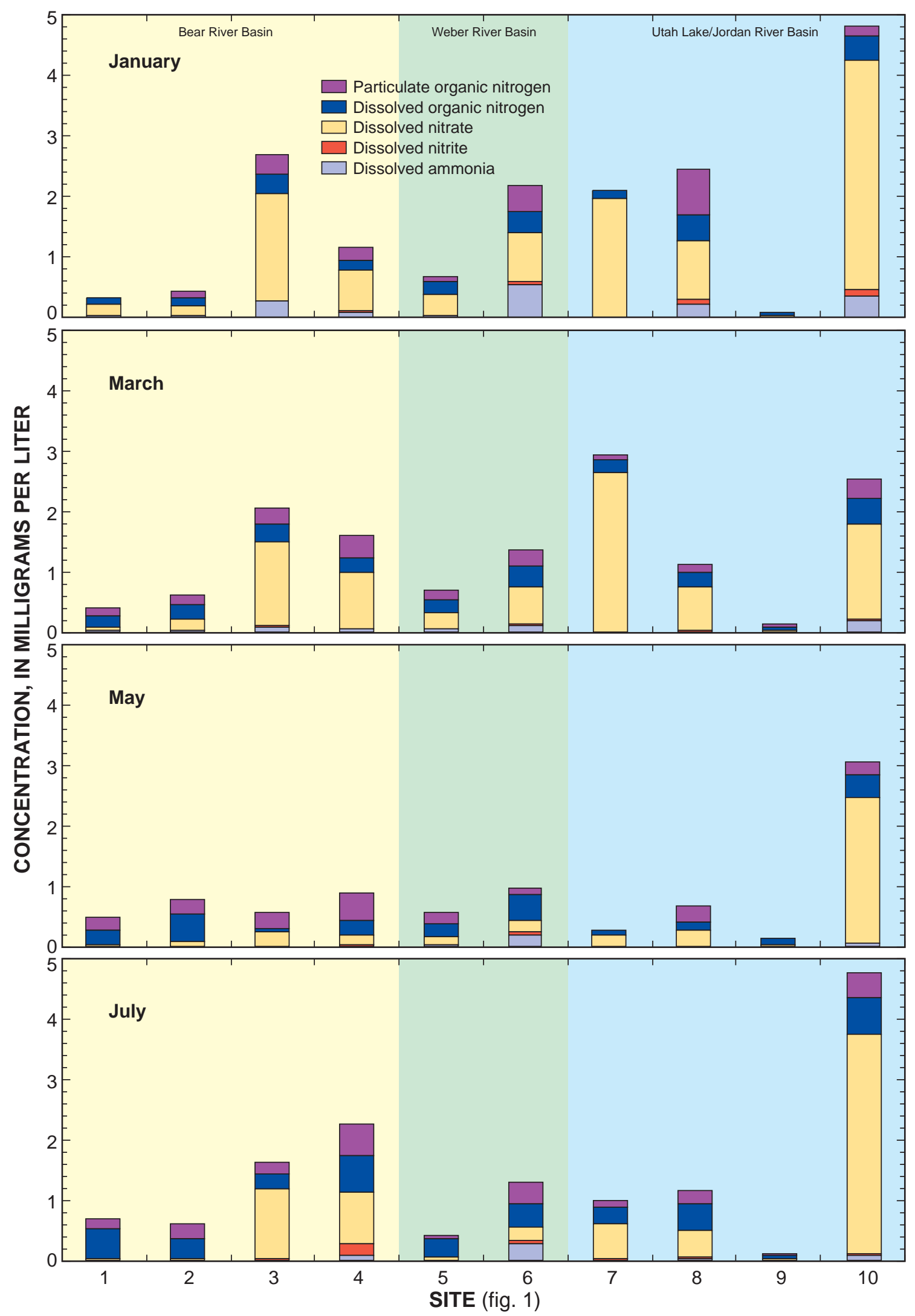

Figure 22. Concentration of dissolved and particulate nitrogen in water samples from fixed sites in the Great Salt Lake Basins study unit, January, March, May, and July 2000. 
During July, withdrawal of water (with a lower concentration of nutrients) from basin headwaters for irrigation resulted in lower streamflow and higher nitrogen concentration at some GRSL fixed sites. Streamflow components included ground-water discharge and irrigation return flow at most sites, and discharge from waste-water treatment plants at several sites. Organic nitrogen and nitrate were the principal forms of nitrogen in water samples collected during July.

The EPA has established AWQC for maximum ammonia concentrations in surface water (U.S. Environmental Protection Agency, 1999b). This criterion varies with $\mathrm{pH}$ and water temperature. Concentrations of dissolved ammonia in 95 percent of the samples from GRSL sites were less than $0.31 \mathrm{mg} / \mathrm{L}$. Within the ranges of $\mathrm{pH}$ (7.1 to 8.9) and water temperature $\left(0\right.$ to $\left.25^{\circ} \mathrm{C}\right)$ associated with samples from GRSL sites, ammonia concentrations did not exceed the chronic criterion. The maximum dissolved ammonia concentration was $2.25 \mathrm{mg} / \mathrm{L}$ (site 6). None of the samples from the GRSL sites had a nitrate concentration above the EPA drinking-water standard of $10 \mathrm{mg} / \mathrm{L}$. The maximum dissolved nitrate concentration at the sites was $6.54 \mathrm{mg} / \mathrm{L}$ (site 10). The Utah Department of Environmental Quality has designated a nitrate concentration of above $4.0 \mathrm{mg} / \mathrm{L}$ as an indicator of pollution. This level was exceeded three times at site 10, but was not exceeded at the other sites.

Orthophosphate concentrations were elevated at mixed-land-use sites 6 and 10 relative to at the other sites, probably as a result of a higher percentage of treated waste water in streamflow at these sites. Orthophosphate concentration in water samples from site 6 ranged from 0.03 to $0.61 \mathrm{mg} / \mathrm{L}$ with a median concentration of $0.15 \mathrm{mg} / \mathrm{L}$ (fig. 21). Orthophosphate concentration in water samples from site 10 ranged from 0.15 to $1.12 \mathrm{mg} / \mathrm{L}$ with a median concentration of $0.31 \mathrm{mg} / \mathrm{L}$. Orthophosphate concentrations were less than $0.21 \mathrm{mg} / \mathrm{L}$ in water samples from the other sites and the median concentration was less than $0.1 \mathrm{mg} / \mathrm{L}$.

Site 8 had the largest range in concentration of total phosphorus; from $0.029 \mathrm{mg} / \mathrm{L}$ during snowmelt runoff to $2.39 \mathrm{mg} / \mathrm{L}$ when storm runoff from the urban area was a large component of streamflow (fig. 21). Site 10, a mixed-land-use site heavily influenced by urban land uses, had a median total phosphorus concentration of $0.47 \mathrm{mg} / \mathrm{L}$, highest among the sites. Site 9 , a forest/rangeland site located in an undeveloped watershed, had a median total phosphorus concentration of $0.03 \mathrm{mg} / \mathrm{L}$, the lowest among the sites. According to Clark and others (2000), the median flow-weighted concentration of total phosphorus at 85 sites on streams in undeveloped areas of the United States was $0.022 \mathrm{mg} / \mathrm{L}$.

National criteria have not been established for the concentration of either dissolved or total phosphorus in streams. The EPA recommends that to prevent nuisance aquatic-plant growth, total phosphorus concentration should not exceed $0.10 \mathrm{mg} / \mathrm{L}$ in streams not discharging directly to lakes or impoundments (U.S. Environmental Protection Agency, 1986). Fifty percent of the samples collected at the sites exceeded a total phosphorus concentration of $0.10 \mathrm{mg} / \mathrm{L}$. The median total phosphorus concentration at sites $3,4,6$, and 10 exceeded 0.10 $\mathrm{mg} / \mathrm{L}$ (fig. 21), indicating that the potential for eutrophication exists. Sites 1, 2, 5, 7, 8, and 9 had a median concentration of total phosphorus ranging from $0.01 \mathrm{mg} / \mathrm{L}$ to $0.08 \mathrm{mg} / \mathrm{L}$.

The percentage of particulate phosphorus was highest in samples from sites in the Bear River basin (fig. 21). The phosphorus contained in water samples from urban mixed-land-use sites 6 and 10 generally was less than 50 percent particulate.

Total phosphorus concentration was well correlated with suspended sediment concentration in water samples from sites 1 (fig. 23), 7, and 8. When total phosphorus concentration in water samples was compared to suspended sediment the $\mathrm{R}^{2}$ for these sites ranged from 0.690 to 0.890 , with total phosphorus generally increasing with increased suspended sediment. Much of the phosphorus present in these samples was bound to sediment. The coefficient of determination for the relation between sediment and total phosphorus in samples collected from the rest of the sites ranged from 0.003 to 0.426 .

The highest concentrations of suspended sediment at GRSL sites were measured in water samples collected during a spring storm at site 8 , the urban indicator site on Little Cottonwood Creek. These samples contained concentrations of suspended sediment as high as $1,580 \mathrm{mg} / \mathrm{L}$ (fig. 21). The median concentration for all samples collected at this site was $36 \mathrm{mg} / \mathrm{L}$. Although the highest concentration occurred on Little Cottonwood Creek (Utah Lake/Jordan River basin), suspended-sediment concentrations generally were higher in the Bear River basin than in the Weber or Utah Lake/Jordan River drainage basins. Median concentrations of suspended sediment at sites in the 


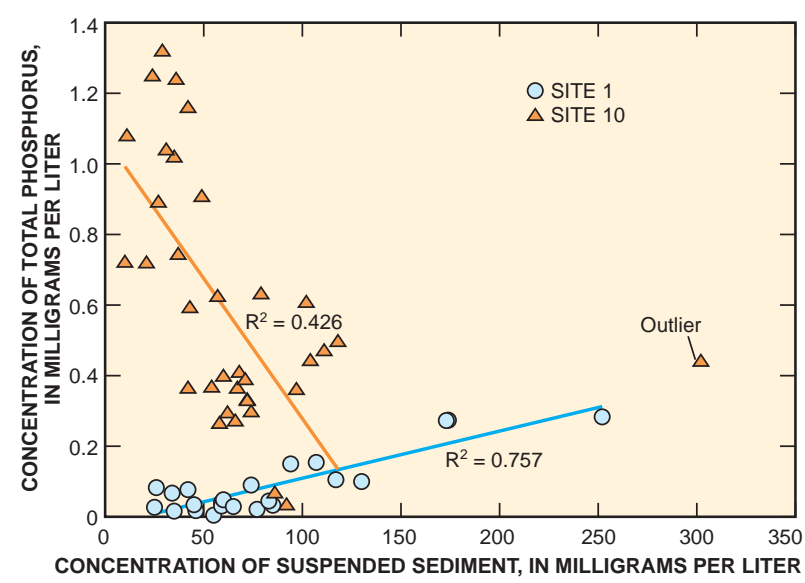

Figure 23. Concentration of total phosphorus in relation to suspended sediment in water samples from fixed sites 1 and 10 in the Great Salt Lake Basins study unit.

Bear River basin ranged from 68 to $110 \mathrm{mg} / \mathrm{L}$. Cutting of unstable stream banks during high or fluctuating streamflows, presence of livestock in riparian areas, and runoff from cropland during fallow periods are probably contributors to the higher sediment concentrations measured in samples from these sites.

The median concentration of suspended sediment in water samples collected from sites 5 and 6 on the Weber River and site 7 on Little Cottonwood Creek was the lowest among GRSL sites, less than 30 $\mathrm{mg} / \mathrm{L}$. Upstream from these sites, streambeds generally are made up of gravel, cobbles, and boulders; hence, banks are less prone to erosion. Rockport Reservoir captures much of the sediment in streamflow above site 5. Additionally, streamflow at site 7 often consists primarily of ground-water inflow that contributes little or no suspended sediment to the stream.

\section{Trace Elements}

Water samples analyzed for dissolved trace elements were collected at all sites to determine occurrence of these constituents and compare them with water-quality standards. Twenty or more samples were collected at sites 5, 7, 8, and 10 (table 3). One or two samples were collected from each of the remaining sites. Samples were analyzed for a suite of 22 trace elements (table 4).
Beryllium, cadmium, cobalt, and silver were not detected in any sample above the MRL of $1 \mu \mathrm{g} / \mathrm{L}$. Chromium was detected in 22 of 134 samples. The maximum concentration of chromium detected in samples from the sites was $9.9 \mu \mathrm{g} / \mathrm{L}$ at site 8 (fig. 24). Lead was detected in 5 of 134 samples and the maximum concentration, $1.58 \mu \mathrm{g} / \mathrm{L}$, occurred at site 5 . Nickel was detected in 90 of 134 samples and the maximum concentration, $8.6 \mu \mathrm{g} / \mathrm{L}$, occurred at site 10 . Concentrations of chromium, lead, and nickel did not exceed the AWQC guidelines. Boron, molybdenum, and strontium concentrations were enriched in samples from urban sites (8 and 10).

Arsenic was detected in 127 of 139 water samples. Concentrations were less than $15 \mu \mathrm{g} / \mathrm{L}$ at all sites except site 8 . Arsenic was detected in all 49 water samples from site 8 and the concentration ranged from 4.7 to $284 \mu \mathrm{g} / \mathrm{L}$. The AWQC for arsenic, $150 \mu \mathrm{g} / \mathrm{L}$, was exceeded in 8 of 49 samples at site 8 . Surface runoff and ground-water seepage near smelter tailings are the likely source of arsenic solutes in samples from site 8 (Gerner, 2003).

Copper was detected in 116 of 134 water samples from GRSL sites. Concentration ranged from $0.9 \mu \mathrm{g} / \mathrm{L}$ to $5.7 \mu \mathrm{g} / \mathrm{L}$. Copper concentration is generally too low and water hardness too high for copper in water samples from GRSL sites to exceed AWQC. Runoff from a spring rainstorm, however, lowered the hardness of the water in Little Cottonwood Creek and the AWQC for copper was exceeded twice in water samples collected from site 7 on Little Cottonwood Creek during that storm. Site 7 is located downstream from a historical mining district in an urban area, both of which may contribute to copper solutes in water samples from this site.

Selenium concentrations generally were low at all sites relative to the chronic AWQC, which is 4.6 $\mu \mathrm{g} / \mathrm{L}$ for dissolved selenium. Two samples from site 8 , Little Cottonwood Creek at Jordan River, exceeded the AWQC; the maximum concentration was $6.0 \mu \mathrm{g} / \mathrm{L}$.

Zinc concentration was highest in samples from sites 5, 7, and 8 . These three sites are downstream from historical mining districts and tailings are the most likely source of zinc to these streams. The maximum zinc concentration was $58 \mu \mathrm{g} / \mathrm{L}$ at site 7 . None of the samples from this study had zinc concentrations above the AWQC when the criterion was adjusted for hardness. 

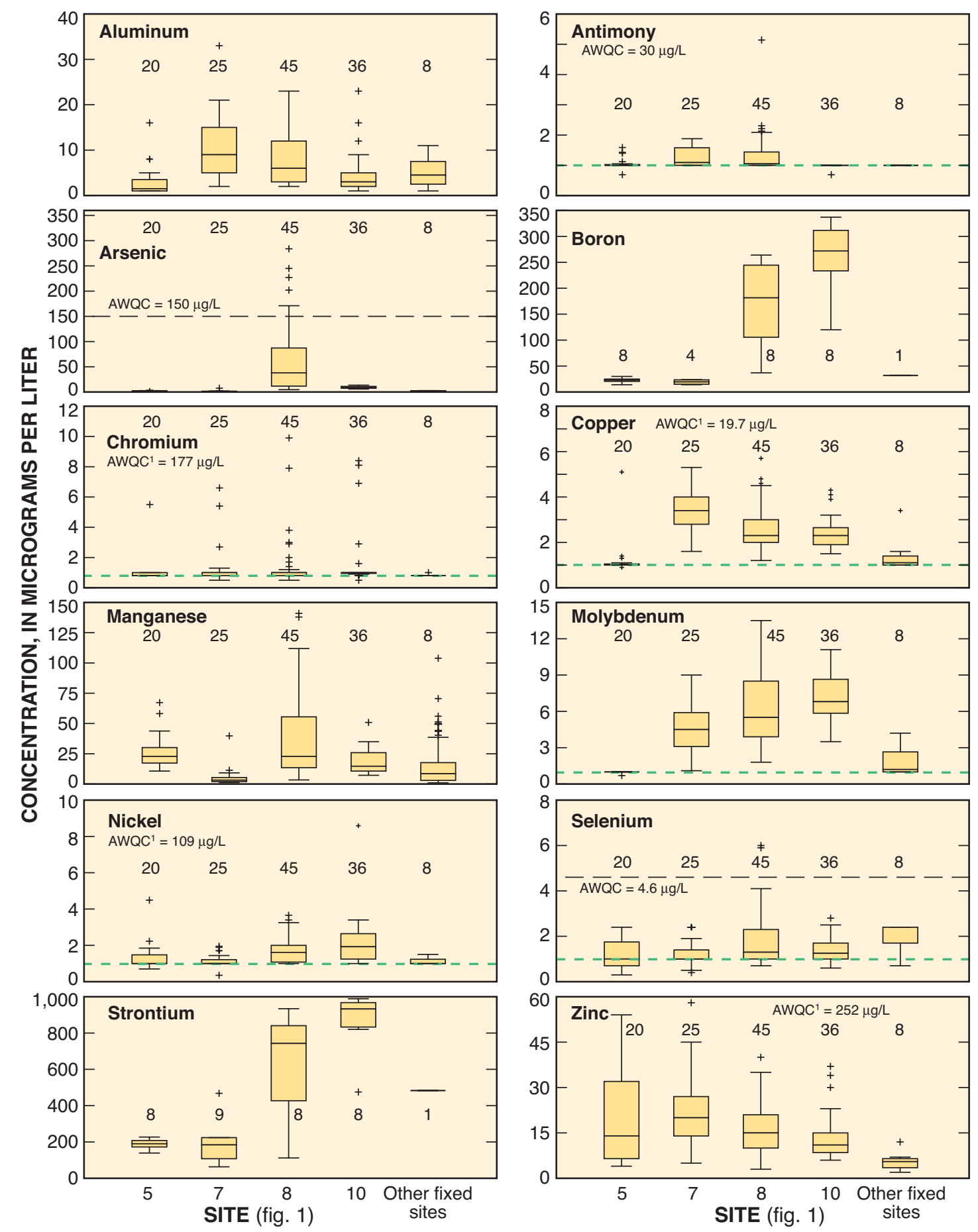

\section{EXPLANATION}

8 Number of samples

+ Data value greater than 1.5 times the IQR outside the box

Largest data value within 1.5 times the IQR above the box

75th percentile

Median (50th percentile) $\}$ Interquartile Range (IQR)

25th percentile

Smallest data value within 1.5 times the IQR below the box

+ Data value less than 1.5 times the IQR outside the box
- - - - Minimum reporting level

AWQC Ambient water-quality criteria for protection of aquatic wildlife, chronic exposure

AWQC $^{1}$ Ambient water-quality criteria-Adjusted for average hardness of fixed-site samples (240 milligrams per liter as $\left.\mathrm{CaCO}_{3}\right)$

$\mu \mathrm{g} / \mathrm{L} \quad$ Micrograms per liter

Figure 24. Concentration of selected trace elements in water samples from fixed sites in the Great Salt Lake Basins study unit. 


\section{Organic Compounds}

Uncertainty in the risks associated with contamination of surface water by pesticides and VOCs exists; however, their presence may affect the use of surface water for drinking water and recreation and for support of aquatic life. Water samples from some sites were analyzed for these organic compounds to determine their occurrence in the GRSL study unit (table 3).

Because organic carbon in aqueous systems is important for a number of chemical and biological processes, water samples from GRSL sites were analyzed for dissolved organic carbon. Dissolved organic carbon can affect the transport and degradation of pollutants and can participate in reactions that result in either the dissolution or formation of minerals.

\section{Pesticides}

Pesticides (herbicides and insecticides) are applied in many agricultural and nonagricultural settings in the GRSL study unit. They are used to control unwanted vegetation and destructive insects. Pesticides become environmental contaminants when they are transported from the site of application and enter the broader environment. They can reach surface water through direct application, surface runoff, atmospheric deposition, and ground-water inflow. Most pesticides are applied in agricultural and urban areas that generally drain into surface-water systems, making these systems particularly vulnerable to pesticide contamination. Pesticides in streams and rivers become widely dispersed as they move through surface-water systems (Larson and others, 1997).

Water samples collected from sites 3, 5, 7, 8, 9, and 10 were analyzed for pesticides (table 3 ). Sites 3, 8, and 10 were sampled more frequently for pesticides because their drainage basins were most likely to experience pesticide application for agricultural or urban use. Results from pesticide sampling reported here are from only these three sites. Samples collected for pesticide analysis targeted those periods and events most likely to result in pesticide detections. Detection frequencies are likely biased because periods with minimal pesticide application were sampled less often than periods during which pesticides were applied.

Water samples were analyzed for pesticides by using both gas chromatography/mass spectrometry (GC/MS) and high-performance liquid chromato- graphy/mass spectrometry (HPLC/MS) (table 3). Samples were analyzed for 107 pesticides; 48 of them by GC/MS and 59 by HPLC/MS (table 6 ). The HPLC/MS method was a new method that was being validated at the USGS National Water Quality Laboratory during this study; hence, data from these analyses remain provisional. Pesticides detected in water samples analyzed by HPLC/MS are listed in table 7; however, no summary statistics associated with concentration are reported here. Most of the samples analyzed by HPLC/MS were held beyond the normal limit of 4 days, which may have resulted in degradation of some compounds initially present in the water samples to a concentration below the method reporting level.

Forty-three different pesticides were detected in samples from sites 3, 8, and 10 (tables 7 and 8): 21 at the Cub River agricultural site (site 3), 32 at the Little Cottonwood Creek urban site (site 8), and 33 at the Jordan River mixed-land-use site (site 10). Thirty-one of the pesticides detected were herbicides, 4 were herbicide metabolites, 7 were insecticides, and 1 was a fungicide. Among the pesticides analyzed by GC/MS, the herbicides atrazine and prometon, and the insecticides carbaryl and diazinon, were the most frequently detected. The highest average number of pesticides detected per sample was at site 8 and the least at site 3 (table 9).

Atrazine is an herbicide that selectively controls broadleaf weeds without injury to the target crop. It is moderately persistent, with a half-life of about 60 days. Atrazine was the most frequently detected pesticide at site 3. It was detected in more than 90 percent of the samples analyzed by GC/MS from sites 3 and 10. The median atrazine concentration detected was $0.010 \mu \mathrm{g} / \mathrm{L}$ at sites 3 and 8 , and $0.012 \mu \mathrm{g} / \mathrm{L}$ at site 10 . The highest concentration of atrazine, $0.13 \mu \mathrm{g} / \mathrm{L}$, was detected at site 8 . Deethylatrazine and deethyldeisopropylatrazine, metabolites or transformation products of atrazine, were detected in water samples analyzed by HPLC/MS at all three sites. 
Table 6. Minimum reporting level of pesticides analyzed for in water samples collected at fixed sites in the Great Salt Lake Basins study unit

[MRL, minimum reporting level; $\mu \mathrm{g} / \mathrm{L}$, micrograms per liter; GC/MS, gas chromatography/ mass spectrometry; HPLC, high-performance liquid chromatography/mass spectrometry; H, herbicide; HM, herbicide metabolite; I, insecticide; IM, insecticide metabolite; F, fungicide]

\begin{tabular}{|c|c|c|}
\hline Pesticide & Type & $\begin{array}{c}\text { MRL } \\
(\mu \mathbf{g} / \mathbf{L})\end{array}$ \\
\hline \multicolumn{3}{|c|}{ Pesticides analyzed by GC/MS ${ }^{1}$} \\
\hline Acetochlor & $\mathrm{H}$ & 0.002 \\
\hline Alachlor & $\mathrm{H}$ & .002 \\
\hline Aniline, 2,6-diethyl & HM & .003 \\
\hline Atrazine & $\mathrm{H}$ & .001 \\
\hline Atrazine, Desethyl & HM & .002 \\
\hline Azinphos-methyl & I & .001 \\
\hline Benefin & $\mathrm{H}$ & .002 \\
\hline Butylate & $\mathrm{H}$ & .002 \\
\hline Carbaryl & I & .003 \\
\hline Carbofuran & I & .003 \\
\hline Chlorpyrifos & I & .004 \\
\hline Cyanazine & $\mathrm{H}$ & .004 \\
\hline Dacthal & $\mathrm{H}$ & .002 \\
\hline Deethylatrazine & HM & .006 \\
\hline$p, p^{\prime}-\mathrm{DDE}$ & $\mathrm{IM}$ & .006 \\
\hline Diazinon & I & .002 \\
\hline Dieldrin & I & .001 \\
\hline Disulfoton & I & .017 \\
\hline EPTC & $\mathrm{H}$ & .002 \\
\hline Ethalfluralin & $\mathrm{H}$ & .004 \\
\hline Ethoprop & I & .003 \\
\hline Ethyl Parathion & I & .004 \\
\hline Fonofos & I & .003 \\
\hline $\mathrm{HCH}$, -alpha & IM & .002 \\
\hline Lindane (Gamma-hch) & I & .004 \\
\hline Linuron & $\mathrm{H}$ & .002 \\
\hline Malathion & I & .005 \\
\hline Methyl Parathion & I & .006 \\
\hline Metolachlor & $\mathrm{H}$ & .002 \\
\hline Metribuzin & $\mathrm{H}$ & .004 \\
\hline Molinate & $\mathrm{H}$ & .004 \\
\hline Napropamide & $\mathrm{H}$ & .003 \\
\hline Pebulate & $\mathrm{H}$ & .004 \\
\hline Pendimethalin & $\mathrm{H}$ & .004 \\
\hline Permethrin & I & .005 \\
\hline Phorate & I & .002 \\
\hline Prometon & $\mathrm{H}$ & .018 \\
\hline Pronamide (Propyzamide) & $\mathrm{H}$ & .003 \\
\hline Propachlor & $\mathrm{H}$ & .007 \\
\hline Propanil & $\mathrm{H}$ & .004 \\
\hline Propargite & I & .013 \\
\hline Simazine & $\mathrm{H}$ & .005 \\
\hline Tebuthiuron & $\mathrm{H}$ & .01 \\
\hline Terbacil & $\mathrm{H}$ & .007 \\
\hline Terbufos & I & .013 \\
\hline Thiobencarb & $\mathrm{H}$ & .002 \\
\hline Triallate & $\mathrm{H}$ & .001 \\
\hline Trifluralin & $\mathrm{H}$ & .002 \\
\hline \multicolumn{3}{|c|}{ Pesticides analyzed by HPLC/MS² } \\
\hline 2,4-D & $\mathrm{H}$ & 0.0774 \\
\hline 2,4-D methyl ester & $\mathrm{H}$ & .0865 \\
\hline $2,4-\mathrm{DB}$ & $\mathrm{H}$ & ${ }^{3} .0538$ \\
\hline 2-Hydroxyatrazine & HM & 3.1927 \\
\hline 3(4-Chlorophenyl)-1-methyl urea & HM & .0915 \\
\hline 3-Hydroxycarbofuran & $\mathrm{IM}$ & .0623 \\
\hline 3-Ketocarbofuran & IM & ${ }^{3} .0723$ \\
\hline Acifluorfen & $\mathrm{H}$ & .0622 \\
\hline Aldicarb & I & ${ }^{3} .0815$ \\
\hline
\end{tabular}

\begin{tabular}{|c|c|c|}
\hline Pesticide & Type & $\begin{array}{c}\text { MRL } \\
(\mu \mathrm{g} / \mathrm{L})\end{array}$ \\
\hline \multicolumn{3}{|c|}{ Pesticides analyzed by HPLC/MS ${ }^{2}$-Continued } \\
\hline Aldicarb sulfone & IM & 3.1599 \\
\hline Aldicarb sulfoxide & IM & .0271 \\
\hline Bendiocarb & I & .0612 \\
\hline Benomyl & $\mathrm{F}$ & .0219 \\
\hline Bensulfuron-methyl & $\mathrm{H}$ & .0482 \\
\hline Bentazon & $\mathrm{H}$ & ${ }^{3} .0193$ \\
\hline Bromacil & $\mathrm{H}$ & ${ }^{3} .0807$ \\
\hline Bromoxynil & $\mathrm{H}$ & ${ }^{3} .0572$ \\
\hline Chloramben methyl ester & $\mathrm{H}$ & 3.1139 \\
\hline Chlorimuron-ethyl & $\mathrm{H}$ & .0367 \\
\hline Chlorothalonil & $\mathrm{H}$ & ${ }^{3} .0485$ \\
\hline Clopyralid & $\mathrm{H}$ & .0411 \\
\hline Cycloate & $\mathrm{H}$ & ${ }^{3} .0543$ \\
\hline Dacthal monoacid & HM & .0722 \\
\hline Deethyldeisopropylatrazine & HM & ${ }^{3} .0599$ \\
\hline Deisopropylatrazine & $\mathrm{HM}$ & ${ }^{3} .0737$ \\
\hline Dicamba & $\mathrm{H}$ & .096 \\
\hline Dichlorprop & $\mathrm{H}$ & .05 \\
\hline Dinoseb & $\mathrm{H}$ & .0429 \\
\hline Diphenamid & $\mathrm{H}$ & .0581 \\
\hline Diuron & $\mathrm{H}$ & .0793 \\
\hline Fenuron & $\mathrm{H}$ & .0735 \\
\hline Flumetsulam & $\mathrm{H}$ & ${ }^{3} .0866$ \\
\hline Fluometuron & $\mathrm{H}$ & .0617 \\
\hline Imazaquin & $\mathrm{H}$ & 3.103 \\
\hline Imazethapyr & $\mathrm{H}$ & ${ }^{3} .0879$ \\
\hline Imidacloprid & I & .106 \\
\hline Linuron & $\mathrm{H}$ & .0695 \\
\hline MCPA & $\mathrm{H}$ & .0585 \\
\hline MCPB & $\mathrm{H}$ & ${ }^{3} .0625$ \\
\hline Metalaxyl & $\mathrm{H}$ & .0571 \\
\hline Methiocarb & I & ${ }^{3} .0795$ \\
\hline Methomyl & I & ${ }^{3} .0768$ \\
\hline Methomyl oxime & IM & ${ }^{3} .0102$ \\
\hline Metsulfuron methyl & $\mathrm{H}$ & 3.1138 \\
\hline Neburon & $\mathrm{H}$ & .0747 \\
\hline Nicosulfuron & $\mathrm{H}$ & .0653 \\
\hline Norflurazon & $\mathrm{H}$ & ${ }^{3} .0774$ \\
\hline Oryzalin & $\mathrm{H}$ & .0711 \\
\hline Oxamyl & I & .016 \\
\hline Oxamyl oxime & IM & ${ }^{3} .0644$ \\
\hline Picloram & $\mathrm{H}$ & .0712 \\
\hline Propham & $\mathrm{H}$ & .0717 \\
\hline Propiconazole & $\mathrm{F}$ & .0643 \\
\hline Propoxur & $\mathrm{I}$ & .0594 \\
\hline Siduron & $\mathrm{H}$ & .0933 \\
\hline Sulfometuron-methyl & $\mathrm{H}$ & .0388 \\
\hline Terbacil & $\mathrm{H}$ & ${ }^{3} .0954$ \\
\hline Tribenuron-methyl & $\mathrm{H}$ & ${ }^{3} .0678$ \\
\hline Triclopyr & $\mathrm{H}$ & .1008 \\
\hline
\end{tabular}

${ }^{1}$ GC/MS, U.S. Geological Survey National Water Quality

Laboratory schedule 2001, 2010.

${ }^{2}$ HPLC/MS, U.S. Geological Survey National Water Quality Laboratory schedule LC9060.

3 Concentration is always reported as "estimated" because of variability of recovery. 
Table 7. Pesticides detected in water samples from three fixed sites by using high-performance liquid chromatography/mass spectrometry, Great Salt Lake Basins study unit

\begin{tabular}{ll}
\hline \multicolumn{1}{c}{ Site 3 (Cub River near Richmond) } \\
\hline 2,4 D & Dicamba \\
2,4 D Methyl ester & Diuron \\
2-Hydroxyatrazine & Picloram \\
Deethyldeisopropylatrazine & \\
\hline \multicolumn{1}{c}{ Site 8 (Little Cottonwood Creek at Jordan River) } \\
\hline 2,4 D & Deisopropylatrazine \\
2,4 DB & Dicamba \\
2,4 D Methyl ester & Diuron \\
2-Hydroxyatrazine & Flumetsulam \\
Benomyl & Imazaquin \\
Bromacil & MCPA \\
Deethyldeisopropylatrazine & Triclopyr \\
\hline \multicolumn{1}{c}{ Site 10 (Jordan River at Salt Lake City) } \\
\hline 2,4 D & Dichlopro \\
2,4 D Methyl ester & Dinoseb \\
2-Hydroxyatrazine & Diuron \\
Bromacil & MCPA \\
Deethyldeisopropylatrazine & Methomyl \\
Deisopropylatrazine & Metsulfuron methyl \\
Dicamba & Sulfometuron-methyl \\
& Triclopyr \\
\hline
\end{tabular}

Prometon was the most frequently detected pesticide at the urban and mixed-land-use sites. Prometon is a persistent, broad-spectrum herbicide, used for bare-ground weed control around buildings, along fences and roadways, and in other noncrop areas. It inhibits plant growth for 1 year or more. The physical and chemical properties of prometon indicate that it can become widely distributed throughout the environment (Capel and others, 1999), however, the toxicity of prometon to humans and aquatic organisms is largely unknown. Prometon was detected in more than 95 percent of the samples analyzed by GC/MS from sites 8 and 10 . The maximum prometon concentration was $5.61 \mu \mathrm{g} / \mathrm{L}$ at site 8 and $0.537 \mu \mathrm{g} / \mathrm{L}$ at site 10 . Prometon was detected at site 3 in 73 percent of the samples analyzed by GC/MS, but the maximum concentration did not exceed $0.030 \mu \mathrm{g} / \mathrm{L}$.

Carbaryl is a broad-spectrum carbamate insecticide that controls more than 100 species of insects. It is most often used in agricultural areas of Utah to control cereal leaf beetle and aphids on barley and wheat crops (Deer and Roe, 1997). Carbaryl was the most frequently detected insecticide at site 3 on the Cub River, having been detected in 38.5 percent of the samples analyzed by GC/MS. Carbaryl also was frequently detected at sites 8 and 10. It is used in urban areas to control insects, particularly caterpillars and beetles, on lawns, ornamental plants, vegetables, and fruit trees.

Diazinon is an organophosphate insecticide and is one of the most widely used insecticides in the United States, especially for household lawn and garden pest control. The highest concentration of diazinon detected in the GRSL study unit was 0.343 $\mu \mathrm{g} / \mathrm{L}$ at site 8 . Diazinon was the most frequently detected pesticide at site 8 and concentrations exceeded the aquatic-life criterion of $0.08 \mu \mathrm{g} / \mathrm{L}$ (International Joint Commission United States and Canada, 1989) in 8 of 42 water samples collected. Diazinon was detected in 46.9 percent of the samples from site 10 and in only one sample from site 3 . It did not exceed the aquaticlife criterion at either site.

Pesticides analyzed by GC/MS and detected above a common reporting limit of $0.05 \mu \mathrm{g} / \mathrm{L}$ are summarized in table 8 . Adjusting the MRL to 0.05 $\mu \mathrm{g} / \mathrm{L}$ censors detections less than $0.05 \mu \mathrm{g} / \mathrm{L}$ and results in a loss of detection information; however, with a common reporting limit a more uniform comparison of detection frequencies among constituents is possible. At a common reporting limit of $0.05 \mu \mathrm{g} / \mathrm{L}$, atrazine was the most frequently detected pesticide at site 3 , and prometon was the most frequently detected pesticide at sites 8 and 10. Carbaryl was the only pesticide detected above the common reporting limit in water samples from all three sites.

Pesticides detected by GC/MS in water samples from sites in the GRSL study unit were compared to those from 14 NAWQA study units (fig. 25) that measured pesticide concentration in surface-water samples during WY 1999-2000. These study units are referred to in this report as the national group. The number and frequency of pesticides detected at site 3 generally were much less than those detected in samples from agricultural sites in the national group (fig. 26). The pesticides carbaryl and diazinon, however, were detected at site 3 more often than they were detected at the national group agricultural sites. Carbaryl and prometon were detected more frequently at sites 8 and 10 than at the national group urban and mixed-land-use sites. Atrazine was detected much more frequently in samples aggregated from the national group than in samples from GRSL sites. This is reflective of the widespread use of atrazine on crops, especially corn, which cover large areas of many study units in the national group but do not cover much of the land area of the GRSL study unit. 
Table 8. Summary of pesticides detected in water samples from three fixed sites by using gas chromatography/mass spectrometry, Great Salt Lake Basins study unit

[ $\mu \mathrm{g} / \mathrm{L}$, microgram per liter; $\geq$, greater than or equal to; e, estimated; Type: H, herbicide; I, insecticide; HM, herbicide metabolite; AWQC, Ambient Water Quality Criteria for the protection of freshwater aquatic ecosystems; - , not established; concentrations in bold italics exceed AWQC]

\begin{tabular}{|c|c|c|c|c|c|c|c|c|c|}
\hline \multirow[b]{2}{*}{ Pesticide } & \multirow[b]{2}{*}{ Type } & \multirow[b]{2}{*}{$\begin{array}{l}\text { Number of } \\
\text { samples }\end{array}$} & \multicolumn{2}{|c|}{ Detections (percent) } & \multicolumn{3}{|c|}{ Concentration $(\mu \mathbf{g} / \mathbf{L})$} & \multirow[b]{2}{*}{$\begin{array}{l}\text { Human Health } \\
\text { Guideline }^{1}\end{array}$} & \multirow[b]{2}{*}{ AWOC } \\
\hline & & & $\begin{array}{l}\text { Method } \\
\text { reporting limit }\end{array}$ & $\begin{array}{c}\text { Common } \\
\text { reporting limit } \\
(\geq 0.05 \mu \mathrm{g} / \mathrm{L})\end{array}$ & Minimum & Median & Maximum & & \\
\hline \multicolumn{10}{|c|}{ Site 3 (Cub River near Richmond) } \\
\hline Atrazine & $\mathrm{H}$ & 26 & 92.3 & 7.7 & 0.004 & 0.010 & 0.075 & 3 & ${ }^{2} 1.8$ \\
\hline Carbaryl & I & 26 & 38.5 & 3.8 & $.003 \mathrm{e}$ & $.014 \mathrm{e}$ & $.174 \mathrm{e}$ & 700 & 2.2 \\
\hline Chlorpyrifos & I & 26 & 3.8 & .0 & $.003 \mathrm{e}$ & $.003 \mathrm{e}$ & $.003 \mathrm{e}$ & 20 & 3.041 \\
\hline Cyanazine & $\mathrm{H}$ & 26 & 11.5 & .0 & .008 & .010 & .036 & - & - \\
\hline Dacthal & $\mathrm{H}$ & 26 & 3.8 & .0 & $.002 \mathrm{e}$ & $.002 \mathrm{e}$ & $.002 \mathrm{e}$ & 70 & - \\
\hline Deethylatrazine & HM & 26 & 76.9 & .0 & $.003 \mathrm{e}$ & $.008 \mathrm{e}$ & $.033 \mathrm{e}$ & - & - \\
\hline Diazinon & I & 26 & 3.8 & 3.8 & .052 & .052 & .052 & 6 & ${ }^{4} .08$ \\
\hline EPTC & $\mathrm{H}$ & 26 & 7.7 & .0 & .008 & .010 & .013 & - & - \\
\hline Malathion & I & 26 & 3.8 & .0 & $.003 \mathrm{e}$ & $.003 \mathrm{e}$ & $.003 \mathrm{e}$ & 100 & 3.1 \\
\hline Metolachlor & $\mathrm{H}$ & 26 & 7.7 & .0 & .006 & .006 & .006 & 100 & 27.8 \\
\hline Prometon & $\mathrm{H}$ & 26 & 73.1 & .0 & .003 & .008 & .030 & 100 & - \\
\hline Tebuthiuron & $\mathrm{H}$ & 26 & 19.2 & .0 & $.005 \mathrm{e}$ & $.008 \mathrm{e}$ & $.019 \mathrm{e}$ & 500 & ${ }^{2} 1.6$ \\
\hline Triallate & $\mathrm{H}$ & 26 & 19.2 & .0 & $.002 \mathrm{e}$ & $.003 \mathrm{e}$ & $.016 \mathrm{e}$ & - & ${ }^{2} .24$ \\
\hline \multicolumn{10}{|c|}{ Site 8 (Little Cottonwood Creek at Jordan River) } \\
\hline Alachlor & $\mathrm{H}$ & 42 & 2.4 & .0 & .024 & .024 & .024 & 2 & \\
\hline Atrazine & $\mathrm{H}$ & 42 & 76.2 & 7.1 & .004 & .010 & .130 & 3 & 21.8 \\
\hline Benefin & $\mathrm{H}$ & 42 & 2.4 & .0 & $.002 \mathrm{e}$ & $.002 \mathrm{e}$ & $.002 \mathrm{e}$ & - & - \\
\hline Carbaryl & $\mathrm{I}$ & 42 & 66.7 & 23.8 & $.006 \mathrm{e}$ & $.021 \mathrm{e}$ & $.411 e$ & 700 & 2.2 \\
\hline Chlorpyrifos & I & 42 & 7.1 & .0 & .004 & $.005 \mathrm{e}$ & .007 & 20 & ${ }^{3} .041$ \\
\hline Dacthal & $\mathrm{H}$ & 42 & 45.2 & .0 & $.001 \mathrm{e}$ & $.004 \mathrm{e}$ & .027 & 70 & - \\
\hline Deethylatrazine & HM & 42 & 45.2 & .0 & $.003 \mathrm{e}$ & $.005 \mathrm{e}$ & $.022 \mathrm{e}$ & - & - \\
\hline Diazinon & I & 42 & 90.5 & 21.4 & $.003 \mathrm{e}$ & .024 & .343 & .6 & ${ }^{4} .08$ \\
\hline EPTC & $\mathrm{H}$ & 42 & 14.3 & .0 & $.001 \mathrm{e}$ & $.003 \mathrm{e}$ & .033 & - & - \\
\hline Fonofos & I & 42 & 2.4 & .0 & .015 & .015 & .015 & 10 & - \\
\hline Malathion & I & 42 & 33.3 & 4.8 & $.004 \mathrm{e}$ & .014 & .144 & 100 & 3.1 \\
\hline Metolachlor & $\mathrm{H}$ & 42 & 2.4 & .0 & $.004 \mathrm{e}$ & $.004 \mathrm{e}$ & $.004 \mathrm{e}$ & 100 & 27.8 \\
\hline Napropamide & $\mathrm{H}$ & 42 & 14.3 & .0 & $.008 \mathrm{e}$ & .038 & .048 & - & - \\
\hline Pendimethalin & $\mathrm{H}$ & 42 & 35.7 & 9.5 & .010 & .026 & .174 & - & - \\
\hline Prometon & $\mathrm{H}$ & 42 & 95.2 & 33.3 & $.005 \mathrm{e}$ & .034 & 5.61 & 100 & - \\
\hline Simazine & $\mathrm{H}$ & 42 & 21.4 & 2.4 & $.003 \mathrm{e}$ & $.005 \mathrm{e}$ & .419 & 4 & 210 \\
\hline Tebuthiuron & $\mathrm{H}$ & 42 & 35.7 & 2.4 & $.008 \mathrm{e}$ & $.017 \mathrm{e}$ & $.690 \mathrm{e}$ & 500 & 21.6 \\
\hline Trifluralin & $\mathrm{H}$ & 42 & 16.7 & .0 & $.001 \mathrm{e}$ & $.002 \mathrm{e}$ & $.004 \mathrm{e}$ & 5 & ${ }^{2} .2$ \\
\hline \multicolumn{10}{|c|}{ Site 10 (Jordan River at Salt Lake City) } \\
\hline Atrazine & $\mathrm{H}$ & 32 & 100.0 & .0 & .007 & .012 & .028 & 3 & ${ }^{2} 1.8$ \\
\hline Carbaryl & $\mathrm{I}$ & 32 & 43.8 & 12.5 & .009 & .022 & .093 & 700 & 2.2 \\
\hline Chlorpyrifos & I & 32 & 3.1 & .0 & .005 & .005 & .005 & 20 & ${ }^{3} .041$ \\
\hline Dacthal & $\mathrm{H}$ & 32 & 18.8 & .0 & $.001 \mathrm{e}$ & $.002 \mathrm{e}$ & .008 & 70 & - \\
\hline Deethylatrazine & HM & 32 & 84.4 & .0 & $.003 \mathrm{e}$ & $.007 \mathrm{e}$ & $.018 \mathrm{e}$ & - & - \\
\hline Diazinon & I & 32 & 46.9 & .0 & $.004 \mathrm{e}$ & .012 & .040 & .6 & 4.08 \\
\hline EPTC & $\mathrm{H}$ & 32 & 12.5 & 3.1 & .004 & .006 & .202 & - & - \\
\hline Ethalfluralin & $\mathrm{H}$ & 32 & 3.1 & .0 & .005 & .005 & .005 & - & - \\
\hline Lindane & I & 32 & 6.3 & .0 & $.004 \mathrm{e}$ & $.004 \mathrm{e}$ & $.004 \mathrm{e}$ & - & - \\
\hline Malathion & I & 32 & 37.5 & 3.1 & $.004 \mathrm{e}$ & .016 & .102 & 100 & ${ }^{3} .1$ \\
\hline Metolachlor & $\mathrm{H}$ & 32 & 9.4 & .0 & .004 & .006 & .007 & 100 & 27.8 \\
\hline Metribuzin & $\mathrm{H}$ & 32 & 3.1 & .0 & .011 & .011 & .011 & 200 & 21.0 \\
\hline Pendimethalin & $\mathrm{H}$ & 32 & 3.1 & 3.1 & .091 & .091 & .091 & - & - \\
\hline Prometon & $\mathrm{H}$ & 32 & 100.0 & 18.8 & $.004 \mathrm{e}$ & .026 & .537 & 100 & - \\
\hline Simazine & $\mathrm{H}$ & 32 & 37.5 & .0 & $.005 \mathrm{e}$ & .006 & .030 & 4 & 210 \\
\hline Tebuthiuron & $\mathrm{H}$ & 32 & 18.8 & .0 & .007 & .010 & .015 & 500 & 21.6 \\
\hline Triallate & $\mathrm{H}$ & 32 & 3.1 & 3.1 & .075 & .075 & .075 & - & 2.24 \\
\hline Trifluralin & $\mathrm{H}$ & 32 & 6.3 & .0 & $.003 \mathrm{e}$ & $.004 \mathrm{e}$ & $.004 \mathrm{e}$ & 5 & 2.2 \\
\hline
\end{tabular}


Table 9. Minimum, maximum, and average number of pesticides detected in water samples from three fixed sites, Great Salt Lake Basins study unit

[GC/MS, gas chromatography/mass spectrometry; HPLC/MS, high-performance liquid chromatography/mass spectrometry]

\begin{tabular}{|c|c|c|c|c|c|c|}
\hline \multirow{2}{*}{$\begin{array}{l}\text { Site number } \\
\text { (fig. 1) }\end{array}$} & \multirow{2}{*}{ Principal land use } & \multirow{2}{*}{$\begin{array}{c}\text { Analytical } \\
\text { method }\end{array}$} & \multirow{2}{*}{$\begin{array}{l}\text { Number of } \\
\text { samples }\end{array}$} & \multicolumn{3}{|c|}{ Number of detections per sample } \\
\hline & & & & Minimum & Maximum & Average \\
\hline \multirow[t]{2}{*}{3} & Agricultural & GC/MS & 26 & 2 & 10 & 5.6 \\
\hline & & HPLC/MS & 16 & 0 & 6 & 1.9 \\
\hline \multirow[t]{2}{*}{8} & Urban & GC/MS & 42 & 3 & 13 & 8.1 \\
\hline & & HPLC/MS & 24 & 0 & 8 & 3.0 \\
\hline \multirow[t]{2}{*}{10} & Mixed/urban & GC/MS & 33 & 4 & 13 & 7.3 \\
\hline & & HPLC/MS & 22 & 0 & 7 & 2.7 \\
\hline
\end{tabular}

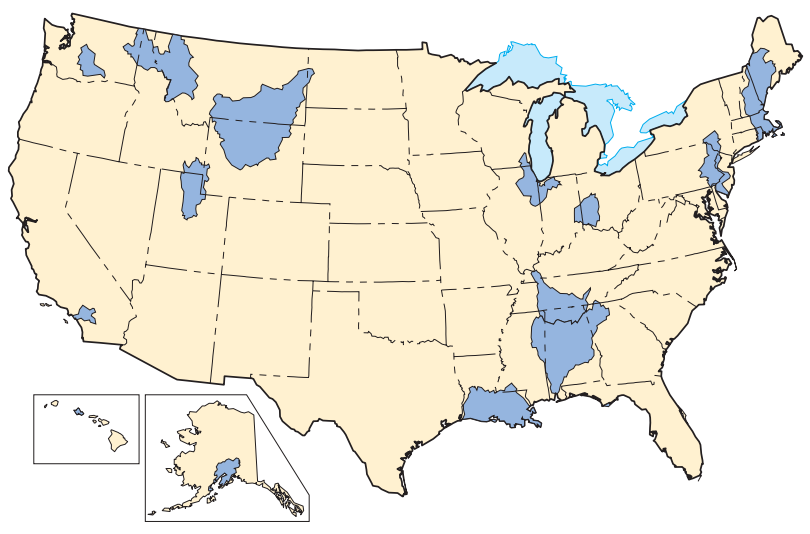

Figure 25. National Water-Quality Assessment program study units with pesticide and volatile organic compound concentration data, water years 1999-2000.

The 90th-percentile concentration of pesticides detected by GC/MS in water samples collected at agricultural, urban, and mixed-land-use sites in the GRSL study unit was compared to that in samples aggregated from sites in the national group with similar land use (fig. 27). The 90th-percentile concentration is that which exceeds 90 percent of the detected values and is used in this report to indicate the upper limit of normal values. In water samples from site 3 in the GRSL study unit, the 90th-percentile concentration of diazinon was slightly higher than in samples aggregated from agricultural sites in the national group of study units. The 90th-percentile concentration of all other pesticides detected in water samples from site 3 was much lower than in the samples from agricultural sites in the national group. The 90th-percentile concentration of carbaryl and diazinon was slightly higher, and prometon was much higher, in water samples from site 8 than in water samples from urban sites in the national group. At site 10, the 90thpercentile concentration of carbaryl and prometon was slightly higher, and triallate was much higher relative to mixed-land-use sites in the national group.

Eighteen of the 43 pesticides detected at GRSL sites have associated AWQC (table 8). At site 8, carbaryl concentrations exceeded the AWQC of 0.2 $\mu \mathrm{g} / \mathrm{L}$ four times and diazinon concentrations exceeded the AWQC of $0.08 \mu \mathrm{g} / \mathrm{L}$ eight times. Malathion concentrations exceeded the AWQC of $0.1 \mu \mathrm{g} / \mathrm{L}$ once at sites 8 and 10. Human health guidelines for drinking water have been established by the EPA for 22 of the 43 pesticides detected at GRSL sites. None of the pesticides detected exceeded EPA human health guidelines.

\section{Volatile Organic Compounds}

Samples collected at GRSL sites were analyzed for 86 VOCs, 35 of which were detected (table 10). VOCs are a class of compounds used in large quantities for numerous industrial, household, and agricultural purposes. They are present in fuels, exhaust, paint, adhesives, solvents, refrigerants, pesticides, and fumigants. Some likely pathways for VOCs to enter surface waters include (1) direct discharge into a stream from accidental spills and industrial or waste-water discharge, and (2) industrial and vehicle emissions, scavenged from air by precipitation, deposited directly into a stream, or transported in runoff. VOCs may enter a stream with highway runoff and urban stormwater and in ground water discharged to the stream.

Thirty-two samples for VOC analysis were collected at site 8 , and 26 were collected at site 10 (table 3). Sites 8 and 10 were chosen for intensive sampling for VOCs because of the high percentage of urban land use associated with them. Twenty-eight different VOCs were detected in samples from site 8 and 33 different VOCs were detected in samples from site 10 (table 11). All VOC samples collected at sites 8 and 10 had at least two VOCs detected. The number of VOCs detected per sample ranged from 2 to 19 at Little Cottonwood Creek 


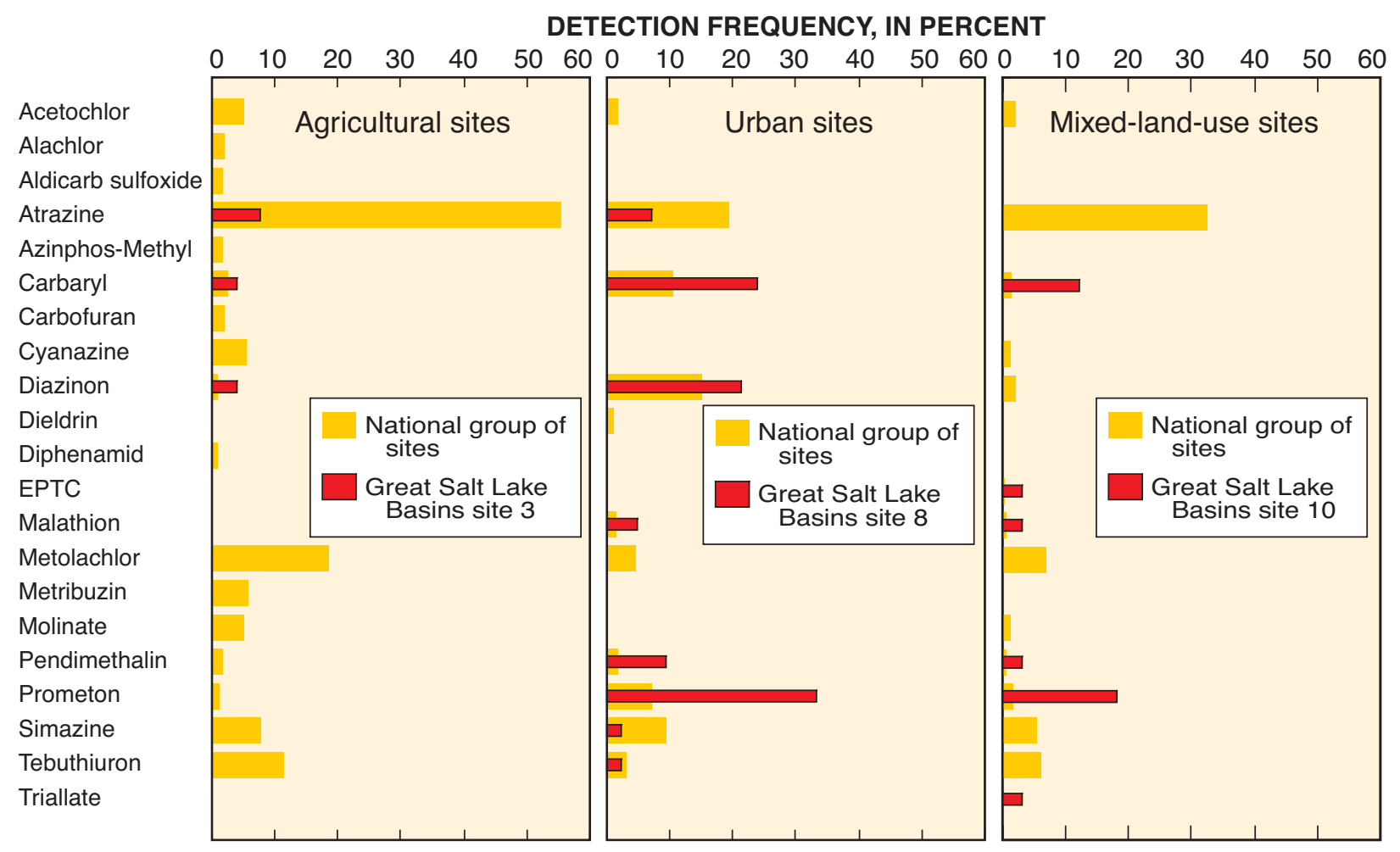

Figure 26. Detection frequency, based on a common reporting limit of 0.05 microgram per liter, of pesticides in water samples analyzed by gas chromatography/mass spectrometry from agricultural, urban, and mixed-land-use sites in the Great Salt Lake Basins study unit and at sites with similar land uses in study units across the Nation, water years 1999-2000.

(site 8) and 5 to 23 at Jordan River (site 10). The average number of VOCs detected per sample was 10.1 at site 8 and 12.1 at site 10 . Concentrations of most VOCs detected were low, less than $1 \mu \mathrm{g} / \mathrm{L}$. Concentrations of acetone, bromodichloromethane, chloroform, methylethylketone, methylisobutylketone, and toluene exceeded $1 \mu \mathrm{g} / \mathrm{L}$ in some samples.

Acetone was the VOC with the highest concentration, a maximum of $20 \mu \mathrm{g} / \mathrm{L}$ at site 8 and 4.47 $\mu \mathrm{g} / \mathrm{L}$ at site 10 . Chloroform and toluene were detected in more than 90 percent of the samples from sites 8 and 10 and were the most frequently detected VOCs. Four of the VOCs detected in samples from the GRSL sites (bromoform, bromodichloromethane, chloroform, and chlorodibromomethane) commonly are referred to as trihalomethanes (THMs). These compounds are formed when chlorine, used to treat drinking water, reacts with naturally occurring organic materials. THMs were detected much more frequently at site 10 than at site 8 , probably because treated waste water was a larger component of streamflow at site 10. Fuel- related BTEX compounds (benzene, toluene, ethylbenzene, and the xylenes) were frequently detected in samples from sites 8 and 10. Other VOCs detected in samples were solvents and those used in organic synthesis, fumigation, and plastics manufacturing.

One water sample collected at site 9 was analyzed to evaluate VOC occurrence in an undeveloped basin. Toluene was detected at a concentration of $0.02 \mathrm{e}$ (estimated) $\mu \mathrm{g} / \mathrm{L}$. No other VOCs were detected. Two water samples collected at site 7 were analyzed for VOCs, and benzene $(0.01 \mathrm{e} \mu \mathrm{g} / \mathrm{L})$ and chloroform $(0.01 \mathrm{e}$ and $0.05 \mathrm{e} \mu \mathrm{g} / \mathrm{L})$ were detected.

A comparison was made between VOCs detected in water samples from urban and mixed-land-use sites in the GRSL study unit with those detected in water samples from similar sites in a national group of NAWQA study units (fig. 25). A common reporting limit of $0.2 \mu \mathrm{g} / \mathrm{L}$ was used to censor data. EightVOCs at site 8 and 10 VOCs at site 10 were detected at or above the common reporting limit. Twice as many 


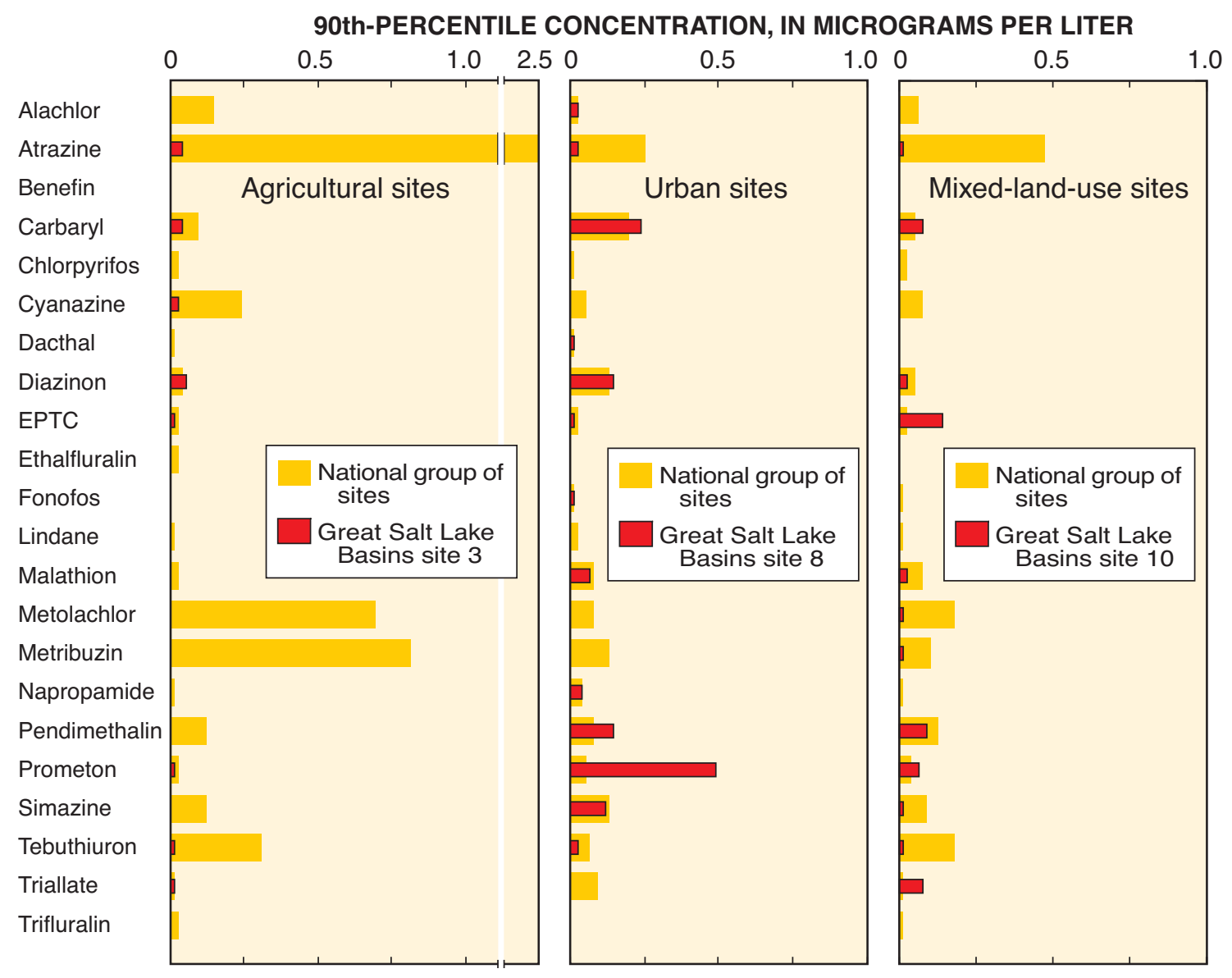

Figure 27. Ninetieth-percentile concentration of pesticides detected in water samples analyzed by gas chromatography/mass spectrometry from agricultural, urban, and mixed-land-use sites in the Great Salt Lake Basins study unit and sites with similar land uses in study units across the Nation, water years $1999-2000$

VOCs were detected in samples from similar sites in the national group of study units (fig. 28). The frequency of VOC detections in samples from GRSL sites 8 and 10 , however, generally was higher than in samples from the national group. At the common reporting limit, three THMs (bromodichloromethane, chloroform, and chlorodibromomethane) were detected at site 10 but none were detected at site 8 . These THMs were detected at site 10 in much higher frequencies and concentrations than in mixed land-use sites from the national group of study units (fig. 28). Toluene was detected above the common reporting limit in more than 20 percent of the samples from both site 8 and 10 , but in less than 10 percent of an aggregation of samples from urban and mixed-land-use sites in the national group. Other BTEX compounds, including xylenes and benzene, were detected at a higher frequency at site 8 than in samples from urban sites in the national group of study units. The solvents acetone, methylethylketone, and methylisobutylketone also were detected much more frequently at site 8 .

The 90th-percentile concentration of VOCs detected in water samples collected at GRSL sites was compared to that of samples from the national group of study units shown in figure 25 . As with pesticides, the 90th-percentile concentration is used to indicate the upper limit of normal values. The 90th-percentile concentration of three THMs (bromodichloromethane, chlorodibromomethane, and chloroform) in water samples from site 10 was much higher than that in water samples from mixed-land-use sites in the national group of study units (fig. 29). BTEX compounds toluene, xylene, and 1,2,4trimethylbenzene, and the solvents methylethylketone 
Table 10. Minimum reporting level of volatile organic compounds analyzed for in water samples collected at fixed sites in the Great Salt Lake Basins study unit

[CAS number, Chemical Abstract Service number; MRL, minimum reporting level; $\mu \mathrm{g} / \mathrm{L}$, micrograms per liter]

\begin{tabular}{|c|c|c|c|c|}
\hline Compound code name & $\begin{array}{l}\text { Compound } \\
\text { code }\end{array}$ & $\begin{array}{l}\text { Preferred compound } \\
\text { name }\end{array}$ & $\begin{array}{c}\text { CAS } \\
\text { number }\end{array}$ & $\underset{(\mu \mathrm{g} / \mathrm{L})}{\mathrm{MRL}}$ \\
\hline DIISOPROPYL ETHER & 81577 & Diisopropyl ether & $108-20-3$ & 0.098 \\
\hline 1,1,1-TRICHLOROETHANE & 34506 & 1,1,1-Trichloroethane & $71-55-6$ & .032 \\
\hline 1,1,2-TRICHLOROETHANE & 34511 & 1,1,2-Trichloroethane & $79-00-5$ & .064 \\
\hline 1,1-DICHLOROETHANE & 34496 & 1,1-Dichloroethane & $75-34-3$ & .066 \\
\hline 1,1-DICHLOROETHYLENE & 34501 & 1,1-Dichloroethene & $75-35-4$ & .044 \\
\hline 1,1-DICHLOROPROPENE & 77168 & 1,1-Dichloropropene & $563-58-6$ & .026 \\
\hline 1,2,3-TRICHLOROPROPANE & 77443 & 1,2,3-Trichloropropane & $96-18-4$ & .16 \\
\hline 1,2-DIBROMOETHANE & 77651 & 1,2-Dibromoethane & $106-93-4$ & .036 \\
\hline 1,2-DICHLOROETHANE & 32103 & 1,2-Dichloroethane & $107-06-2$ & .13 \\
\hline 1,2-DICHLOROPROPANE & 34541 & 1,2-Dichloropropane & $78-87-5$ & .068 \\
\hline 1,2-TRANSDICHLOROETHENE & 34546 & trans-1,2-Dichloroethene & $156-60-5$ & .032 \\
\hline 2,2-DICHLOROPROPANE & 77170 & 2,2-Dichloropropane & $594-20-7$ & .078 \\
\hline 2-BUTENE, TRANS-1,4-DICHLORO- & 73547 & trans-1,4-Dichloro-2-butene & $110-57-6$ & .7 \\
\hline 2-HEXANONE & 77103 & 2-Hexanone & $591-78-6$ & .7 \\
\hline ACETONE & 81552 & Acetone & $67-64-1$ & 5 \\
\hline ACRYLONITRILE & 34215 & 2-Propenenitrile & $107-13-1$ & 1.2 \\
\hline BENZENE & 34030 & Benzene & $71-43-2$ & .1 \\
\hline BENZENE, 1,2,3-TRICHLORO- & 77613 & 1,2,3-Trichlorobenzene & $87-61-6$ & .27 \\
\hline BENZENE, 1,2,3-TRIMETHYL- & 77221 & 1,2,3-Trimethylbenzene & $526-73-8$ & .12 \\
\hline BENZENE, 1,2,4-TRICHLORO- & 34551 & 1,2,4-Trichlorobenzene & $120-82-1$ & .19 \\
\hline BENZENE, 1,2,4-TRIMETHYL- & 77222 & 1,2,4-Trimethylbenzene & $95-63-6$ & .056 \\
\hline BENZENE, 1,3,5-TRIMETHYL- & 77226 & 1,3,5-Trimethylbenzene & $108-67-8$ & .044 \\
\hline BENZENE, 1,3-DICHLORO- & 34566 & 1,3-Dichlorobenzene & $541-73-1$ & .054 \\
\hline BENZENE, 1,4-DICHLORO- & 34571 & 1,4-Dichlorobenzene & $106-46-7$ & .05 \\
\hline BENZENE, ISOPROPYL- & 77223 & (1-Methylethyl)benzene & $98-82-8$ & .032 \\
\hline BENZENE, N-BUTYL- & 77342 & n-Butylbenzene & $104-51-8$ & .19 \\
\hline BENZENE, N-PROPYL- & 77224 & n-Propylbenzene & $103-65-1$ & .042 \\
\hline BENZENE, O-DICHLORO- & 34536 & 1,2-Dichlorobenzene & $95-50-1$ & .048 \\
\hline BENZENE, SEC-BUTYL- & 77350 & (1-Methylpropyl)benzene & $135-98-8$ & .048 \\
\hline BENZENE, TERT-BUTYL- & 77353 & (1,1-Dimethylethyl)benzene & $98-06-6$ & .1 \\
\hline BROMOBENZENE & 81555 & Bromobenzene & $108-86-1$ & .036 \\
\hline BROMOETHENE & 50002 & Bromoethene & $593-60-2$ & .1 \\
\hline BROMOFORM & 32104 & Tribromomethane & $75-25-2$ & .1 \\
\hline CARBON DISULFIDE & 77041 & Carbon disulfide & $75-15-0$ & .37 \\
\hline CARBONTETRACHLORIDE & 32102 & Tetrachloromethane & $56-23-5$ & .088 \\
\hline CHLOROBENZENE & 34301 & Chlorobenzene & $108-90-7$ & .028 \\
\hline CHLORODIBROMOMETHANE & 32105 & Dibromochloromethane & $124-48-1$ & .18 \\
\hline CHLOROETHANE & 34311 & Chloroethane & $75-00-3$ & .12 \\
\hline CHLOROFORM & 32106 & Trichloromethane & $67-66-3$ & .052 \\
\hline CIS-1,2-DICHLOROETHENE & 77093 & cis-1,2-Dichloroethene & $156-59-2$ & .038 \\
\hline CIS-1,3-DICHLOROPROPENE & 34704 & cis-1,3-Dichloropropene & $10061-01-5$ & .09 \\
\hline DIBROMOCHLOROPROPANE & 82625 & 1,2-Dibromo-3-chloropropane & $96-12-8$ & .21 \\
\hline DIBROMOMETHANE & 30217 & Dibromomethane & $74-95-3$ & .05 \\
\hline DICHLOROBROMOMETHANE & 32101 & Bromodichloromethane & $75-27-4$ & .048 \\
\hline DICHLORODIFLUOROMETHANE & 34668 & Dichlorodifluoromethane & $75-71-8$ & .14 \\
\hline ETHANE, 1,1,1,2-TETRACHLORO- & 77562 & $1,1,1,2$-Tetrachloroethane & $630-20-6$ & .044 \\
\hline ETHANE, $1,1,2,2$-TETRACHLORO- & 34516 & 1,1,2,2-Tetrachloroethane & $79-34-5$ & .13 \\
\hline ETHANE, HEXACHLORO- & 34396 & $1,1,1,2,2,2$-Hexachloroethane & $67-72-1$ & .36 \\
\hline ETHER, ETHYL- & 81576 & Diethyl ether & $60-29-7$ & .17 \\
\hline ETHER, TERT-BUTYL ETHYL- & 50004 & Ethyl tert-butyl ether & $637-92-3$ & .054 \\
\hline ETHER, TERT-PENTYL METHYL- & 50005 & tert-Amyl methyl ether & $994-05-8$ & .11 \\
\hline ETHYLBENZENE & 34371 & Ethylbenzene & $100-41-4$ & .03 \\
\hline FREON 113 & 77652 & 1,1,2-Trichloro-1,2,2-trifluoroethane & 76-13-1 & .032 \\
\hline FURAN, TETRAHYDRO- & 81607 & Tetrahydrofuran & $109-99-9$ & 9 \\
\hline HEXACHLOROBUTADIENE & 39702 & Hexachlorobutadiene & $87-68-3$ & .14 \\
\hline ISODURENE & 50000 & 1,2,3,5-Tetramethylbenzene & $527-53-7$ & .2 \\
\hline METHACRYLATE METHYL & 81597 & Methyl methacrylate & $80-26-6$ & .35 \\
\hline METHACRYLATE, ETHYL- & 73570 & Ethyl methacrylate & $97-63-2$ & .28 \\
\hline METHACRYLONITRILE & 81593 & Methyl acrylonitrile & $126-98-7$ & .57 \\
\hline METHANE, BROMOCHLORO- & 77297 & Bromochloromethane & $74-97-5$ & .044 \\
\hline METHYL ACRYLATE & 49991 & Methyl acrylate & $96-33-3$ & 1.4 \\
\hline
\end{tabular}


Table 10. Minimum reporting level of volatile organic compounds analyzed for in water samples collected at fixed sites in the Great Salt Lake Basins study unit-Continued

\begin{tabular}{|c|c|c|c|c|}
\hline Compound code name & $\begin{array}{l}\text { Compound } \\
\text { code }\end{array}$ & $\begin{array}{l}\text { Preferred compound } \\
\text { name }\end{array}$ & $\begin{array}{c}\text { CAS } \\
\text { number }\end{array}$ & $\begin{array}{l}\text { MRL } \\
(\mu \mathrm{g} / \mathbf{L})\end{array}$ \\
\hline METHYL IODIDE & 77424 & Iodomethane & $74-88-4$ & .21 \\
\hline METHYL TERTIARY-BUTYL ETHER (MTBE) & 78032 & Methyl tert-butyl ether & $1634-04-4$ & .17 \\
\hline METHYLBROMIDE & 34413 & Bromomethane & $74-83-9$ & .15 \\
\hline METHYLCHLORIDE & 34418 & Chloromethane & $74-87-3$ & .25 \\
\hline METHYLENECHLORIDE & 34423 & Dichloromethane & $75-09-2$ & .38 \\
\hline METHYLETHYLKETONE & 81595 & 2-Butanone & $78-93-3$ & 1.6 \\
\hline METHYLISOBUTYLKETONE & 78133 & 4-Methyl-2-pentanone & $108-10-1$ & .37 \\
\hline M-XYLENE/P-XYLENE & 85795 & 1,3\& 1,4-Dimethylbenzene & $106-42-3: 108-38-3$ & .06 \\
\hline NAPHTHALENE & 34696 & Naphthalene & $91-20-3$ & .25 \\
\hline O-CHLOROTOLUENE & 77275 & 1-Chloro-2-methylbenzene & $95-49-8$ & .042 \\
\hline O-XYLENE & 77135 & 1,2-Dimethylbenzene & $95-47-6$ & .06 \\
\hline P-ISOPROPYLTOLUENE & 77356 & 1-Isopropyl-4-methylbenzene & $99-87-6$ & .11 \\
\hline PREHNITENE & 49999 & 1,2,3,4-Tetramethylbenzene & $488-23-3$ & .23 \\
\hline PROPANE, 1,3-DICHLORO- & 77173 & 1,3-Dichloropropane & $142-28-9$ & .12 \\
\hline PROPENE, 3-CHLORO- & 78109 & 3-Chloro-1-propene & $107-05-1$ & .2 \\
\hline STYRENE & 77128 & Ethenylbenzene & $100-42-5$ & .042 \\
\hline TETRACHLOROETHYLENE & 34475 & Tetrachloroethene & $127-18-4$ & .1 \\
\hline TOLUENE & 34010 & Methylbenzene & $108-88-3$ & .05 \\
\hline TOLUENE, O-ETHYL- & 77220 & 2-Ethyltoluene & $611-14-3$ & .1 \\
\hline TOLUENE, P-CHLORO- & 77277 & 1-Chloro-4-methylbenzene & $106-43-4$ & .056 \\
\hline TRANS-1,3-DICHLOROPROPENE & 34699 & trans-1,3-Dichloropropene & $10061-02-6$ & .13 \\
\hline TRICHLOROETHYLENE & 39180 & Trichloroethene & $79-01-6$ & .038 \\
\hline TRICHLOROFLUOROMETHANE & 34488 & Trichlorofluoromethane & $75-69-4$ & .09 \\
\hline VINYLCHLORIDE & 39175 & Chloroethene & $75-01-4$ & .11 \\
\hline 1,3, and 1,4-DIMETHYLBENZENE & 85795 & m/p-Xylene (Dimethyl benzene) & $108-38-3$ & .06 \\
\hline
\end{tabular}

and methylisobutylketone had higher 90th-percentile concentrations in water samples from site 8 than in samples from the urban land-use sites in the national group of study units.

Methyl tert-butyl ether (MTBE), in particular, stands out as a VOC that was detected in higher concentrations and at much higher frequency in the national group than in samples from either site 8 or 10 (fig. 28 and 29). MTBE is a fuel oxygenate added to gasoline to increase octane levels and reduce emissions. Although oxygenated fuels are mandated in parts of the Utah Lake/Jordan River basin to control carbon monoxide emissions, the fuel oxygenate used is ethanol. This may explain why MTBE concentrations are lower in the study unit than in the national group. Possible sources of MTBE in the GRSL study unit include atmospheric washout and runoff from road surfaces contaminated by spills or emissions from vehicles fueled in out-of-state areas requiring MTBE or fueled in Utah with gasoline having MTBE added as an octane booster.
AWQC for the protection of aquatic organisms have been established for 15 of the 33 VOCs detected at GRSL sites. Toluene was the only VOC that exceeded the AWQC. Toluene exceeded the AWQC of $2 \mu \mathrm{g} / \mathrm{L}$ established by the Canadian Government (Canadian Council of Ministers of the Environment, 2001) in one sample from site 8 and very nearly exceeded it in a second sample from site 8 . These two samples, with concentrations of $3.15 \mu \mathrm{g} / \mathrm{L}$ and 1.99 $\mu \mathrm{g} / \mathrm{L}$, contained stormwater runoff from predominantly urban land cover. EPA human health guidelines have been established for 18 of the 33 VOCs detected at GRSL sites. None of the detections exceeded these guidelines. 


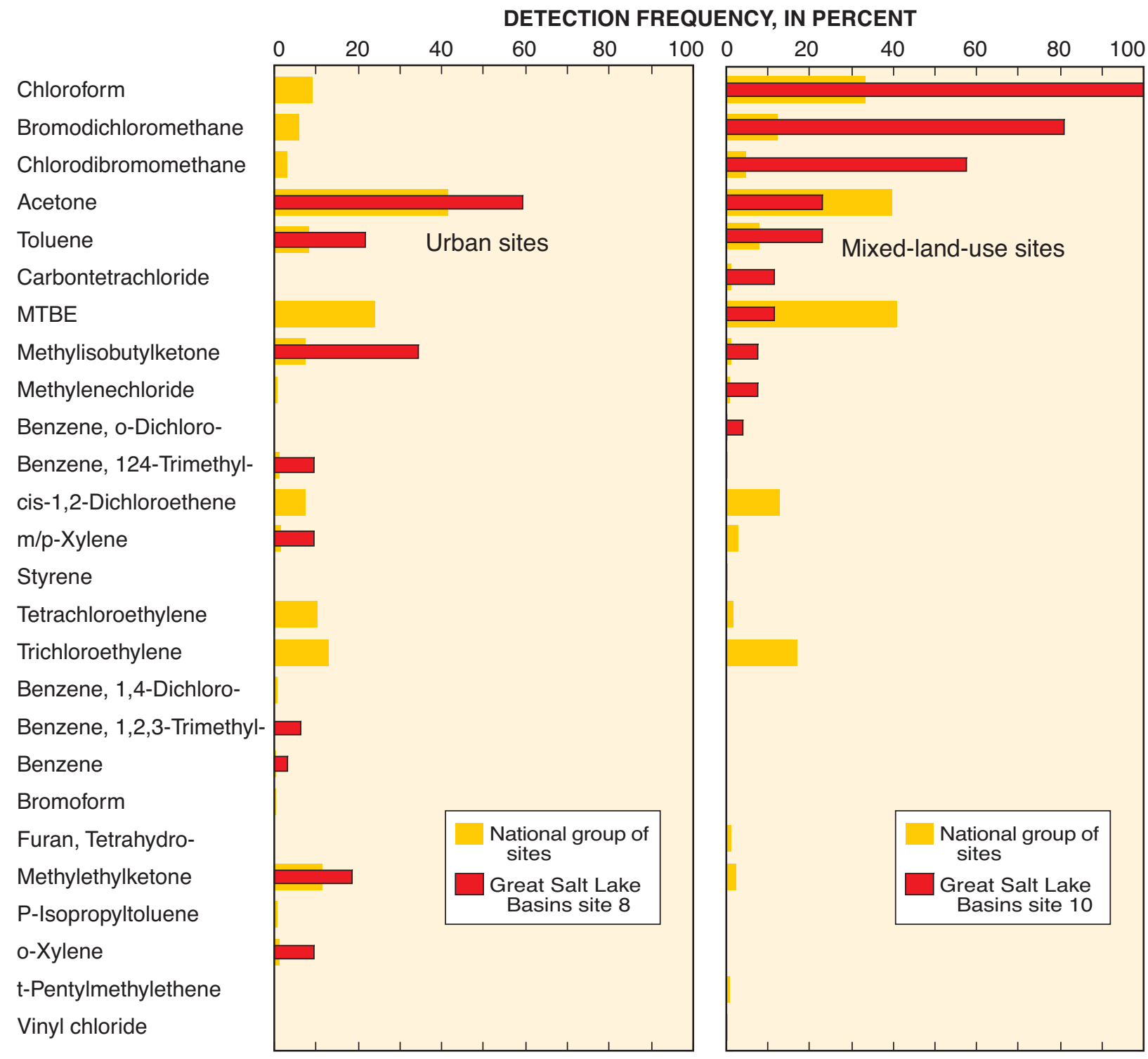

Figure 28. Detection frequency, based on a common reporting limit of 0.2 microgram per liter, of volatile organic compounds in water samples from urban and mixed-land-use sites in the Great Salt Lake Basins study unit and at sites with similar land uses in study units across the Nation, water years 1999-2000. 
Table 11. Summary of volatile organic compound concentrations detected in water samples from two sites in the Great Salt Lake Basins study unit

[ $\mu \mathrm{g} / \mathrm{L}$, micrograms per liter; $\geq$, greater than or equal to; AWQC, Ambient Water Quality Criteria for the protection of freshwater aquatic ecosystems; NR, not recorded; BTEX, benzene, toluene, ethylbenzene, and xylenes; DBP, disinfection by-product of chlorination (THMs); —, not established; nd, none detected; e, estimated; concentration in bold italics exceeds AWQC]

\begin{tabular}{|c|c|c|c|c|c|c|c|c|c|}
\hline \multirow{3}{*}{ Volatile organic compound } & \multirow{3}{*}{ Predominant use } & \multicolumn{8}{|c|}{ Site 8 (Little Cottonwood Creek at Jordan River) } \\
\hline & & \multicolumn{2}{|c|}{$\begin{array}{c}\text { Detections }^{1} \\
\text { (percent) }\end{array}$} & \multicolumn{6}{|c|}{$\begin{array}{c}\text { Concentration } \\
(\mu \mathrm{g} / \mathrm{L})\end{array}$} \\
\hline & & $\begin{array}{l}\text { Method } \\
\text { reporting } \\
\text { limit }\end{array}$ & $\begin{array}{c}\text { Common } \\
\text { reporting } \\
\text { limit } \\
(\geq 0.2 \mu \mathrm{g} / \mathrm{L})\end{array}$ & Minimı & & Media & & Maximu & \\
\hline $1,1,1$-Trichloroethane & solvent & 0.0 & 0.0 & nd & & nd & & nd & \\
\hline 1,2,3,4-Tetramethylbenzene & NR & 0 & 0 & nd & & nd & & nd & \\
\hline 1,2,3-Trimethylbenzene & NR & 12.5 & 0 & .008 & $\mathrm{e}$ & .153 & $\mathrm{e}$ & .168 & $\mathrm{e}$ \\
\hline 1,2,4-Trimethylbenzene & gasoline-related hydrocarbon & 59.4 & 9.4 & .008 & $\mathrm{e}$ & .025 & $\mathrm{e}$ & .662 & $\mathrm{e}$ \\
\hline 1,3,5-Trimethylbenzene & NR & 9.4 & 0 & .106 & $\mathrm{e}$ & .148 & $\mathrm{e}$ & .172 & $\mathrm{e}$ \\
\hline 1,4-Dichlorobenzene & fumigant & 6.3 & 0 & .008 & $\mathrm{e}$ & .027 & $\mathrm{e}$ & .046 & $\mathrm{e}$ \\
\hline Acetone & solvent & 59.4 & 59.4 & 1.11 & $\mathrm{e}$ & 3.52 & $\mathrm{e}$ & 20.0 & $\mathrm{e}$ \\
\hline Benzene & BTEX & 84.4 & 3.1 & .013 & $\mathrm{e}$ & .031 & $\mathrm{e}$ & .212 & $\mathrm{e}$ \\
\hline Bromodichloromethane & DBP & 6.3 & 0 & .013 & $\mathrm{e}$ & .014 & $\mathrm{e}$ & .016 & $\mathrm{e}$ \\
\hline Bromoform & DBP & 6.3 & 0 & .132 & & .144 & & .156 & \\
\hline Carbon disulfide & NR & 9.4 & 0 & .016 & $\mathrm{e}$ & .076 & $\mathrm{e}$ & .084 & $\mathrm{e}$ \\
\hline Carbontetrachloride & solvent & 0 & 0 & nd & & nd & & nd & \\
\hline Chlorobenzene & solvent & 0 & 0 & nd & & nd & & nd & \\
\hline Chlorodibromomethane & DBP & 0 & 0 & nd & & nd & & nd & \\
\hline Chloroform & DBP & 90.6 & 0 & .011 & $\mathrm{e}$ & .023 & $\mathrm{e}$ & .144 & $\mathrm{e}$ \\
\hline cis-1,2-Dichloroethene & solvent & 28.1 & 0 & .008 & $\mathrm{e}$ & .021 & $\mathrm{e}$ & .037 & $\mathrm{e}$ \\
\hline Ethylbenzene & BTEX & 62.5 & 0 & .004 & $\mathrm{e}$ & .012 & e & .132 & $\mathrm{e}$ \\
\hline Ethyl-ether & NR & 0 & 0 & nd & & nd & & nd & \\
\hline Isodurene & NR & 9.4 & 0 & .100 & $\mathrm{e}$ & .125 & $\mathrm{e}$ & .135 & $\mathrm{e}$ \\
\hline $\mathrm{m} / \mathrm{p}$ Xylene & BTEX & 75.0 & 9.4 & .010 & $\mathrm{e}$ & .041 & $\mathrm{e}$ & .692 & \\
\hline Methyl tert-butyl ether (MTBE) & oxygenate & 40.6 & 0 & .027 & $\mathrm{e}$ & .043 & e & .075 & $\mathrm{e}$ \\
\hline Methylchloride & solvent & 9.4 & 0 & .053 & $\mathrm{e}$ & .055 & e & .061 & e \\
\hline Methylene chloride & solvent & 37.5 & 0 & .013 & $\mathrm{e}$ & .021 & e & .038 & $\mathrm{e}$ \\
\hline Methylethylketone & NR & 34.4 & 34.4 & .509 & $\mathrm{e}$ & 1.04 & $\mathrm{e}$ & 3.03 & $\mathrm{e}$ \\
\hline Methylisobutylketone & NR & 37.5 & 34.4 & .144 & $\mathrm{e}$ & .884 & $\mathrm{e}$ & 1.48 & $\mathrm{e}$ \\
\hline n-Butylbenzene & gasoline-related hydrocarbon & 9.4 & 0 & .014 & $\mathrm{e}$ & .014 & e & .014 & $\mathrm{e}$ \\
\hline n-Propylbenzene & solvent & 9.4 & 0 & .025 & $\mathrm{e}$ & .049 & e & .052 & $\mathrm{e}$ \\
\hline o-Dichlorobenzene & solvent & 0 & 0 & nd & & nd & & nd & \\
\hline o-Ethyl-toluene & NR & 9.4 & 0 & .072 & $\mathrm{e}$ & .091 & $\mathrm{e}$ & .100 & $\mathrm{e}$ \\
\hline o-Xylene & BTEX & 59.4 & 9.4 & .012 & $\mathrm{e}$ & .022 & $\mathrm{e}$ & .355 & \\
\hline p-Isopropyltoluene & NR & 37.5 & 0 & .004 & $\mathrm{e}$ & .015 & e & .107 & $\mathrm{e}$ \\
\hline Styrene & gasoline-related hydrocarbon & 40.6 & 0 & .003 & $\mathrm{e}$ & .025 & e & .103 & \\
\hline Tetrachloroethylene & solvent & 46.9 & 0 & .006 & $\mathrm{e}$ & .012 & e & .082 & $\mathrm{e}$ \\
\hline Toluene & BTEX & 100 & 21.9 & .039 & $\mathrm{e}$ & .115 & & 3.15 & \\
\hline Trichloroethylene & solvent & 21.9 & 0 & .013 & $\mathrm{e}$ & .036 & e & .071 & $\mathrm{e}$ \\
\hline
\end{tabular}

${ }^{1}$ Percent detections per 32 samples.

${ }^{2}$ Percent detections per 26 samples.

${ }^{3}$ U.S. Environmental Protection Agency, 2002.

${ }^{4} \mathrm{EPA}$ freshwater aquatic-life acute criteria/guidelines (Rowe and others, 1997).

${ }^{5}$ Canadian Government aquatic-life guidelines (Canadian Council of Ministers of the Environment, 2001).

${ }^{6} \mathrm{EPA}$ freshwater aquatic-life chronic criteria/guidelines (Rowe and others, 1997). 
Table 11. Summary of volatile organic compound concentrations detected in water samples from two fixed sampling sites in the Great Salt Lake Basins study unit - Continued

\begin{tabular}{|c|c|c|c|c|c|c|c|c|c|c|}
\hline \multirow{3}{*}{ Volatile organic compound } & \multicolumn{8}{|c|}{ Site 10 (Jordan River at Salt Lake City) } & \multirow{3}{*}{$\begin{array}{c}\text { Human } \\
\text { health } \\
\text { guideline }^{3}\end{array}$} & \multirow{3}{*}{ AWOC } \\
\hline & \multicolumn{2}{|c|}{$\begin{array}{c}\text { Detections }^{2} \\
\text { (percent) }\end{array}$} & \multicolumn{6}{|c|}{$\begin{array}{c}\text { Concentration } \\
(\mu \mathrm{g} / \mathrm{L})\end{array}$} & & \\
\hline & $\begin{array}{l}\text { Method } \\
\text { reporting } \\
\text { limit }\end{array}$ & $\begin{array}{c}\text { Common } \\
\text { reporting } \\
\text { limit } \\
(\geq 0.2 \mu \mathrm{g} / \mathrm{L})\end{array}$ & Minimı & & Media & & Maximı & & & \\
\hline 1,1,1-Trichloroethane & 3.8 & 0.0 & 0.131 & $\mathrm{e}$ & 0.131 & $\mathrm{e}$ & 0.131 & $\mathrm{e}$ & 200 & ${ }^{5} 18,000$ \\
\hline 1,2,3,4-Tetramethylbenzene & 3.8 & 0 & .045 & $\mathrm{e}$ & .045 & $\mathrm{e}$ & .045 & $\mathrm{e}$ & - & - \\
\hline 1,2,3-Trimethylbenzene & 7.7 & 0 & .017 & $\mathrm{e}$ & .023 & $\mathrm{e}$ & .029 & $\mathrm{e}$ & - & - \\
\hline 1,2,4-Trimethylbenzene & 23.1 & 0 & .017 & e & .033 & $\mathrm{e}$ & .106 & $\mathrm{e}$ & - & - \\
\hline 1,3,5-Trimethylbenzene & 7.7 & 0 & .016 & $\mathrm{e}$ & .024 & $\mathrm{e}$ & .032 & $\mathrm{e}$ & - & - \\
\hline 1,4-Dichlorobenzene & 34.6 & 0 & .006 & $\mathrm{e}$ & .016 & $\mathrm{e}$ & .022 & $\mathrm{e}$ & 75 & $5_{26}$ \\
\hline Acetone & 23.1 & 23.1 & 1.60 & $\mathrm{e}$ & 2.00 & $\mathrm{e}$ & 4.47 & $\mathrm{e}$ & - & - \\
\hline Benzene & 84.6 & 0 & .011 & $\mathrm{e}$ & .019 & $\mathrm{e}$ & .040 & $\mathrm{e}$ & - & $5_{370}$ \\
\hline Bromodichloromethane & 100 & 80.8 & .113 & & .399 & & 1.96 & & 80 & ${ }^{4} 11,000$ \\
\hline Bromoform & 23.1 & 0 & .028 & $\mathrm{e}$ & .080 & $\mathrm{e}$ & .105 & $\mathrm{e}$ & 80 & ${ }^{4} 11,000$ \\
\hline Carbon disulfide & 53.8 & 0 & .017 & $\mathrm{e}$ & .030 & $\mathrm{e}$ & .048 & $\mathrm{e}$ & - & ${ }^{6} 2$ \\
\hline Carbontetrachloride & 30.8 & 11.5 & .016 & $\mathrm{e}$ & .040 & $\mathrm{e}$ & .402 & $\mathrm{e}$ & 5 & ${ }^{5} 13.3$ \\
\hline Chlorobenzene & 3.8 & 0 & .010 & $\mathrm{e}$ & .010 & $\mathrm{e}$ & .010 & $\mathrm{e}$ & 100 & ${ }^{5} 1.3$ \\
\hline Chlorodibromomethane & 100 & 42.3 & .040 & $\mathrm{e}$ & .183 & & .992 & & 80 & ${ }^{4} 11,000$ \\
\hline Chloroform & 100 & 100 & .250 & & .812 & & 3.99 & & 80 & ${ }^{5} 1.8$ \\
\hline cis-1,2-Dichloroethene & 53.8 & 0 & .009 & $\mathrm{e}$ & .013 & $\mathrm{e}$ & .035 & $\mathrm{e}$ & 70 & ${ }^{4} 11,600$ \\
\hline Ethylbenzene & 19.2 & 0 & .005 & $\mathrm{e}$ & .013 & $\mathrm{e}$ & .044 & $\mathrm{e}$ & 700 & $5_{90}$ \\
\hline Ethyl-ether & 7.7 & 0 & .019 & $\mathrm{e}$ & .043 & $\mathrm{e}$ & .067 & $\mathrm{e}$ & - & - \\
\hline Isodurene & 0 & 0 & nd & & nd & & nd & & - & - \\
\hline $\mathrm{m} / \mathrm{p}$ Xylene & 50.0 & 0 & .017 & $\mathrm{e}$ & .025 & $\mathrm{e}$ & .177 & $\mathrm{e}$ & 10,000 & - \\
\hline Methyl tert-butyl ether (MTBE) & 69.2 & 11.5 & .038 & $\mathrm{e}$ & .069 & $\mathrm{e}$ & .416 & & 20 & - \\
\hline Methylchloride & 11.5 & 0 & .040 & $\mathrm{e}$ & .070 & $\mathrm{e}$ & .081 & & 30 & - \\
\hline Methylene chloride & 69.2 & 0 & .013 & $\mathrm{e}$ & .033 & $\mathrm{e}$ & .186 & $\mathrm{e}$ & 5 & ${ }^{5} 98.1$ \\
\hline Methylethylketone & 3.8 & 3.8 & .542 & $\mathrm{e}$ & .542 & $\mathrm{e}$ & .542 & $\mathrm{e}$ & - & - \\
\hline Methylisobutylketone & 7.7 & 3.8 & .166 & $\mathrm{e}$ & .190 & $\mathrm{e}$ & .214 & $\mathrm{e}$ & - & - \\
\hline n-Butylbenzene & 0 & 0 & nd & & nd & & nd & & - & - \\
\hline n-Propylbenzene & 3.8 & 0 & .013 & $\mathrm{e}$ & .013 & $\mathrm{e}$ & .013 & $\mathrm{e}$ & - & - \\
\hline o-Dichlorobenzene & 3.8 & 3.8 & .365 & & .365 & & .365 & & - & - \\
\hline o-Ethyl-toluene & 3.8 & 0 & .021 & $\mathrm{e}$ & .021 & $\mathrm{e}$ & .021 & $\mathrm{e}$ & - & - \\
\hline o-Xylene & 26.9 & 0 & .010 & $\mathrm{e}$ & .015 & $\mathrm{e}$ & .084 & $\mathrm{e}$ & 10,000 & - \\
\hline p-Isopropyltoluene & 3.8 & 0 & .011 & $\mathrm{e}$ & .011 & $\mathrm{e}$ & .011 & $\mathrm{e}$ & - & - \\
\hline Styrene & 34.6 & 0 & .004 & $\mathrm{e}$ & .007 & $\mathrm{e}$ & .017 & $\mathrm{e}$ & - & 472 \\
\hline Tetrachloroethylene & 96.2 & 0 & .014 & $\mathrm{e}$ & .033 & $\mathrm{e}$ & .103 & & 5 & ${ }^{4} 111$ \\
\hline Toluene & 100 & 23.1 & .033 & $\mathrm{e}$ & .081 & $\mathrm{e}$ & .829 & & 1,000 & ${ }^{4} 2$ \\
\hline Trichloroethylene & 42.3 & 0 & .008 & $\mathrm{e}$ & .018 & $\mathrm{e}$ & .039 & $\mathrm{e}$ & 5 & ${ }^{4} 21$ \\
\hline
\end{tabular}


90th-PERCENTILE CONCENTRATION, IN MICROGRAMS PER LITER

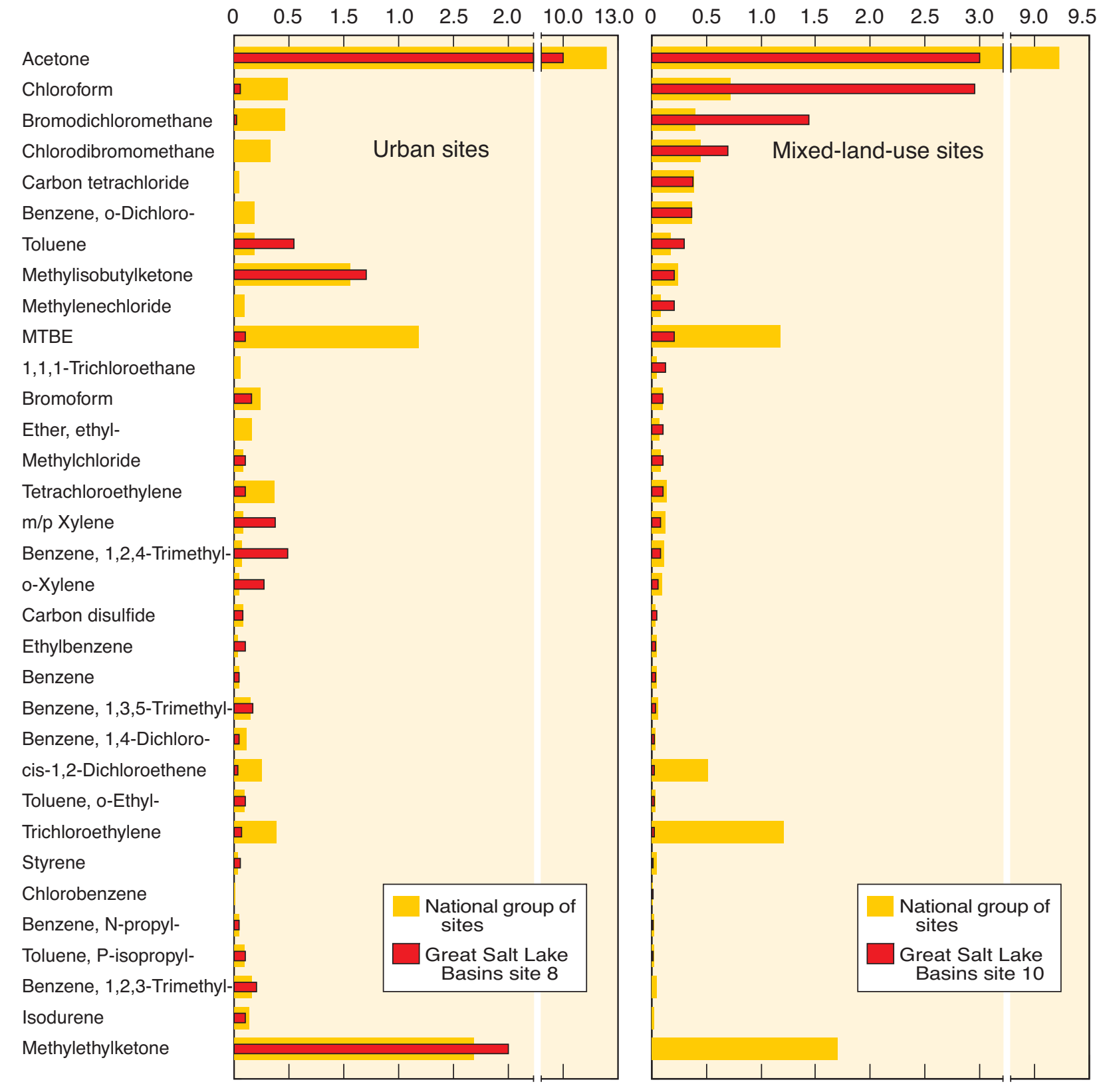

Figure 29. Ninetieth-percentile concentration of volatile organic compounds detected in water samples from urban and mixed-land-use sites in the Great Salt Lake Basins study unit and at sites with similar land uses in study units across the Nation, water years 1999-2000. 


\section{Organic Carbon}

Dissolved organic carbon concentrations in water samples from the sites ranged from 0.7 to 16 $\mathrm{mg} / \mathrm{L}$ (fig. 30). The highest concentrations of dissolved organic carbon were detected in water samples collected from Little Cottonwood Creek when spring storm runoff was a large component of streamflow. Dissolved organic carbon concentration in nonstorm samples generally was higher at site 8 than at site 7 , indicating that runoff from urban areas is a source of dissolved organic carbon for Little Cottonwood Creek. Dissolved organic carbon concentrations were lowest in samples from Red Butte Creek. The median dissolved organic carbon concentration at most sites was between 2 and $4 \mathrm{mg} / \mathrm{L}$. Dissolved organic carbon was slightly enriched in the Bear River as it was diverted through Mud Lake and resulted in generally higher concentrations at site 2 relative to site 1 . Chlorinating water that contains dissolved organic carbon can result in the formation of THMs, which could become a water-quality issue if additional municipal water supplies are developed from the Bear River.

\section{SUMMARY}

The Great Salt Lake Basins (GRSL) study unit is 1 of 51 study units that are included in the National Water-Quality Assessment (NAWQA) program. A group of 15 study units, including the GRSL, began in 1997. The GRSL study unit encompasses three major river systems that enter Great Salt Lake: the Bear, the Weber, and the Utah Lake/Jordan River systems. Most of the $14,500 \mathrm{mi}^{2}$ of the GRSL study unit is in Utah, but areas in Idaho and Wyoming also are included. The study unit includes Utah's largest cities (the Salt Lake City, Ogden, and Provo metropolitan areas) and about 1.9 million people.

A fixed-site assessment was used to assess the spatial and seasonal distribution of selected constituents. Sites were chosen to represent specific environmental settings, such as agricultural land or urban land, or to represent integration of multiple land uses. Ten sites were selected in the GRSL for the NAWQA program and were sampled during water years 1999-2000.

Annual runoff at all fixed sites during water year 1999 exceeded the long-term average for those sites. Water year 2000 was a very dry year in the GRSL study unit, with 8 of 12 months having less-than-average precipitation. Runoff during water year 2000 at most sites was less than the average annual runoff for those sites.

Median dissolved-solids concentrations were highest at mixed-land-use fixed sites. Dissolved-solids concentration was highest at most sites during July to October, when water with lower dissolved-solids concentration is removed at upstream diversions and irrigation return is a major component of streamflow.

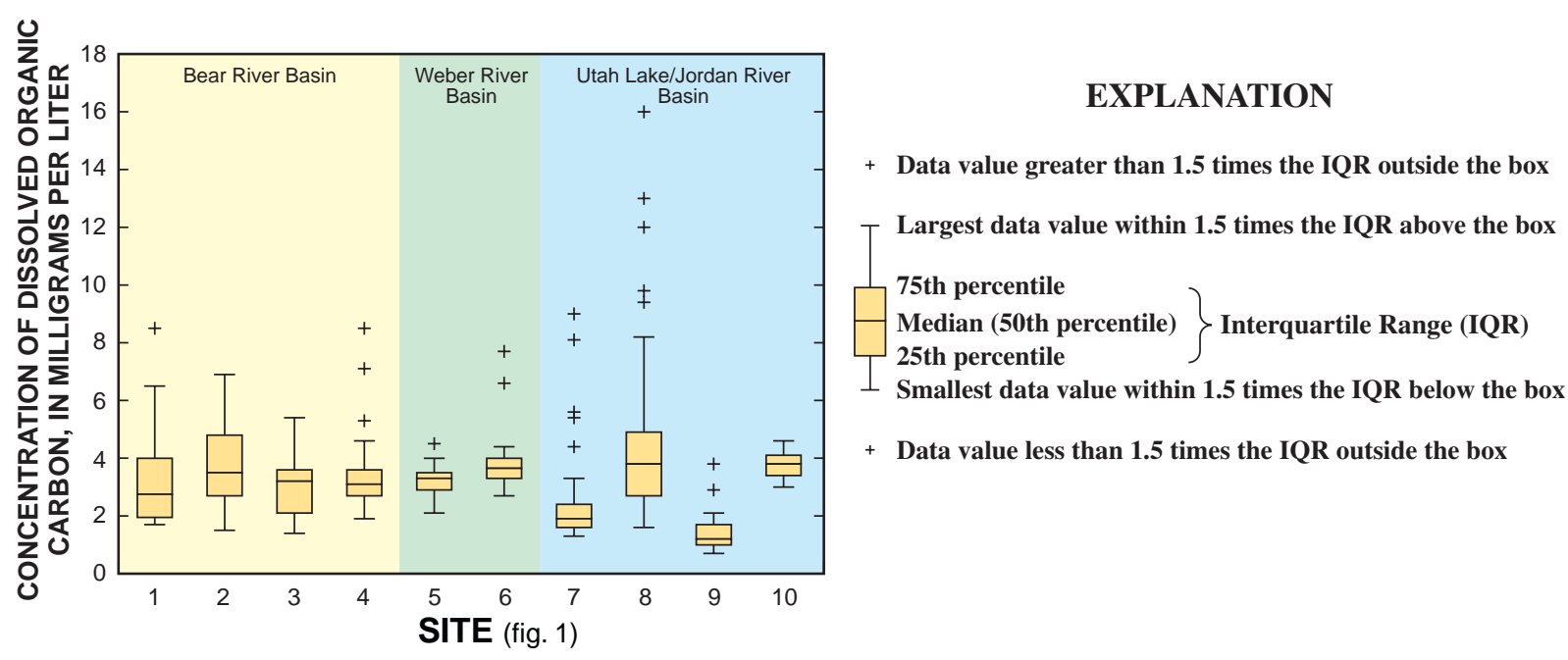

Figure 30. Dissolved oganic carbon concentration in water samples from fixed sites in the Great Salt Lake Basins study unit. 
Water samples analyzed for dissolved-solids concentration show that water at GRSL sites generally is acceptable for agricultural uses, except possibly in sections of the Bear River during low streamflows.

Seasonal patterns in total-nitrogen concentration were evident at most sites. Total-nitrogen concentration increased at most sites during periods of base flow when streamflow was low, ground water or treated waste water was the primary streamflow component, and nutrient uptake by aquatic vegetation was reduced. Nitrite plus nitrate concentration was highest at sites with runoff from agricultural land and sites with more urban land cover. None of the samples from the GRSL sites had nitrate concentrations above the U.S. Environmental Protection Agency drinking-water standard of $10 \mathrm{mg} / \mathrm{L}$. The maximum nitrate concentration was $6.54 \mathrm{mg} / \mathrm{L}$ at Jordan River at Salt Lake City (site 10). The Utah Department of Environmental Quality designates a concentration of nitrate above $4.0 \mathrm{mg} / \mathrm{L}$ as an indicator of pollution. This level was exceeded three times at site 10, the Jordan River at Salt Lake City, but no other sites had nitrate concentrations that exceeded this level.

Orthophosphate concentrations were elevated at sites with mixed land use, probably as a result of a higher percentage of treated waste water in streamflow at these sites. The maximum total phosphorus concentration at the GRSL sites was $2.39 \mathrm{mg} / \mathrm{L}$ at Little Cottonwood Creek at Jordan River (site 8), which was associated with storm runoff. The median total phosphorus concentration at several sites exceeded $0.10 \mathrm{mg} / \mathrm{L}$, indicating that the potential for eutrophication exists.

Sites in the Bear River drainage basin had the highest median concentrations of suspended sediment, ranging from 68 to $110 \mathrm{mg} / \mathrm{L}$. Water samples collected at Little Cottonwood Creek at Jordan River (site 8) had a median suspended-sediment concentration of 36 $\mathrm{mg} / \mathrm{L}$; however, samples collected when a large component of streamflow was storm runoff from urban land had concentrations as high as 1,580 mg/L.

Beryllium, cadmium, cobalt, and silver were not detected in water samples from GRSL sites above the minimum reporting level of $1 \mu \mathrm{g} / \mathrm{L}$. Boron, molybdenum, and strontium concentrations were enriched in samples from urban sites. Chromium, lead, nickel, and zinc were detected in some samples, but concentrations did not exceed the Ambient Water Quality Criteria (AWQC) established for those elements. Arsenic was detected in 127 of 139 water samples. It was detected in all 49 water samples collected from Little Cottonwood Creek at Jordan River (site 8) and exceeded the AWQC of $150 \mu \mathrm{g} / \mathrm{L}$ in 8 samples. Copper was detected in 116 of 134 water samples from GRSL sites in concentrations from 0.9 to $5.7 \mu \mathrm{g} / \mathrm{L}$. The AWQC for copper was exceeded twice at Little Cottonwood Creek at Crestwood Park (site 7). The maximum concentration of selenium in samples was $6.0 \mu \mathrm{g} / \mathrm{L}$. Selenium concentrations generally were low, but two samples from Little Cottonwood Creek at Jordan River (site 8) exceeded the AWQC of $4.6 \mu \mathrm{g} / \mathrm{L}$ (for dissolved selenium).

Forty-three of the 107 pesticides analyzed for in water samples from GRSL sites were detected: 21 at Cub River near Richmond (site 3), an agricultural site; 32 at Little Cottonwood Creek at Jordan River (site 8), an urban site; and 33 at Jordan River at Salt Lake City (site 10), a mixed-land-use site. Thirty-one of the pesticides detected were herbicides, 4 were herbicide metabolites, 7 were insecticides, and 1 was a fungicide. The herbicides atrazine and prometon, and the insecticides carbaryl and diazinon were the most frequently detected pesticides. Carbaryl concentration exceeded the AWQC of $0.2 \mu \mathrm{g} / \mathrm{L}$ four times and diazinon concentration exceeded the AWQC of 0.08 $\mu \mathrm{g} / \mathrm{L}$ eight times. Malathion concentration exceeded the AWQC of $0.1 \mu \mathrm{g} / \mathrm{L}$ twice.

Thirty-five of the 86 volatile organic compounds (VOCs) analyzed for in water samples from GRSL sites were detected: 28 in samples from Little Cottonwood Creek at Jordan River (site 8) and 33 in samples from Jordan River at Salt Lake City (site 10). All VOC samples had at least two VOCs detected. In water samples from the GRSL sites most VOC concentrations were less than $1 \mu \mathrm{g} / \mathrm{L}$; however, concentrations of acetone, bromodichloromethane, chloroform, methylethylketone, methylisobutylketone, and toluene, exceeded $1 \mu \mathrm{g} / \mathrm{L}$ in some samples. Chloroform and toluene were detected in more than 90 percent of the water samples and were the most frequently detected VOCs. Trihalomethanes (bromoform, bromodichloromethane, chloroform, and chlorodibromomethane) and fuel-related BTEX compounds (benzene, toluene, ethyl benzene, and the xylenes) were the most frequently detected groups of VOCs. Toluene exceeded the AWQC of $2 \mu \mathrm{g} / \mathrm{L}$ in one sample. 


\section{REFERENCES CITED}

Anderson, J.R., Hardy, E.E., Roach, J.T., and Witmer, R.E., 1976, A land use and land cover classification system for use with remote sensor data: U.S. Geological Survey Professional Paper 964, 28 p.

Baskin, R.L., Thiros, S.A., Giddings, E.M., Hadley, H.K., Gerner, S.J., Stephens, D.W., and Waddell, K.M., 2002, Water-quality assessment of the Great Salt Lake Basins, Utah, Idaho, and Wyoming-Environmental setting and study design: U.S. Geological Survey Water-Resources Investigations Report 02-4115, 47 p.

Canadian Council of Ministers of the Environment, 2001, Canadian water quality guidelines for the protection of aquatic life: Summary table, accessed June 27, 2001, at URL http://www.ec.gc.ca/ceqg-rcqe

Capel, P.D., Spexet, A.H., and Larson, S.J., 1999, Occurrence and behavior of the herbicide prometon in the hydrologic system, 1999: Environmental Science and Technology, v. 33, no. 5, p. 674-680.

Clark, G.M., Mueller, D.K., and Mast, M.A., 2000, Nutrient concentrations and yields in undeveloped stream basins of the United States: Journal of the American Water Resources Association, v. 36, no. 4, p. 849-860.

Deer, H., and Roe, A.H., 1997, Pesticide use on Utah's small grain crops, accessed May 1, 2002, at URL http://extension.usu.edu/coop/ag/environ/upep/survey/SGSURVEY.HTM

Desert Research Institute, Western Region Climate Center, 2002, Utah Climate Summaries: accessed August 30, 2002, at URL http://www.wrcc.dri.edu/summary/climsmut.html

Dover, J.H., 1987, Geologic map of the Mount Naomi roadless area, Cache County, Utah, and Franklin County, Idaho: U.S. Geological Survey Miscellaneous Field Studies Map MF-1566-B, scale 1:100,000.

Fenneman, N.M., 1931, Physiography of the western United States: New York, McGraw-Hill, 534 p.

Gerner, S.J., and Waddell, K.M., 2003, Hydrology and water quality of an urban stream reach in the Great BasinLittle Cottonwood Creek near Salt Lake City, Utah, Water Years 1999-2000: U.S. Geological Survey WaterResources Investigations Report 02-4276, 46 p.

Giddings, E.M., Hornberger, M.I., and Hadley, H.K., 2001, Trace-metal concentrations in sediment and water and health of aquatic macroinvertebrate communities of streams near Park City, Summit County, Utah: U.S. Geological Survey Water-Resources Investigations Report 01-4213, 22 p.

Gilliom, R.J., Alley, W.M., and Gurtz, M.E., 1995, Design of the National Water-Quality Assessment Program: Occurrence and distribution of water-quality conditions: U.S. Geological Survey Circular 1112, 33 p.
Hem, J.D., 1992, Study and interpretation of chemical characteristics of natural water: U.S. Geological Survey Water-Supply Paper 2254, 263 p.

Herbert, L.R., Allen, D.V., Wilberg, D.E., and Tibbets, J.R., 2000, Water Resources Data, Utah, Water Year 1999: U.S. Geological Survey Water-Data Reports UT-99-1, $340 \mathrm{p}$.

Herbert, L.R., Wilberg, D.E., Tibbets, J.R., and Allen, D.V, 2001, Water Resources Data, Utah, Water Year 2000: U.S. Geological Survey Water-Data Reports UT-00-1, $380 \mathrm{p}$.

Herbert, L.R., Wilberg, D.E., and Tibbets, J.R., 2002,Water Resources Data, Utah, Water Year 2001: U.S. Geological Survey Water-Data Reports UT-01-1, 440 p.

International Joint Commission United States and Canada, 1989, Revised Great Lakes water quality agreement of 1978, agreement, with annexes and terms of reference, between the United States and Canada signed at Ottawa November 22, 1978, and phosphorus load reduction supplement signed October 16, 1983, as amended by Protocol signed November 18, 1987, accessed on April 15, 2000, at URL http://www.ijc.org/agree/quality.html\#art5

Larson, S.J., Capel, P.D., and Majewski, M.S., 1997, Pesticides in surface waters-Distribution, trends, and governing factors: Chelsea, Mich., Ann Arbor Press, 373 p.

Mast, M.A., and Clow, D.W., 2000, Environmental characteristics and water quality of Hydrologic Benchmark Network stations in the Western United States: U.S. Geological Survey Circular 1173-D, 115 p.

Mueller, D.K., Martin, J.D., and Lopes, T.J., 1997, Qualitycontrol design for surface-water sampling in the National Water-Quality Assessment Program: U.S. Geological Survey Open-File Report 97-223, 17 p.

Rowe, B.L., Landrigan, S.J., Lopes, T.J., 1997, Summary of published aquatic toxicity information and water-quality criteria for selected volatile organic compounds: U.S. Geological Survey Open-File Report 97-563, 12 p.

Shelton, L.R., 1994, Field guide for collecting and processing stream-water samples for the National Water-Quality Assessment Program: U.S. Geological Survey Open-File Report 94-455, 42 p.

1997, Field guide for collecting samples for analysis of volatile organic compounds in stream water for the National Water-Quality Assessment Program: U.S. Geological Survey Open-File Report 97-401, 14 p.

Thiros, S.A., 2000, Analysis of nitrate and volatile organic compound data for ground water in the Great Salt Lake Basins, Utah, Idaho, and Wyoming, 1980-98, National Water-Quality Assessment Program: U.S. Geological Survey Water-Resources Investigations Report 004043, 20 p. 
U.S. Environmental Protection Agency, 1986, Quality criteria for water-1986: U.S. Environmental Protection Agency Report EPA 440/5-86-001, 453 p.

1998, National strategy for the development of regional nutrient criteria: U.S. Environmental Protection Agency Report EPA 822-R-98-002, 52 p. 1999a, National recommended water quality criteria-correction: U.S. Environmental Protection Agency Report EPA 822-Z-99-002, accessed May 21, 2001, at URL http://www.epa.gov/OST/standards/wqcriteria.html

1999b, Update of ambient water quality criteria for ammonia: U.S. Environmental Protection Agency Report EPA 822-R-99-014, accessed May 29, 2002, at URL http://www.epa.gov/waterscience/standards/ammonia/99update.pdf

2000, Level III ecoregions of the continental United States (revision of Omernik, 1987): U.S. Environmental Protection Agency Report, National Health and Environmental Research Laboratory, Map M-1, various scales.

-2002, 2002 edition of the drinking water standards and health advisories: U.S. Environmental Protection Agency Report EPA 822-R-02-038, accessed May 19, 2003, at http://www.epa.gov/OST/drinking/standards
Utah Department of Administrative Services, 2003, Utah Administrative Code R317-2 (through February 1, 2003): Division of Administrative Rules, Salt Lake City, Utah, accessed May 19, 2003, at URL http://www.rules.utah.gov/publicat/code.htm

Utah Department of Environmental Quality, 2002a, Utah Water Quality Assessment Report to Congress 2002: Division of Water Quality, Salt Lake City, Utah, variously paged.

2002b, Utah's 2002 303(d) List of Waters: Division of Water Quality, Salt Lake City, Utah, 94 p.

Utah Department of Natural Resources, 1997a, Utah State Water Plan-Jordan River basin: Division of Water Resources, Salt Lake City, Utah, variously paged.

-1997b, Utah State Water Plan_Weber River basin: Division of Water Resources, Salt Lake City, Utah, variously paged.

Waddell, K.M., and Barton, J.D., 1980, Estimated inflow and evaporation for Great Salt Lake, Utah, 1931-76, with revised model for evaluating the effects of dikes on the water and salt balance of the lake: Utah Department of Natural Resources, Division of Water Resources Cooperative Investigation Report Number 20, 57 p.

Woods, A.J., Lammers, D.A., Bryce, S.A., Omernik, J.M., Denton, R.L., Domeier, M., and Comstock, J.A., 2001, Ecoregions of Utah (color poster with map, descriptive text, summary tables, and photographs): Reston, Virginia, U.S. Geological Survey (map scale 1:1,175,000). 